\title{
ALTERAÇÕES METABÓLICAS EM RATOS DESNUTRIDOS EM RESPOSTA AO TREINAMENTO DE ENDURANCE
}

\author{
Marcus Vinícius Giampietro
}

São Paulo

2007 


\title{
ALTERAÇÕES METABÓLICAS EM RATOS DESNUTRIDOS EM RESPOSTA AO TREINAMENTO DE ENDURANCE
}

\author{
Marcus Vinícius Giampietro
}

Dissertação apresentada ao Instituto de Ciências Biomédicas da Universidade de São Paulo para obtenção do Título de Mestre em Ciências.

São Paulo

2007 


\title{
ALTERAÇÕES METABÓLICAS EM RATOS DESNUTRIDOS EM RESPOSTA AO TREINAMENTO DE ENDURANCE
}

\author{
Marcus Vinícius Giampietro
}

Dissertação apresentada ao Instituto de Ciências Biomédicas da Universidade de São Paulo para obtenção do Título de Mestre em Ciências.

Área de Concentração:

Biologia Celular e Tecidual

Orientadora:

Prof $^{\text {a. }}$ Dr $^{\text {a. }}$ Marília Cerqueira Leite Seelaender

São Paulo

2007 
DEDICATÓRIA

Ao GG (in memorian), uma pessoa incrível, um professor para a vida, um amigo para sempre... 


\section{AGRADECIMENTOS}

À minha orientadora, Marília, que me acolheu num momento difícil em nossas vidas e me orientou com maestria, paciência e generosidade, me dando a oportunidade e confiança de continuar meu projeto em seu laboratório.

À minha família, principalmente, meus pais, que em todos os momentos me apoiaram e, por toda a minha vida me incentivaram ferrenhamente a sempre estudar muito.

Ao GG (in memorian), meu amigo e orientador, que sempre me ensinou a ir em busca daquilo que mais desejamos e nunca desistir. Pela oportunidade, pela elaboração deste projeto em conjunto, e pelas discussões sempre polêmicas em nosso extinto Laboratório de Metabolismo. Por outros projetos paralelos e mirabolantes que sempre inspirou, incentivou e viabilizou a realizarmos. À visão geral e integrada das coisas que nos ensinou a enxergar. Por organizar um ambiente comuno-anárquico-sindicalista em nosso Laboratório. Pela companhia em treinos em que tive a oportunidade de passar horas ouvindo e aprendendo com suas histórias de vida.

À Nat, pelo amor dedicado a mim, pelo companheirismo e compreensão nos momentos difíceis. Pelos momentos divertidos no Laboratório de Metabolismo e pelas brigas que compramos juntos lá dentro. Pelos projetos mirabolantes que fizemos dar certo, apesar de toda a mão-de-obra, mas que nos divertiu muito e nos fez crescer. Também, aos almoços compartilhados.

Ao meu grande amigo Éricão, Érico Chagas Caperuto, por me levar ao laboratório onde tudo começou e agora finaliza com esta dissertação. Pela parceria em diversos trabalhos e projetos, por sempre estar disposto a ajudar e pelo incentivo em todos os momentos. Como um irmão, pelos conselhos para a profissão e para vida. E, pelos cafés...

À Ani e Fe, minhas amigas de Laboratório de Metabolismo, onde começamos juntos uma difícil caminhada para nossas carreiras e vidas, mas que sempre em que estávamos juntos à tornamos muito divertida e agradável. Aos almoços e cafés com muita filosofia e risadas.

À minha grande amiga Dani, que conheci depois de mudar para o Laboratório de Lípides, e vi se tornar uma amiga especial, sempre disposta a ajudar, muito pró-ativa e com pensamentos positivos, além de ser a razão de muitas risadas em nosso ambiente de trabalho. Obrigado por me iniciar no mundo da biologia molecular.

Ao Tubarão, um grande amigo que conheci aos poucos e aprendi a admirar. Obrigado pela força nos momentos difíceis, pela parceria em trabalhos, pelas palavras de apoio e, pela energia positiva que você libera no ambiente em que está presente e que sempre me contagia.

Aos colegas de laboratório que diretamente fizeram parte deste projeto: Wilton, Daniel Bob, Alex, Léo e Cida, onde dividimos muito trabalho e dores de cabeça, mas sempre com alegria e tranqüilidade.

A todos os colegas do extinto Laboratório de Metabolismo pelas discussões, pela ajuda constante e por tornar sempre divertido nosso ambiente de trabalho: Bob, Eivor, 
Marcela, Ronaldinho, Uchidão, Bia, Tubarão, Éricão, Wilton, Ani, Fe, Nat, Carol, Hélio Alex, Zeca, e todos que passaram pelo laboratório e fizeram daquele ambiente uma oportunidade única de, junto ao GG, conviver em uma comunidade comuno-anárquica-sindicalista.

Aos novos colegas de Laboratório de Lípides por nos acolher e permitir a bagunça em seu ambiente de trabalho, e pelas risadas compartilhadas: Fio, Luis, Bibi, Fabião, Michel, Renata. Desculpem pela invasão.

À Emília, pela constante ajuda e prontidão, pelo suporte técnico, e pelos conselhos.

Aos meus amigos que sempre me apoiaram em minhas escolhas, mesmo sem saber ao certo o que eu faço dentro de um laboratório com ratos.

Ao Cláudio, Nancy, Santa e Fernando, pela ajuda com os animais em nosso Biotério.

A todos os funcionários da biblioteca do ICB, que sempre facilitaram nosso trabalho na busca pelo conhecimento.

À Celiana, secretária do Departamento de Biologia Celular do ICB, sempre disposta a ajudar.

Aos funcionários do xerox, que sempre deram um jeitinho de nos atender melhor e mais rápido.

A todos os professores do ICB, que de alguma forma fizeram parte de nossa formação em debates, em disciplinas, no bar ou em um bate-papo no corredor.

Ao CNPq, pela bolsa de estudos, que tornou possível a realização desse projeto. 
"Você não precisa acertar sempre.

Mas não pode errar nunca.”

Brigadeiro Pamplona 


\section{RESUMO}

GIAMPIETRO, M.V. Alterações metabólicas em ratos desnutridos em resposta ao treinamento de endurance. 2007. 79 f. Dissertação (Mestrado em Ciências) - Instituto de Ciências Biomédicas, Universidade de São Paulo, São Paulo, 2007.

A desnutrição é capaz de induzir diversas alterações metabólicas afetando marcadamente a composição corporal. O exercício físico, por sua vez, produz alterações que podem ser semelhantes, porém, através de mecanismos distintos. A combinação dos protocolos não resulta, necessariamente, em somatório dos efeitos de cada um, induzindo, portanto, alterações ainda pouco conhecidas. Assim, esse trabalho teve como objetivo avaliar os efeitos do treinamento físico de endurance sobre ratos submetidos a um protocolo de desnutrição por um período prolongado de tempo. Para tal, avaliamos ratos Wistar machos, durante 16 semanas, divididos em 4 grupos: eutrófico sedentário (ES), eutrófico treinado (ET), desnutrido sedentário (DS), desnutrido treinado (DT). O treinamento físico foi realizado em esteira, por 10 semanas, 5 vezes por semana, com intensidade aproximada de $60-65 \%$ do consumo máximo de oxigênio. Avaliou-se a composição corporal, através da aferição do peso corporal, peso dos tecidos muscular esquelético e adiposo, do fígado, do conteúdo de gordura e da proteína na carcaça, da porcentagem de gordura e de massa magra; das concentrações de proteína, glicose e insulina no sangue; e da concentração de glicogênio muscular. Examinouse também a expressão gênica por RT-PCR de proteínas-chave do metabolismo glicolítico e oxidativo no músculo esquelético, o consumo máximo de oxigênio e o desempenho através de um teste até a exaustão. A análise estatística utilizada foi o teste de variância ANOVA twoway com pós teste de Tukey e, nível de significância adotado de $\mathrm{p}<0,05$. Os principais resultados encontrados foram que o treinamento de endurance em ratos submetidos à desnutrição crônica promoveu uma acentuada redução do peso e da adiposidade corporal; um aumento da massa muscular relativa ao peso corporal; um restabelecimento da glicemia aos valores normais; uma melhor relação da concentração insulina/glicose, sugerindo uma sensibilidade à insulina aumentada; um aumento dos estoques de glicogênio muscular; um maior consumo máximo de oxigênio; e um aumento da expressão gênica da enzima CPT II. Concluímos, desta forma que, todos esses resultados contribuíram para um melhor desempenho de endurance, e podem explicar, o melhor desempenho de corrida apresentado pelos animais desnutridos submetidos ao treinamento aeróbio. Em suma, os animais 
desnutridos treinados apresentaram uma melhor resposta ao treinamento e uma maior capacidade de endurance.

Palavras-chave: desnutrição, treinamento físico de endurance, metabolismo. 


\begin{abstract}
GIAMPIETRO, M.V. Metabolic alterations in undernourished rats submitted to an endurance training program. 2007. Master thesis (Sciences) - Institute of Biomedical Sciences, University of São Paulo, São Paulo, 2007.

Malnutrition is able to induce several metabolic alterations, markedly affecting body composition. Physical exercise induces alterations that may be similar, but not necessarily identical and through different mechanisms. Combining protocols does not result in the sum of effects, but induces alterations which are not, at present, fully understood. Our aim was to examine the effects of endurance training upon the metabolism of undernourished rats. For 16 weeks, male Wistar rats, divided into 4 groups: sedentary animals fed ad libitum (SF), trained animals fed ad libitum (TF), sedentary animals submitted to energy restriction (SER), trained animals submitted to energy restriction (TER) were studied. The trained animals exercised on a treadmill 5 days/week, for 10 weeks, with the intensity representing nearly $60-65 \% \mathrm{VO}_{2 \max }$. Body composition was assessed through the measurement of body weight, tissues and organ weight (muscular tissue, adipose tissue, liver), carcass lipid and protein content, percentage of lipid and lean body mass.Protein, glucose and insulin blood concentration; muscle glycogen concentration; maximum oxygen uptake; and the performance through the exhaustion test were also examined. The gene expression of glycolytic and oxidative pathways key proteins in the skeletal muscle was evaluated by RT-PCR. ANOVA two-way was the statistical analysis adopted followed by Tukey's post test, and $\mathrm{p}<0.05$ was chosen as the level of significance. The main results provided evidence that endurance training in undernourished rats (TER) promoted a pronounced reduction of body weight and adiposity, increased the relative muscle mass, recovered blood glucose to normal levels and promoted a better insulin/glucose ratio, suggesting increased insulin sensitivity, as well as induced an increase muscle glycogen content and enhanced $\mathrm{VO}_{2 \max }$. An increased gene expression of carnitine palmitoyltransferase II (CPT II) was also observed. We conclude that the results indicate that the combination of exercise and undernourishment led to a better performance.
\end{abstract}

Key-words: malnutrition, endurance training, metabolism. 


\section{ABREVIATURAS}

ADP: adenosina difosfato

AMP: adenosina monofosfato

ATP: adenosina trifosfato

CAT: acilcarnitina carnitina translocase

cDNA: DNA complementar

$\mathrm{CO}_{2}$ : dióxido de carbono

CPT I: carnitina palmitoiltransferase um

CPT II: carnitina palmitoiltransferase dois

CPT: carnitina palmitoiltransferase

CS: citrato sintase

DEPC: dietilpirocarbonato

DNA: ácido desoxirribonucléico

DS: grupo de animais - desnutrido sedentário

DT: grupo de animais - desnutrido treinado

EDL: músculo extensor digitório longo

ES: grupo de animais - eutrófico sedentário

ET: grupo de animais - eutrófico treinado

$\mathrm{H}^{+}$: íon hidrogênio

IMP: inosina monofosfato

LDH: lactato desidrogenase

NAD: nicotinamida adenina dinucleotídio (forma oxidada)

NADH: nicotinamida adenina dinucleotídio (forma reduzida)

PCR: reação da cadeia de polimerase 
PFK: fosfofrutocinase

RNA: ácido ribonucléico

RNAtot: RNA total

RPL19: proteína ribossomal 19

RT-PCR: transcrição reversa da reação da cadeia de polimerase

TAE: tecido adiposo epididimal

TAME: tecido adiposo mesentérico

TARP: tecido adiposo retroperitoneal

$\mathrm{VO}_{2 m a ́ x}:$ consumo máximo de oxigênio 


\section{LISTA DE FIGURAS}

Página

FIGURA 1 - Organograma representando a divisão dos grupos experimentais .31

FIGURA 2 - Acompanhamento da ingestão alimentar dos animais eutróficos (sedentários e treinados, ES e ET, respectivamente) durante 16 semanas. .38

FIGURA 3 - Progressão do peso corporal dos grupos eutrófico sedentário (ES), eutrófico treinado (ET), desnutrido sedentário (DS), desnutrido treinado (DT), avaliada durante 16 semanas. 39

FIGURA 4 - Peso corporal dos grupos eutrófico sedentário (ES), eutrófico treinado (ET), desnutrido sedentário (DS), desnutrido treinado (DT) na 16 a semana de tratamento .39

FIGURA 5 - Conteúdo total de gordura na carcaça (g)

FIGURA 6 - Conteúdo total de proteínas na carcaça (mg/ml).

FIGURA 7 - Gordura corporal percentual dos grupos eutrófico sedentário (ES), eutrófico treinado (ET), desnutrido sedentário (DS), desnutrido treinado (DT). .44

FIGURA 8 - Massa magra percentual dos grupos eutrófico sedentário (ES), eutrófico treinado (ET), desnutrido sedentário (DS), desnutrido treinado (DT). .44

FIGURA 9 - Concentração de proteínas no soro dos grupos eutrófico sedentário (ES), eutrófico treinado (ET), desnutrido sedentário (DS), desnutrido treinado (DT) .45

FIGURA 10 - Glicemia (mg/dl) nos grupos eutrófico sedentário (ES), eutrófico treinado (ET), desnutrido sedentário (DS), desnutrido treinado (DT).

FIGURA 11 - Insulinemia $(\mu \mathrm{UI} / \mathrm{ml})$ nos grupos eutrófico sedentário (ES), eutrófico treinado (ET), desnutrido sedentário (DS), desnutrido treinado (DT) 46 
FIGURA 12 - Relação Insulina/glicose ( ([insulina].( $\mu U \mathrm{UI} / \mathrm{ml})$ / [glicemia].(mg/dl) ) nos grupos eutrófico sedentário (ES), eutrófico treinado (ET), desnutrido sedentário (DS), desnutrido treinado (DT)

FIGURA 13 - Concentração de glicogênio (mg/100mg de tecido) nos grupos eutrófico sedentário (ES), eutrófico treinado (ET), desnutrido sedentário (DS), desnutrido treinado (DT)

FIGURA 14 - Concentração de glicogênio (mg/100mg de tecido) na porção vermelha do músculo esquelético gastrocnêmio nos grupos eutrófico sedentário (ES), eutrófico treinado (ET), desnutrido sedentário (DS), desnutrido treinado (DT)

FIGURA 15 - Tempo de exaustão em minutos (min) dos grupos eutrófico sedentário (ES), eutrófico treinado (ET), desnutrido sedentário (DS), desnutrido treinado (DT).

FIGURA 16 - Velocidade de exaustão (m/min) dos grupos eutrófico sedentário (ES), eutrófico treinado (ET), desnutrido sedentário (DS), desnutrido treinado (DT).

FIGURA 17 - Medida do $\mathrm{VO}_{2 \text { máx }}(\mathrm{ml} / \mathrm{kg} / \mathrm{min})$ realizado antes do período de treinamento dos grupos eutrófico sedentário (ES), eutrófico treinado (ET), desnutrido sedentário (DS), desnutrido treinado (DT) .50

FIGURA 18 - Medida do $\mathrm{VO}_{2 \text { máx }}(\mathrm{ml} / \mathrm{kg} / \mathrm{min})$ realizado após o período de 10 semanas de treinamento dos grupos eutrófico sedentário (ES), eutrófico treinado (ET), desnutrido sedentário (DS), desnutrido treinado (DT). .51 


\section{LISTA DE TABELAS}

Página

TABELA 1 - Protocolo de treinamento em esteira ergométrica..........................................30

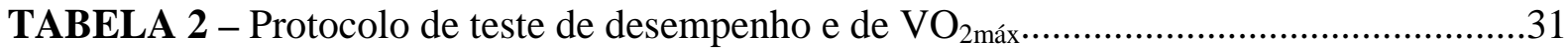

TABELA 3 - Seqüência dos primers do RT-PCR.................................................................36

TABELA 4 - Peso absoluto (g) dos músculos esqueléticos e do fígado................................40

TABELA 5 - Peso relativo (\%) dos músculos esqueléticos e do fígado...............................41

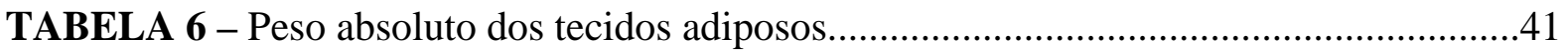

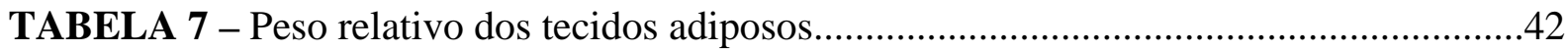

TABELA 8 - Conteúdo de gordura e proteínas na carcaça....................................................42

TABELA 9 - Análise da expressão gênica de proteínas no músculo EDL..............................51

TABELA 10 - Análise da expressão gênica de proteínas no músculo sóleo............................52

TABELA 11 - Análise da expressão gênica de proteínas no músculo gastrocnêmio..............52 


\section{Sumário}

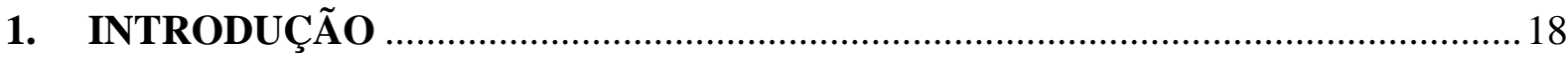

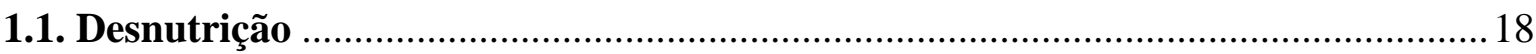

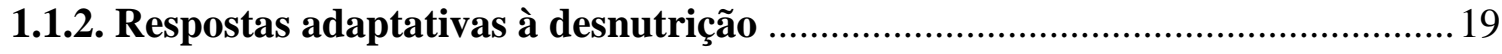

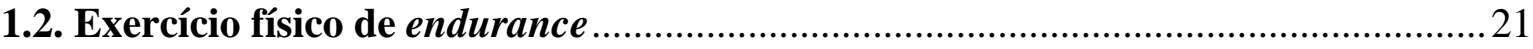

1.2.1. Exercício físico de endurance e seu efeito sobre o músculo esquelético ...........23

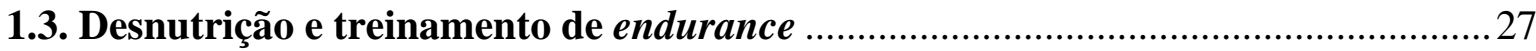

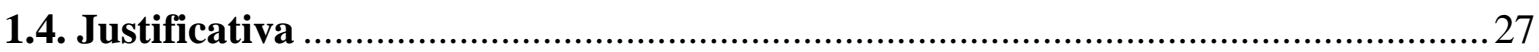

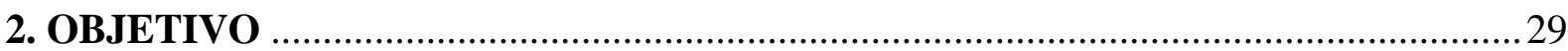

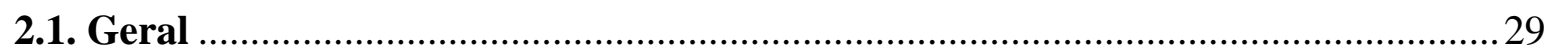

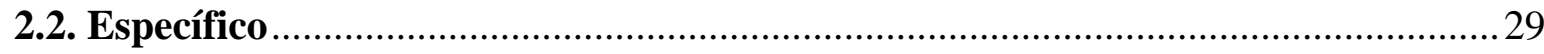

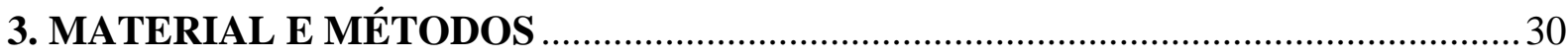

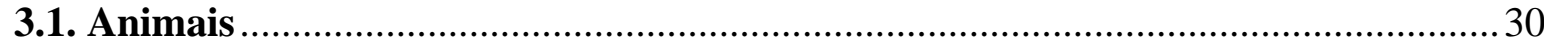

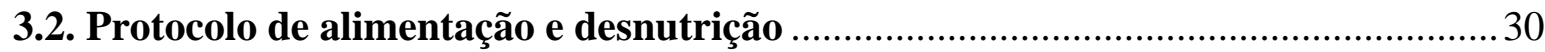

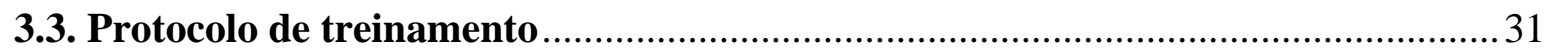

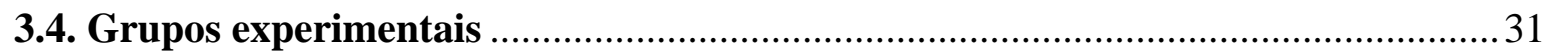

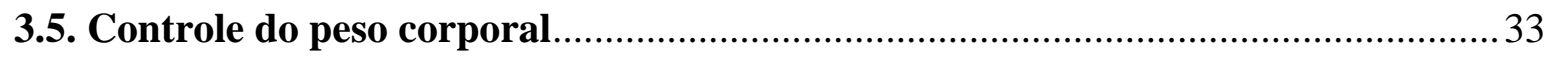

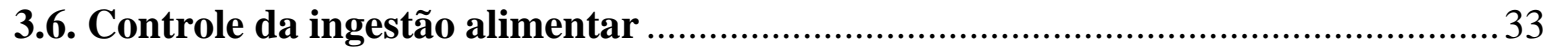

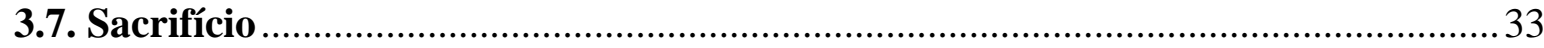

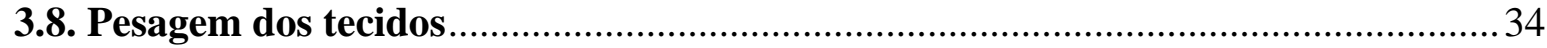

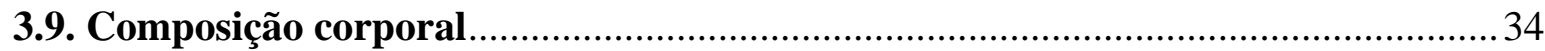

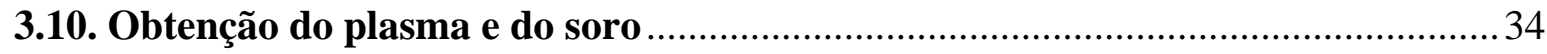

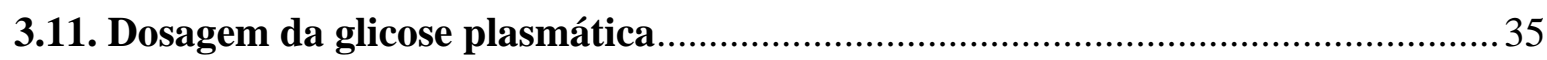

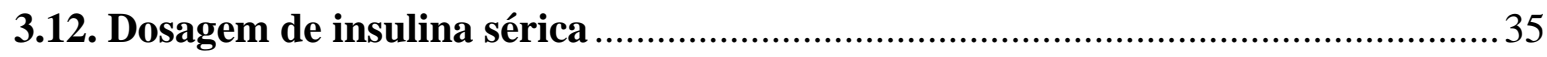

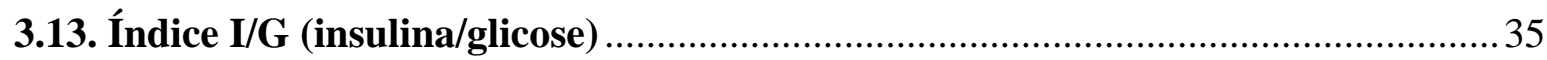

3.14. Determinação da concentração de proteína no soro ............................................. 35

3.15. Quantificação da concentração de glicogênio no músculo esquelético ................. 36

3.16. Análise da expressão gênica da PFK, LDH, CS, CPT I e CPT II .......................... 36

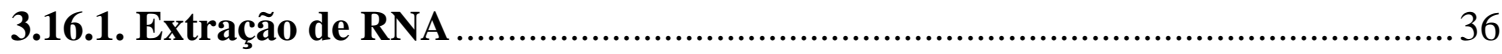

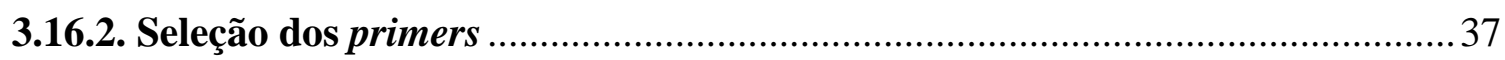

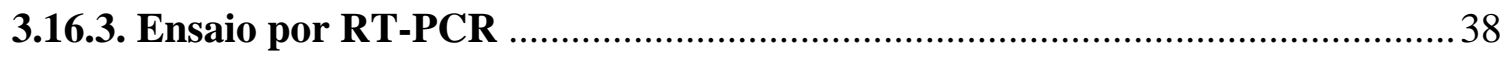

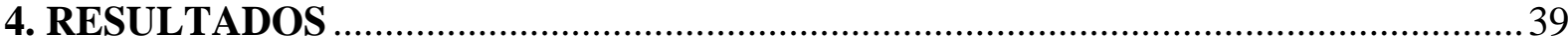

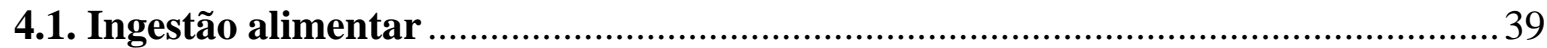




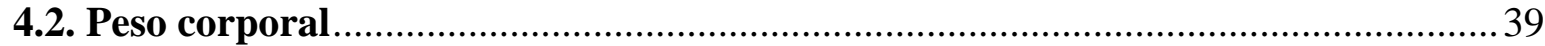

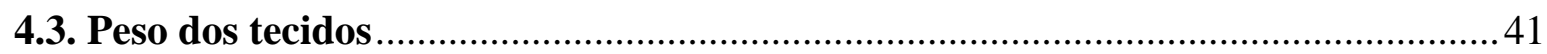

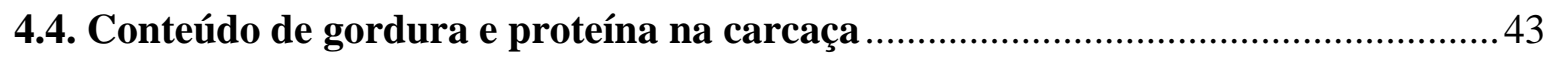

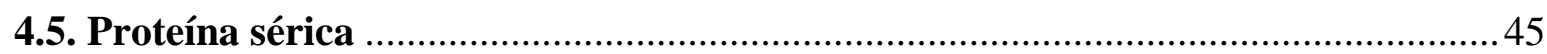

4.6. Concentração sangüínea de glicose e insulina....................................................... 46

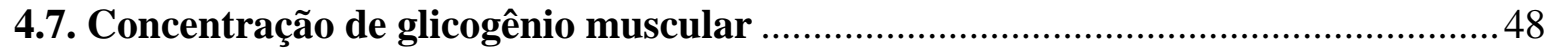

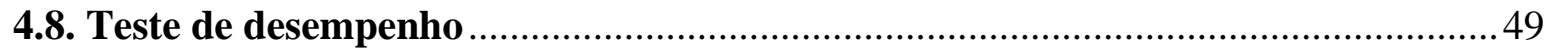

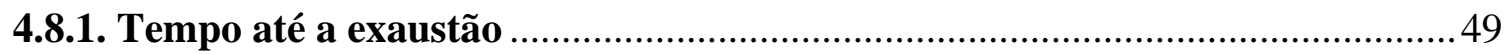

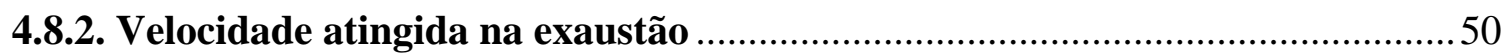

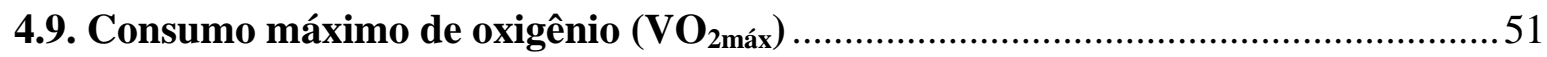

4.10. Análise da expressão gênica de proteínas musculares por RT-PCR …...............52

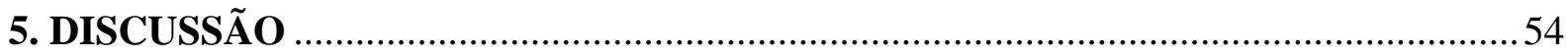

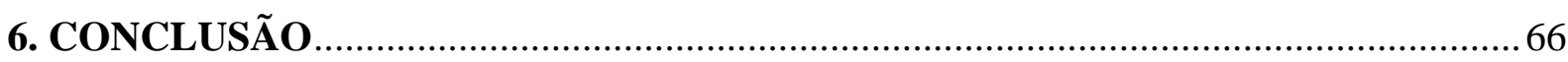

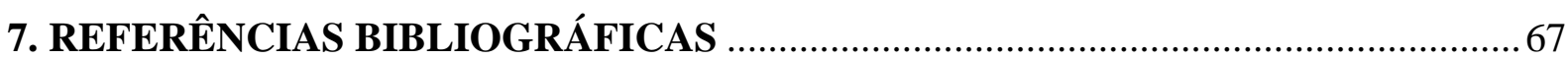




\section{INTRODUÇÃO}

\subsection{Desnutrição}

A desnutrição protéico-calórica ocorre quando as necessidades orgânicas para proteínas e/ou energia não são satisfeitas pela dieta, ou seja, está relacionada com a disponibilidade total de nutrientes. Diversas manifestações clínicas podem ocorrer e são condicionadas pela intensidade e/ou duração do déficit de proteína ou de energia, pela idade do hospedeiro, pela causa da deficiência e também pela associação com outras doenças nutricionais e infecciosas (TORUN \& CHEW, 1999).

A desnutrição protéico-calórica é um dos principais problemas de saúde pública em regiões tropicais e subtropicais no mundo, por estar relacionada a fatores ambientais, sociais, econômicos, e mesmo, biológicos (GINER et al, 1996; AKUYAM, 2007). É a mais comum desordem nutricional que afeta as crianças de países pobres e em desenvolvimento e o terceiro problema de saúde mais comum durante a infância nesses países (WHO, 2007). No Brasil, a desnutrição acomete cerca de 10,5\% da população, com uma taxa de mortalidade entre 20 e $30 \%$, segundo o IBGE (2000), sendo um problema de grande proporção a ser enfrentado pelas autoridades políticas e sociais, pois com a continuidade da desnutrição após a infância, um adulto jovem apresenta uma capacidade reduzida de trabalho impactando sua produtividade econômica. Além disso, esse quadro também está presente em pessoas da terceira idade, resultando em um aumento das hospitalizações e dos gastos públicos com a saúde, afetando o desenvolvimento da economia do país (SHOFIELD \& ASHWORTH, 1996).

Mais de 10 milhões de crianças morrem por ano devido à desnutrição em países pobres (BLACK et al, 2003), sendo que 42 países são responsáveis por 90\% das mortes em todo o mundo e, apenas seis desses são responsáveis por 50\% (UNICEF, 2007). Somente em 2001, 54\% da mortalidade infantil mundial pôde ser atribuída, direta ou indiretamente, à desnutrição (WHO, 2007). A principal causa de morte de desnutridos está associada a doenças infecciosas, sendo a pneumonia e a diarréia as mais freqüentes (KALTER et al, 1990). A desnutrição em si é capaz de desencadear doenças devido à supressão da função do sistema imunológico (CUNHA et al, 2003; KEUSCH, 2003). Parte dos efeitos da desnutrição, notadamente aqueles sobre a reposta imune, podem envolver alterações no equilíbrio do eixo neuroimunoendócrino. De fato, a desnutrição pode ser vista como um fator estressor, que, sabidamente pode levar à imunossupressão (LEONARD \& SONG, 1996), responsável, por exemplo, pela alta susceptibilidade de desnutridos à sepse bacteriana (HUANG, 2001). 
A origem da desnutrição pode ser primária, quando resulta de ingestão alimentar insuficiente, ou secundária, quando resulta de outras doenças que levam a uma baixa ingestão de alimento, absorção ou utilização inadequada de nutrientes, necessidades nutricionais aumentadas, ou ainda, perdas aumentadas de nutrientes (TORUN \& CHEW, 1999).

As deficiências dietéticas energético-protéica geralmente ocorrem juntas, mas em determinados casos há a predominância de uma deficiência sobre a outra, levando a síndromes conhecidas como marasmo ou kwashiorkor. O marasmo, deficiência predominante de energia, é resultado de uma adaptação à baixa ingestão alimentar, geralmente, levando à interrupção do crescimento e severa perda de massa muscular e tecido adiposo, enquanto o kwashiorkor, deficiência predominante de proteína, leva, em geral, ao acúmulo de gordura no fígado e ao edema generalizado (GOLDEN, 2002).

\subsubsection{Respostas adaptativas à desnutrição}

A desnutrição energético-protéica desenvolve-se gradualmente ao longo de semanas ou meses e isso permite diversos ajustes fisiológicos, metabólicos e comportamentais que resultam em uma diminuição da necessidade por nutrientes e um equilíbrio nutricional compatível com essa menor disponibilidade de nutrientes (TORUN \& CHEW, 1999), isto é, uma diminuição da ingestão alimentar é seguida por uma queda no gasto energético.

Quando a diminuição no gasto energético não é suficiente para compensar a diminuição da ingestão energética, a gordura corporal passa a ser mobilizada diminuindo a adiposidade e o peso corporal (BARAC-NIETO et al, 1978). Já a massa corporal magra diminui a uma taxa mais lenta, principalmente como conseqüência do catabolismo da proteína muscular para o fornecimento de energia (SHETTY, 1984). À medida que o déficit cumulativo de energia torna-se mais grave, a gordura subcutânea é reduzida acentuadamente e o catabolismo protéico leva à atrofia muscular (SOARES \& SHETTY, 1991). Nesse mesmo sentido, KATZEFF e colaboradores (1995) demonstraram que com apenas 28 dias de uma restrição calórica de $50 \%$ da ingestão alimentar, já se observa redução do peso dos músculos esqueléticos em relação à massa corporal total.

Além da modulação do gasto energético que leva a uma alteração da composição corporal, a desnutrição também provoca diversas alterações, como diminuição da velocidade de crescimento e de desenvolvimento (BARAC-NIETO et al, 1978; SPURR et al, 1983), alterações nos sistemas nervoso (TORUN \& CHEW, 1999), endócrino (OWENS et al, 1993) 
e imunológico (CHANDRA, 1983), assim como aumento do apetite (WOODS et al, 1998), alteração da função da hipófise (WADE et al, 1996), redução da atividade simpática em diversas regiões, incluindo o coração e o tecido adiposo marrom (YOUNG \& LANDSBERG, 1977; RAPPAPORT et al, 1982), aumento da atividade simpática no tecido adiposo branco (MIGLIORINI et al, 1997), atividade cardíaca vagal aumentada (ARONME et al, 1995; HALL et al, 1993), diminuição da freqüência cardíaca e da pressão arterial (YOUNG et al, 1978; ERNSBERGER \& NELSON, 1988), bem como adaptações metabólicas (RUSSELL et al, 1984a; DUMAS et al, 2004), como redução da taxa metabólica basal (SARIS, 1995) e redução da temperatura corporal (LANE et al, 2003; RIKKE et al, 2003), e também, adaptações das fibras musculares esqueléticas (HENRIKSSON, 1990; MAXWELL et al, 1992).

Já é sabido que a desnutrição também promove algumas adaptações metabólicas, embora nem todas sejam conhecidas, principalmente, quando associada ao exercício. Alguns estudos demonstraram, por exemplo, que a desnutrição promove uma diminuição da expressão de fosfofrutoquinase (PFK) e da succinato desidrogenase (SDH), enzimas da via glicolítica e do ciclo de Krebs, respectivamente (LAYMAN, et al, 1981; RUSSEL et al, 1984a; BISSONNETTE et al, 1997). Além disso, a desnutrição também gera uma diminuição da atividade de enzimas da cadeia respiratória (citocromo $c$ oxidase) no músculo esquelético, além de uma redução da geração de NADH pelo ciclo de Krebs, sugerindo uma diminuição da fosforilação oxidativa e uma alteração do consumo de oxigênio na mitocôndria (FUGE et al, 1968; LAYMAN, et al, 1981; MATECKI et al, 2002).

A quantidade de glicogênio parece ficar inalterada com a desnutrição (RUSSEL et al, 1984a), mas a de lactato e de piruvato apresentam uma elevação (RUSSEL et al, 1984b), sendo que uma hipótese para esses resultados é que há um aumento da glicólise e, para uma manutenção do glicogênio, um aumento da neoglicogênese. Do mesmo modo, ocorre uma diminuição dos estoques de ATP e um aumento do ADP livre (PICHARD et al, 1988), e diminuição da creatina fosfato (RUSSEL et al, 1984b). Uma concentração menor de mioglobina também é observada na desnutrição (FUGE et al, 1968).

Quanto à degradação protéica muscular há muitas controvérsias, existindo estudos relatando uma diminuição (GARLICK et al, 1975; RUSSEL et al, 1984a) e estudos descrevendo o seu aumento (LI \& WASSNER, 1984; LOWELL et al, 1986). HENRIKSSON (1990) afirma ainda que, a degradação protéica muscular aumenta com a desnutrição, porém diminui com a continuidade da mesma. 
Se a afirmação de que há um aumento da degradação protéica for a correta, parece que esta possui relação com a modificação do perfil dos tipos de fibras musculares, como demonstrado no estudo de RUSSEL et al (1984b), pois a desnutrição pode provocar uma diminuição do número das fibras musculares do tipo II, assim como uma diminuição do seu diâmetro e, um aumento da relação entre as fibras do tipo I/II.

Enfim, a desnutrição parece levar a diversas modificações no metabolismo energético, que podem alterar a resposta do indivíduo à demanda metabólica decorrente do exercício. Sabe-se, que a desnutrição resulta em uma diminuição da atividade de enzimas responsáveis pelo metabolismo glicolítico e oxidativo de carboidrato, promove uma diminuição da massa muscular e da força do músculo esquelético em ratos, porém, pouco se sabe ainda, como estas alterações se comportam frente ao exercício físico.

\subsection{Exercício físico de endurance}

O exercício físico de endurance é caracterizado por ser realizado de forma contínua e por um período prolongado de tempo (NOAKES, 2006), que varia desde 30 minutos a diversas horas de duração ininterruptas (ASTRAND, 2000). Quando realizado de forma regular, induz diversas adaptações em diferentes sistemas fisiológicos como, por exemplo, o endócrino, cardiovascular e muscular (COGGAN \& WILLIAMS, 1995) que, por sua vez, são determinantes da performance nesse exercício. As respostas desses sistemas variam, basicamente, de acordo com a intensidade, duração e o tipo de exercício de endurance realizado.

Como apresentado a seguir, as respostas do sistema endócrino já estão bem descritas na literatura. YOON \& PARK (1991) demonstraram uma clara relação dose-resposta entre a intensidade do exercício e a concentração plasmática de cortisol, hormônio adrenocorticotrófico (ACTH) e de $\beta$-endorfina. Nesse mesmo sentido, KUOPPASALMI e colaboradores (1980) demonstraram que a testosterona e o hormônio luteinizante não se alteraram após uma corrida de curta duração, mas ambos tiveram sua concentração reduzida após uma corrida de intensidade moderada por 90 minutos. Os hormônios também apresentam diferentes respostas frente à duração do exercício, como é o caso da testosterona que apresenta um aumento inicial durante o exercício de duração relativamente curta, mas quando 
o exercício é prolongado por mais de 2 horas, resulta em uma diminuição de sua concentração (CUMMING et al, 1989; KUOPPASALMI et al, 1980). O hormônio do crescimento aumenta rapidamente durante exercícios de curta duração, e apresenta uma estabilização após 30 minutos de exercício (RICHTER \& SUTTON, 1994). O cortisol e o glucagon não aumentam significativamente durante exercícios submáximos até cerca de 60 minutos (WARREN \& CONSTANTINI, 2000). A noradrenalina, em contraste, apresenta aumento significativo logo com poucos minutos do início do exercício (RICHTER \& SUTTON, 1994). Além disso, o tipo de exercício físico realizado também pode causar diferentes respostas hormonais. Um exemplo bem claro são as diferenças observadas com relação à concentração de testosterona que, como KUOPPASALMI e colaboradores (1976) e CUMMING e colaboradores descreveram, aumenta tanto no ciclismo quanto na corrida, porém, como observado por CUMMING e colaboradores (1987), diminui na natação. Segundo KRAEMER (1988), isso se explica por esses apresentarem um envolvimento de uma massa muscular diferente e, portanto, uma distinta resposta hormonal.

O exercício de endurance é também dependente do sistema cardiovascular, já que nutrientes e oxigênio precisam ser mobilizados e transportados para os diferentes tecidos ativos (SHEPHARD, 2000). Durante o exercício, os músculos ativos requerem um aumento da oferta de oxigênio em até 20 vezes em relação ao repouso e, para que o oxigênio chegue até a musculatura ativa, é necessário um aumento do fluxo sangüíneo durante o exercício, que aumenta em função da elevação do débito cardíaco e/ou da redistribuição do fluxo sangüíneo em direção aos músculos ativos (DENADAI, 1995). Essa oferta de oxigênio é determinante para o consumo máximo de oxigênio $\left(\mathrm{VO}_{2 m a ́ x}\right)$ que, por sua vez, é de extrema importância para o desempenho em exercícios de endurance, que depende, principalmente, do metabolismo oxidativo, sendo, portanto, um índice muito utilizado para classificar a capacidade funcional cardiorrespiratória (BASSET \& HOWLEY, 2000).

Assim, a adaptação do metabolismo do músculo esquelético ocorre em função de diversas alterações, sendo que, os sistemas endócrinol e cardiorrespiratório são de grande importância, já que a mobilização e o transporte de nutrientes e oxigênio, fundamental para o exercício de endurance, dependem dos mesmos. 


\subsubsection{Exercício físico de endurance e seu efeito sobre o músculo esquelético}

Como descrito anteriormente, o exercício físico de endurance depende, predominantemente, do metabolismo oxidativo das células musculares esqueléticas para a manutenção das contrações necessárias para a continuidade do mesmo, que requer a utilização de uma determinada taxa de energia, através da hidrólise da ATP e que, conseqüentemente, necessita ser ressintetizada (RUSH et al, 2000). Se a taxa de utilização de energia exceder a oferta pelo metabolismo oxidativo, o exercício não poderá ser sustentado e, rapidamente se desenvolverá a fadiga, que resultará em depleção dos estoques de energia, se ocorrer a tentativa de manter a intensidade do exercício, ou, uma diminuição da produção de força até atingir-se um nível em que o metabolismo oxidativo seja capaz de suprir a demanda energética (TERJUNG et al, 1985; WHITLOCK \& TERJUNG, 1987).

Quando o exercício físico de endurance é realizado de forma regular é caracterizado, então, o treinamento de endurance que induz respostas adaptativas estruturais e metabólicas no músculo esquelético. As fibras de contração lenta (fibras do tipo I), responsáveis por uma maior capacidade oxidativa, são as principais responsáveis pela realização desse tipo de exercício, mas com o treinamento de endurance, as fibras de contração rápida (fibras do tipo II) também assumem um perfil metabólico semelhante (HAMBRECHT et al, 1997; SUTER et al, 1995). Além disso, ocorre um aumento do número de capilares que perfundem o músculo esquelético, aumentando assim, a razão capilar/fibra muscular e, disponibilizando, dessa forma, um maior volume sanguíneo capaz de otimizar o transporte de gases e nutrientes e, dos subprodutos produzidos por esse tecido (ASTRAND, 2000).

Indivíduos treinados em endurance apresentam também uma alta capacidade oxidativa determinada por uma alta densidade mitocondrial (HAMBRECHT et al, 1997; MAUGHAN et al, 2000). Isso porque, o treinamento de endurance promove a biogênese de mitocôndrias por um processo bem complexo por elas serem compostas por proteínas codificadas tanto pelo DNA nuclear quanto mitocondrial (mtDNA) (HOOD \& SALEEM, 2007). O mesmo autor descreve resumidamente que o processo é iniciado pelo estímulo de cada sessão de treinamento que, através do aumento do fluxo de cálcio, das espécies reativas de oxigênio e também de AMPK (5'-AMP activated protein kinase) no músculo esquelético, promovem uma sinalização nuclear que levam à transcrição de genes que é mediada por um co-ativador, o PGC-1 $\alpha$ (PPAR- $\gamma$ co-ativador 1- $\alpha$ ). Segue-se, então, o controle da expressão gênica pelo fator de transcrição mitocondrial A (Tfam), importação de produtos derivados do núcleo para 
dentro da mitocôndria por sua maquinaria de importação e, a montagem de subunidades mitocondriais e nucleares em complexos funcionais enzimáticos.

Outros fatores determinantes do exercício de endurance são as adaptações metabólicas, que influenciam de forma direta os substratos energéticos a serem utilizados durante a realização do mesmo.

O glicogênio muscular e a glicose sangüíena, por exemplo, são substratos importantes para a ressíntese de ATP para a contração muscular durante o exercício (COYLE et al, 1986). A disponibilidade desses substratos durante o exercício prolongado é demonstrado pela fadiga que sempre se manifesta quando se observa a depleção tecidual do glicogênio e/ou a hipoglicemia (COGGAN \& COYLE, 1987; CONSTABLE et al, 1986; COYLE et al, 1983; COSTILL et al, 1971). Essa redução da disponibilidade de carboidrato resulta em redução dos níveis de piruvato (SAHLIN et al, 1990), que serve como substrato para a formação de acetilCoA e para reações que suprem os intermediários do ciclo de Krebs que, por sua vez, são necessários para a continuidade da oxidação de ácidos graxos e de amino ácidos (BERGER et al, 1976). Outro fator que sustenta a importância do glicogênio e da glicose sangüínea é que a suplementação com carboidratos durante o exercício de endurance é capaz de manter os níveis intramusculares dos intermediários do ciclo de Krebs e evitar a chegada da fadiga prolongando o exercício (COYLE et al, 1983; SLENTZ et al, 1990; SPENCER et al, 1991; SPENCER et al, 1992). Além disso, pacientes com a síndrome de McArdle, que apresentam deficiência da glicogênio fosforilase, enzima chave para a glicogenólise, não são capazes de utilizar o glicogênio muscular e apresentam uma capacidade de realizar exercício cerca de 50\% menor do que o esperado para indivíduos normais (LEWIS \& HALLER, 1986). Essas observações em conjunto, indicam que o glicogênio muscular e a glicose sangüínea são substratos essenciais para a ressíntese de ATP e, portanto, para a realização de exercícios prolongados.

A utilização do glicogênio muscular durante o exercício ocorre como resultado da ativação da glicogênio fosforilase e da fosfofrutocinase (PFK), enzimas-chave para glicogenólise e glicólise, respectivamente. Juntamente com a hexocinase (HK), que cataliza a fosforilação da glicose captada da circulação sangüínea, a glicogênio fosforilase é responsável por fornecer unidades de glicose para a via glicolítica. $O$ passo seguinte da hexosemonofosfato e da formação de triosefosfato é determinado pela atividade da PFK, que é sensível a diversos intermediários metabólicos (STANLEY \& CONNETT, 1991), que incluem os substratos frutose 6-fosfato (F-6-P); hexose bisfosfato (glicose 1,6-bisfosfato, G1,6- 2 $_{2}$; a ATP, ADP e AMP; íons hidrogênio; e o citrato (STANLEY \& CONNETT, 1991). 
O maior regulador da atividade da PFK é o estado energético da célula muscular, com a quantidade de substrato que lhe é fornecida (STANLEY \& CONNETT, 1991).

Durante a realização do exercício prolongado, ocorre uma diminuição da concentração de hexosefosfato e uma maior concentração de inosina monofosfato (IMP), porém, a concentração de piruvato e lactato muscular também diminuem, resultando em uma redução da glicólise (SPENCER et al, 1992). Essas alterações metabólicas foram associadas com uma menor concentração de intermediários do ciclo de Krebs, como o citrato, malato e fumarato (SPENCER et al, 1992). Isso enfatiza o importante papel da glicólise no metabolismo energético no músculo esquelético durante o exercício, pois não apenas serve como uma fonte complementar de ATP quando a produção oxidativa não é mais capaz de suprir a demanda, mas também possui um papel vital na geração de substratos para as reações que irão fornecer intermediários do ciclo de Krebs (STANLEY \& CONNETT, 1991). A hexose bisfosfato é um potente ativador da PFK, mas não há evidências de que essa seja um importante regulador do metabolismo de carboidrato no músculo esquelético durante o exercício (KATZ et al, 1988). Embora aumentos na concentração de $\mathrm{H}^{+}$inibam a atividade da PFK in vitro, parece que alterações em outros moduladores da PFK são suficientes para assegurar sua adequada atividade durante o exercício, mesmo com um grande aumento de $\mathrm{H}^{+}$intramuscular (SPRIET, 1991).

Mais adiante, no final do processo da glicólise ou da glicogenólise, ocorre a formação de piruvato que pode ser metabolizado no citoplasma para se transformar em acetil-CoA, ou ainda, ser convertido em lactato com a oxidação de NADH em NAD em uma reação catalizada pela lactato desidrogenase (LDH) (HARGRAVES, 1995). Por muitos anos o lactato foi considerado apenas um subproduto metabólico, mas, posteriormente, evidências demonstraram que o lactato é um importante intermediário metabólico, servindo tanto como um precursor para a gliconeogênese no fígado (WASSERMAN et al, 1991) quanto como um substrato oxidativo para a contração muscular esquelética e cardíaca (STANLEY et al, 1986; GERTZ et al, 1988). Como a LDH é uma enzima de equilíbrio, o aumento na produção de lactato ocorre por um efeito de ação em massa exercido pelo aumento nas concentrações de piruvato (STALLKNECHT et al, 1998). Para manter um equilíbrio, a LDH favorece a reação de piruvato a lactato, já que pequenos aumentos na concentração de piruvato resultam em aumentos consideráveis na concentração de lactato (HEIGENHAUSER \& PAROLIN, 1999).

Como alternativa da conversão do piruvato em lactato, o primeiro pode, por meio do metabolismo oxidativo, ser transformado em dióxido de carbono $\left(\mathrm{CO}_{2}\right)$ e água. O piruvato é, então, transportado através da membrana mitocondrial por uma proteína transportadora 
específica, e esse processo ocorre no interior da mitocôndria (HEIGENHAUSER \& PAROLIN, 1999). O primeiro passo é a conversão do piruvato em um grupo acetato que é unido à coenzima-A para formar a acetil-CoA. Essa última se combina, então, com o oxaloacetato para formar citrato, reação que ocorre no ciclo de Krebs (SPRIET \& HEIGENHAUSER, 2002), catalizada pela enzima citrato sintase (CS). É válido ressaltar que um ponto chave da regulação do ciclo de Krebs é essa reação catalisada pela CS e que, por sua vez, pode ter sua atividade afetada pela disponibilidade de citrato, ou ainda, ser inibida por acil-CoA derivados de ácidos graxos (SPRIET \& HOWLET, 1999).

Os ácidos graxos são importantes substratos para a produção de ATP durante a realização de exercícios de endurance. Um aumento da oxidação de ácidos graxos é facilitado pelo aumento da capacidade de captá-los para a célula muscular (IBRAHIMI et al, 1999) e transportá-los para a mitocôndria para serem oxidados (HELGE \& KIENS, 1997) num processo chamado $\beta$-oxidação. A oxidação de ácidos graxos na mitocôndria é essencial para a manutenção da homeostase energética em situações que requerem, simultaneamente, poupar glicose e fornecer maior suprimento de energia (BONNEFONT et al, 2004), como é o caso do exercício de endurance. Mas, os ácidos graxos de cadeia longa, a maior fração de ácidos graxos fornecidos aos tecidos-alvo, não podem atingir a matriz mitocondrial por difusão simples (BARLETT \& EATON, 2004). Assim, um importante passo na $\beta$-oxidação de ácidos graxos de cadeia longa é o transporte através das membranas mitocondriais (McGARRY \& BROWN, 1997; McGARRY et al, 1983; McGARRY et al, 1978). Esse transporte é dependente de L-carnitina e é catalizado por um complexo enzimático denominado carnitina palmitoiltransferase (CPT), que consiste das CPT I, CPT II e CAT. A CPT I está localizada na membrana externa da mitocôndria e cataliza a transferência de grupos acil-CoA para a carnitina formando a acilcarnitina e CoA livre. A proteína acilcarnitina carnitina translocase (CACT), localizada na membrana interna da mitocôndria, troca as acilcarnitinas do citoplasma por carnitina livre da mitocôndria. Por fim, a enzima CPT II, localizada na membrana mitocondrial interna, cataliza a reação que é reversa àquela da CPT I, reconvertendo acilcarnitina a acil-CoA, que é encaminhada para a $\beta$-oxidação, enquanto carnitina livre é produzida (BERTHON et al, 1998).

Assim, fica evidente que a regulação do metabolismo energético para a produção de energia no músculo esquelético com o treinamento de endurance parece ser de fundamental importância para que um bom desempenho seja obtido. 


\subsection{Desnutrição e treinamento de endurance}

Poucos são os estudos que buscaram avaliar os efeitos do exercício sobre aqueles decorrentes da desnutrição. O que se encontra na literatura são estudos em que desnutridos são submetidos, apenas, a um teste de exercício agudo para verificar sua resposta frente a esse quadro de estresse, como os publicados por BARAC-NIETO et al (1978 e 1980) e por SPURR et al (1983 e 1984), que demonstraram haver uma redução do consumo máximo de oxigênio em indivíduos desnutridos em relação a normais. Porém, esses estudos avaliaram esses parâmetros em desnutridos sem que passassem, previamente, por um período de treinamento.

Apesar disso, seguindo em outra linha parecida, o paradoxo do corredor africano fornece indícios de que as alterações na composição corporal causadas pela desnutrição na infância e adolescência podem estar relacionadas com o melhor desempenho de endurance apresentado por esses indivíduos quando submetidos ao treinamento de endurance na idade adulta, mesmo que, esses não sejam mais considerados desnutridos (WESTON et al, 1999).

Uma das hipóteses levantadas é de que a melhor performance do corredor africano em corridas de longa distância esteja relacionada ao seu baixo peso e adiposidade corporal, além de sua pequena massa muscular (CONLEY \& KRAHENBUHL, 1980; COETZER et al, 1993).

Pensando, então, paralelamente ao paradoxo do corredor africano, surgiu a indagação de quais seriam as respostas metabólicas e de performance em desnutridos submetidos ao treinamento de endurance.

\subsection{Justificativa}

A desnutrição parece levar a diversas modificações no metabolismo energético, que podem alterar a resposta do indivíduo à demanda metabólica decorrente do exercício. Sabe-se, que a desnutrição resulta em uma diminuição da atividade de enzimas responsáveis pelo metabolismo glicolítico e oxidativo de carboidrato, promove uma diminuição da massa muscular e da força do músculo esquelético em ratos. A respeito do treinamento de endurance, ao contrário, muito já se sabe com relação aos seus efeitos sobre o metabolismo energético em diversos tecidos, assim como sobre a composição corporal, e diversos outros fatores. Porém, pouco se sabe ainda, sobre a associação de duas situações estressoras, como a 
desnutrição e o exercício físico, que são capazes de promover outras respostas adaptativas ainda pouco estudadas. Tendo em vista, ainda, o paradoxo do corredor africano, que, mesmo com um histórico de desnutrição, é capaz de alcançar desempenhos melhores que atletas que recebem nutrição adequada, procurou-se averiguar o efeito combinado da desnutrição ao treinamento de endurance. 


\section{OBJETIVO}

\subsection{Geral}

Sabendo de algumas alterações que a desnutrição e, separadamente, o treinamento de endurance podem provocar, o objetivo desse estudo foi avaliar os efeitos combinados do treinamento físico de endurance e da desnutrição por um período prolongado de tempo.

\subsection{Específico}

Caracterizar os efeitos combinados dos protocolos de desnutrição, de 16 semanas, e de treinamento de endurance, de 10 semanas, sobre:

- A composição corporal, através da progressão do peso corporal, da adiposidade, e da massa muscular;

- Parâmetros metabólicos sangüíneos, como o conteúdo de glicose, insulina e proteínas;

- A concentração de glicogênio muscular;

- O consumo máximo de oxigênio;

- O desempenho de corrida, através do tempo e da velocidade atingida até a exaustão;

- A expressão gênica de algumas proteínas-chave do metabolismo no músculo esquelético como a PFK, LDH, CS, e a CPT I e CPT II. 


\section{MATERIAL E MÉTODOS}

\subsection{Animais}

Foram utilizados ratos machos, da linhagem Wistar (rattus norvegicus), obtidos no biotério central do Instituto de Ciências Biomédicas da Universidade de São Paulo - USP, a partir do desmame, com 21 dias de vida, com peso entre 100 e 120 g, e separados, aleatoriamente, em dois grupos, eutróficos e desnutridos. Foram mantidos em gaiolas individuais, em biotério com ciclo invertido de claro/escuro de 12/12horas, com início do período escuro às 7:00, no Biotério do Departamento de Biologia Celular e do Desenvolvimento do Instituo de Ciências Biomédicas I da USP. A temperatura ambiente e a umidade relativa do ar foram controladas a $23 \pm 2{ }^{\circ} \mathrm{C}$ e $60 \%$, respectivamente.

Os procedimentos experimentais estão de acordo com os Princípios Éticos em Experimentação Animal adotado pelo Colégio Brasileiro de Experimentação Animal (COBEA), com aprovação do protocolo para o uso de animais em experimentação (n ${ }^{0 .}$ 009, f. 13, livro 2, 2005) aprovado pela Comissão de Ética em Experimentação Animal (CEEA) em reunião realizada em 17/02/2005.

\subsection{Protocolo de alimentação e desnutrição}

Após o desmame, para o grupo dos eutróficos foi oferecida uma quantidade conhecida de ração “NUVILAB ${ }^{\circledR}$ CR1 (Nutrivital Nutrientes Ltda.)” disponibilizada ad libitum aos animais, sendo quantificado o total ingerido diariamente. A partir deste valor, ofereceu-se diariamente para o grupo de animais desnutridos, o correspondente a $50 \%$ do valor da ingestão diária dos eutróficos. A oferta de alimento ocorreu em horários alternados para evitar alterações fisiológicas decorrentes do efeito cronador que a alimentação poderia desencadear. A água foi oferecida ad libitum para ambos os grupos. A partir do $30^{\circ}$ dia, os grupos foram subdivididos, aleatoriamente, em grupos de animais sedentários e submetidos ao treinamento físico de endurance. A divisão dos grupos está descrita a seguir (grupos exeperimentais). 


\subsection{Protocolo de treinamento}

Os grupos de animais treinados foram submetidos ao exercício em esteira, durante 10 semanas, 5 vezes por semana. $\mathrm{Na} 1^{\mathrm{a}}$. semana de treinamento foi realizado um período de adaptação, iniciando-se com 30 minutos de exercício na $2^{\mathrm{a}}$. feira, aumentando 5 minutos por dia até 50 minutos na 6 . feira, a uma velocidade inicial de 5 metros por minuto $(\mathrm{m} / \mathrm{min})$. A velocidade da esteira foi gradativamente aumentada a cada semana até $23 \mathrm{~m} / \mathrm{min}$ nas duas últimas semanas de treinamento (DOS SANTOS CUNHA et al, 2004), conforme descrito na tabela 1.

Tabela 1. Protocolo de treinamento em esteira ergométrica.

\begin{tabular}{lcccccccc}
\hline & 2a. feira & 3a. feira & 4a. feira & 5a. feira & 6a. feira & & \\
\hline & $\begin{array}{c}\text { Tempo } \\
(\mathrm{min})\end{array}$ & $\begin{array}{c}\text { Tempo } \\
(\mathrm{min})\end{array}$ & $\begin{array}{c}\text { Tempo } \\
(\mathrm{min})\end{array}$ & $\begin{array}{c}\text { Tempo } \\
(\mathrm{min})\end{array}$ & $\begin{array}{c}\text { Tempo } \\
(\mathrm{min})\end{array}$ & $\begin{array}{c}\text { Vel. } \\
(\mathrm{m} / \mathrm{min})\end{array}$ & Teste \\
\hline 1a. semana & 30 & 35 & 40 & 45 & 50 & 5 & Exaustão/VO2máx \\
2a. semana & 30 & 35 & 40 & 50 & 60 & 10 & \\
3a. Semana & 30 & 35 & 40 & 50 & 60 & 13 & \\
4a. semana & 30 & 35 & 40 & 50 & 60 & 15 & \\
5a. semana & 30 & 35 & 40 & 50 & 60 & 18 & \\
6a. semana & 30 & 35 & 40 & 50 & 60 & 20 & \\
7a. semana & 30 & 35 & 40 & 50 & 60 & 21 & \\
8a. semana & 30 & 35 & 40 & 50 & 60 & 22 & \\
9a. semana & 50 & 50 & 60 & 60 & 60 & 23 & \\
10a. semana & 50 & 50 & 60 & 60 & 60 & 23 & Exaustão/VO2máx \\
\hline
\end{tabular}

\subsection{Grupos experimentais}

1. Eutrófico Sedentário (ES): ratos alimentados ad libitum;

2. Eutrófico Treinado (ET): ratos alimentados ad libitum submetidos a 10 semanas de treinamento;

3. Desnutrido Sedentário (DS): ratos que ingeriram 50\% da ração que o eutrófico consumia; 
4. Desnutrido Treinado (DT): ratos que ingeriram 50\% da ração que o eutrófico consumia e submetidos a 10 semanas de treinamento.

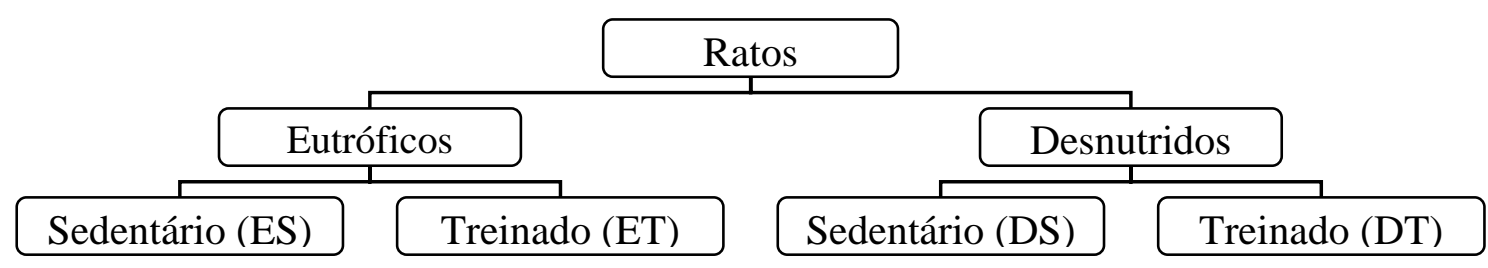

Figura 1. Organograma representando a divisão dos grupos experimentais.

\subsection{Teste de desempenho e de consumo máximo de oxigênio $\left(\mathrm{VO}_{2 m a ́ x}\right)$}

O teste que avaliou o desempenho e o $\mathrm{VO}_{2 \text { máx }}$ foi realizado no início e ao término do período de treinamento. No dia da realização do teste não houve treinamento. O protocolo do teste está descrito na tabela 2.

Tabela 2. Protocolo de teste de desempenho e de $\mathrm{VO}_{2 \text { máx}}$.

\begin{tabular}{cc}
\hline Tempo do Estágio (min) & Velocidade $(\mathrm{m} / \mathrm{min})$ \\
\hline 3 & 10 \\
3 & 15 \\
5 & 20 \\
5 & 25 \\
5 & 30 \\
5 & 35 \\
5 & 40 \\
5 & 45 \\
Sucessivamente até a exaustão
\end{tabular}

Com a realização deste teste obtivemos, então, os resultados de desempenho através do tempo decorrido até a exaustão e da velocidade atingida no momento da fadiga, assim como, ao término do teste, também obtivemos os resultados de $\mathrm{VO}_{2 \text { máx }}$.

As amostras de ar coletadas para avaliação do $\mathrm{VO}_{2 \text { máx }}$ foram coletadas em um sistema de calorimetria de circuito aberto Columbus Instrument, através do monitoramento da fração de oxigênio e gás carbônico na entrada e saída em uma câmara com fluxo de ar constante de $1 \mathrm{ml} / \mathrm{min}$. Após um período de 10-20min, para estabilização do aparelho, os ratos foram submetidos a 3 minutos de aquecimento a uma velocidade de $10 \mathrm{~m} / \mathrm{min}$ e mais 3 minutos a 
15m/min. A partir daí, cada estágio tinha duração de 5 minutos com incrementos de $5 \mathrm{~m} / \mathrm{min}$ até a exaustão do animal.

A exaustão foi determinada após os ratos permanecerem por 5 segundos no local de estimulação elétrica.

O aparelho utilizado foi o Oximax Columbus System (Columbus Instruments, Columbus, $\mathrm{OH})$.

\subsection{Controle do peso corporal}

Durante o período experimental, os animais foram pesados uma vez por semana, no mesmo dia da semana e no mesmo período, em balança manual (Ohaus, USA). O peso final dos animais corresponde àquele aferido horas antes do momento do sacrifício (16 ${ }^{\mathrm{a}}$. semana).

\subsection{Controle da ingestão alimentar}

Para o grupo de animais eutróficos, era oferecido $150 \mathrm{~g}$ de ração por semana. Uma vez por semana, sempre no mesmo dia, era retirado a ração restante e calculado o ingerido na semana. Dividia-se, então, por 7 (dias da semana) e era obtido o resultado da ingestão diária dos grupos eutróficos. A partir daí, era calculado 50\% e oferecido, diariamente, em horários aleatórios, aos animais dos grupos desnutridos. A ração era pesada em balança digital Adventurer ${ }^{\mathrm{TM}}$ Ohaus ${ }^{\circledR}$ (USA) com precisão de 4 casas decimais. O desvio padrão da ração oferecida aos desnutridos foi padronizado em $\pm 0,1 \mathrm{~g}$.

\subsection{Sacrifício}

Os animais foram sacrificados por decapitação com guilhotina, sem anestesia, um dia após a última sessão de treinamento e, sempre, com início no mesmo horário (8:00) para evitar a discrepância dos resultados decorrentes da variação circadiana e aqueles da última sessão de treinamento. Além disso, o sacrifício entre os animais de cada grupo foi realizado alternadamente, ou seja, primeiro um animal do grupo ES, depois do grupo ET, depois DS, e então, DT, e assim, seguia-se nessa seqüência até o final do sacrifício. 


\subsection{Pesagem dos tecidos}

Logo após o sacrifício, os tecidos musculares (sóleo, extensor digitório longo (EDL) e gastrocnêmio (gastro)), o fígado e os tecidos adiposos (retroperitoneal (TARP), epididimal (TAE) e mesentérico (TAME)) foram retirados do animal e pesados em balança digital Adventurer $^{\mathrm{TM}}$ Ohaus $^{\circledR}$ com precisão de quatro casas decimais. O peso foi expresso em valores absolutos (g) e relativos ao peso corporal $(\%=$ (peso do tecido/peso corporal)*100).

\subsection{Composição corporal}

Foi realizada uma pesagem semanal de cada rato para acompanhar a progressão de peso e confirmação do estado de desnutrição dos animais privados de alimento (CUNHA et al, 2003; DOS SANTOS CUNHA et al, 2004).

O conteúdo de lipídios foi medido a partir da carcaça utilizando-se o método adaptado de STANSBIE et al (1976).

O conteúdo de proteína foi medido a partir da carcaça utilizando o método adaptado de LOWRY et al (1951).

A avaliação do conteúdo de massa gorda relativo ao peso corporal foi realizado a partir do seguinte cálculo: \% gordura = $(\text { quantidade de gordura }(\mathrm{g}) / \text { peso carcaça }(\mathrm{g}))^{*} 100$.

O conteúdo de massa magra foi avaliado a partir do seguinte cálculo: \%massa magra = 100 - \%gordura.

\subsection{Obtenção do plasma e do soro}

Após o sacrifício dos animais o sangue total foi coletado e armazenado em tubos plásticos (tubos Falcon de 15ml) contendo $100 \mu \mathrm{l}$ de heparina, para a extração do plasma, ou seco, para obtenção do soro, que se deram após a centrifugação a 1500rpm durante 15 minutos à temperatura de $4^{\circ} \mathrm{C}$. Após o final da centrifugação, o plasma foi aliquotado em tubos do tipo eppendorf ( $2 \mathrm{ml})$ e armazenado em freezer $-80^{\circ} \mathrm{C}$ para posteriores dosagens. 


\subsection{Dosagem da glicose plasmática}

Foi determinada através de kit enzimático comercial Glicose HK Labtest ${ }^{\circledR}$ Diagnóstica que consiste no seguinte princípio: a ATP promove a fosforilação da glicose em uma reação catalisada pela hexoquinase (HK). A glicose-6-fosfato produzida na reação é oxidada a 6fosfogluconato na presença de NAD, em reação catalisada especificamente pela glicose-6fosfato desidrogenase (G-6-PDH). Ocorre a produção de um mol de NADH para cada mol de glicse-6-fosfato que é oxidado. A absorbância resultante, medida em 340nm, é diretamente proporcional à concentração da glicose na amostra.

\subsection{Dosagem de insulina sérica}

Foi determinada através do kit comercial da COAT-A-COUNT ${ }^{\circledR}$ Insulin por radioimunoensaio que consiste no princípio da competição entre a insulina porcina marcada com radioisótopo ${ }^{125}$ I e a insulina fria (não marcada) pelo anticorpo anti-insulina produzido no animal. Mantendo-se constante a quantidade de hormônio radioativo e do anticorpo, a formação do complexo insulina marcada-anticorpo depende da quantidade de insulina fria presente na solução padrão. A concentração do hormônio na amostra foi determinada pela quantificação de radiação gama (em contagem por minuto).

\subsection{3. Índice I/G (insulina/glicose)}

A determinação do índice I/G foi realizada através da razão entre as concentrações de insulina e glicose.

\subsection{Determinação da concentração de proteína no soro}

O conteúdo de proteínas séricas foi determinado pelo método descrito por LOWRY et al (1951), usando-se albumina bovina como padrão. O princípio consiste na hidrólise alcalina das proteínas celulares, com posterior reação de hidroxilas fenólicas com reagente colorimétrico de Folin, que pode ser acompanhada espectrofotometricamente a 750nm. 


\subsection{Quantificação da concentração de glicogênio no músculo esquelético}

A dosagem do glicogênio no músculo esquelético foi determinada a partir do método descrito por SJÖRGREEN et al (1938) e por HASSID \& ABRAHAMS (1957).

As amostras de 250mg do tecido muscular esquelético gastrocnêmio foram digeridas em tubos de vidro contendo $1 \mathrm{ml}$ de $\mathrm{KOH}(0,053 \mathrm{~mol} / \mathrm{l})$ em banho fervente por 40 a 60 minutos. Após este período foram acrescentados $100 \mu \mathrm{l}$ de $\mathrm{Na}_{2} \mathrm{SO}_{4}$ saturado e 3,5ml de etanol (1mol/l), mantido em banho fervente até o início da ebulição das amostras.

Em seguida, as amostras foram centrifugadas a 2000rpm durante 20 minutos. O sobrenadante foi removido, sendo adicionado $1 \mathrm{ml}$ de água quente para ressuspender o precipitado. As amostras foram agitadas no vórtex e acrescentado 3,5ml de etanol (1mol/l). Este processo foi repetido 2 vezes.

Para a leitura, foram utilizados tubos de vidro de $5 \mathrm{ml}$ contendo $50 \mu \mathrm{l}$ de amostra mais $950 \mu \mathrm{l}$ de água e $2 \mathrm{ml}$ de antrona. Para a leitura do branco, $1000 \mu \mathrm{l}$ de água mais $2 \mathrm{ml}$ de antrona. Para a cuva, $2 \mathrm{ml}$ de antrona mais $1000 \mu \mathrm{l}$ da solução padrão. As amostras permaneceram por 15 minutos em banho fervente antes da leitura.

As leituras das absorbâncias foram realizadas em espectrofotômetro com comprimento de onda de 650nm.

\subsection{Análise da expressão gênica da PFK, LDH, CS, CPT I e CPT II}

Para reduzir a presença de RNAses, foram adotados os seguintes cuidados em todos os procedimentos: utilização de material esterilizado e descartável; esterilização da vidraria (em forno a $250^{\circ} \mathrm{C}$ por 3 horas); manipulação de amostras e materiais com luvas; utilização de água com dietil-pirocarbonato (água Sigma-DEPC 0,01\% vol/vol em 3 vezes de 200ml, sob agitação magnética), por 12 horas e autoclavada (SAMBROOK et al, 1989).

\subsubsection{Extração de RNA}

Para isolar o RNA total do músculo esquelético sóleo, EDL e gastrocnêmio, as amostras pesando entre 0,2 e 0,6g foram homogeneizadas em Trizol ${ }^{\circledR}$ Reagent em aparelho Politron. As amostras foram precipitadas com $200 \mu$ l de clorofórmio e centrifugadas por 
15minutos a $12000 \cdot \mathrm{g}$ a $4^{\circ} \mathrm{C}$ para a obtenção do RNA total (fase superior). Este foi precipitado com $500 \mu \mathrm{l}$ de álcool isopropílico e incubado por 10 minutos à temperatura ambiente. Os pellets foram lavados com etanol $75 \%$ e as amostras centrifugadas por 5 minutos a $7500 \cdot \mathrm{g}$, a $4^{\circ} \mathrm{C}$. O álcool foi removido e os pellets secos à temperatura ambiente. As amostras foram solubilizadas em água - DEPC. Para avaliação da concentração e pureza do RNA total foram realizados ensaios espectrofotométricos sob comprimento de onda de 260nm (correspondente ao pico de absorção de RNA) e 280nm (correspondente ao pico de absorção de proteínas).

\subsubsection{Seleção dos primers}

Os primers foram sintetizados pela Integrated DNA Technologies (Prodimol Biotecnologia S/A). A seqüência foi determinada usando o software Primer 3, disponível online no site http://www.genome.wi.mit.edu, selecionados sempre de acordo com os seguintes parâmetros: comprimento entre 18 e 24 pares de base (bp), com comprimento ótimo de 20-22 bases, $\mathrm{T}_{\mathrm{m}}$ entre 58 e $62^{\circ} \mathrm{C}$, com temperatura ótima de $60^{\circ} \mathrm{C}$ e comprimento do produto amplificado entre 100 e 150 bp. O conteúdo de C + G foi entre 40 e 60\%, com conteúdo ótimo acima de 50\%, e neste caso, seqüências e bases repetidas ( $>3$ bases idênticas) foram evitadas. Para determinar a especificidade, todas as seqüências foram comparadas com o Genebank usando o programa Blast disponível no site da National Center for Biotechnology Information (www.ncbi.nlm.gov). Quando ambas as seqüências dos primers demonstraram homologia para o mesmo gene, diferente daquele de interesse, essas foram descartadas. Todos os primers selecionados para o PCR foram configurados de maneira que o produto amplificado fosse sintetizado em exons diferentes, evitando desta forma, a contaminação do DNA genômico.

Tabela 3. Seqüência dos primers do RT-PCR.

\begin{tabular}{cccc}
\hline Gene & Primer sense & Primer antisense & Genebank \\
\hline PFK & ATGGGTGTGGAAGCAGTG & GTGTGCAACCCGCCCTTAGA & NM031715 (Pubmed) \\
LDH & GGAAGTGGTTGCAATCTGGA & ATCCTTCCACTGCTCCTTGT & NM017025 (Pubmed) \\
CS & GGGCTTATTTTGGCTGCTGG & CCGGGCGAAGTTGCTTTC & NM130755 (Pubmed) \\
CPT I & & & \\
CPT II & & & \\
\hline
\end{tabular}




\subsubsection{Ensaio por RT-PCR}

\subsubsection{Geração de cDNA por transcrição reversa}

O DNA complementar (cDNA) foi gerado pela incubação de $3 \mu$ g de RNAtot na presença de $2 \mu \mathrm{l}$ de OligoDTs $(0,05 \mu \mathrm{g} / \mu \mathrm{l})$ e $2 \mu \mathrm{l}$ de M-MLV Reverse Transcriptase Gibco (20U), completando com água-DEPC para $20 \mu \mathrm{l}$ de volume total de reação, por 10 minutos a $21^{\circ} \mathrm{C}, 30$ minutos a $42^{\circ} \mathrm{C}$ e 10 minutos a $99^{\circ} \mathrm{C}$ em termociclador.

O cDNA foi fracionado em gel de agarose $1 \%$ sob voltagem de $85 \mathrm{~V}$ e corado com brometo de etídio para visualização de imagem no transiluminador. Um marcador para número de pares de base foi aplicado ao mesmo gel (DNA ladder, Gibco).

\subsubsection{PCR do CDNA}

O cDNA foi amplificado utilizando-se $0,5 \mu \mathrm{l}$ da enzima Taq DNA polimerase (2,5U), $\mathrm{MgCl}_{2}(1,25 \mathrm{mM})$, dNTPs Mix (0,2mM), e os primers específicos descritos anteriormente na tabela 3 para a PFK, LDH, CS, CPT I e CPT II do músculo esquelético de rato (Rattus norvegicus).

O cDNA foi amplificado por $\mathrm{x}$ ciclos (PFK), $\mathrm{x}$ ciclos (LDH), $\mathrm{x}$ ciclos (CS), $\mathrm{x}$ ciclos (CPT I), e x ciclos (CPT II). O número de ciclos considerado ótimo foi aquele que resultou em maior amplificação sem que houvesse saturação. Cada ciclo consistiu na incubação das amostras por 35 segundos a $94^{\circ} \mathrm{C}$ (abertura); uma segunda incubação por 45 segundos a temperaturas variadas para cada primer (anelamento): $\mathrm{x}^{\circ} \mathrm{C}$ para a PFK, LDH, CS, CPT I e CPT II. Finalmente, foi realizada uma terceira incubação durante 60 segundos a $72^{\circ} \mathrm{C}$ (anelamento). O gene da RPL19 foi co-amplificado como controle interno da reação.

O produto obtido pela amplificação do PCR foi fracionado em gel de agarose a 1\%, utilizando um marcador de peso molecular, para confirmação do tamanho dos amplificados obtidos. O gel de agarose foi corado com brometo de etídio para a visualização da imagem em aparelho Typhoon System (Molecular Dynamics). As imagens obtidas foram quantificadas através do programa Image Quant $T M^{\circledR}$ (Molecular Dynamics). Para cada amostra foi calculada a relação de fluorescência das bandas dos genes estudados em relação ao controle RPL19. 


\section{RESULTADOS}

\subsection{Ingestão alimentar}

A ingestão alimentar de animais eutróficos sedentários (ES) (156,6 \pm 9,9g de ração/semana) e de eutróficos treinados (ET) (138,25 + 3,8g de ração/semana) não apresentou diferença estatística, como mostrado na figura 2.

Progressão da ingestão alimentar

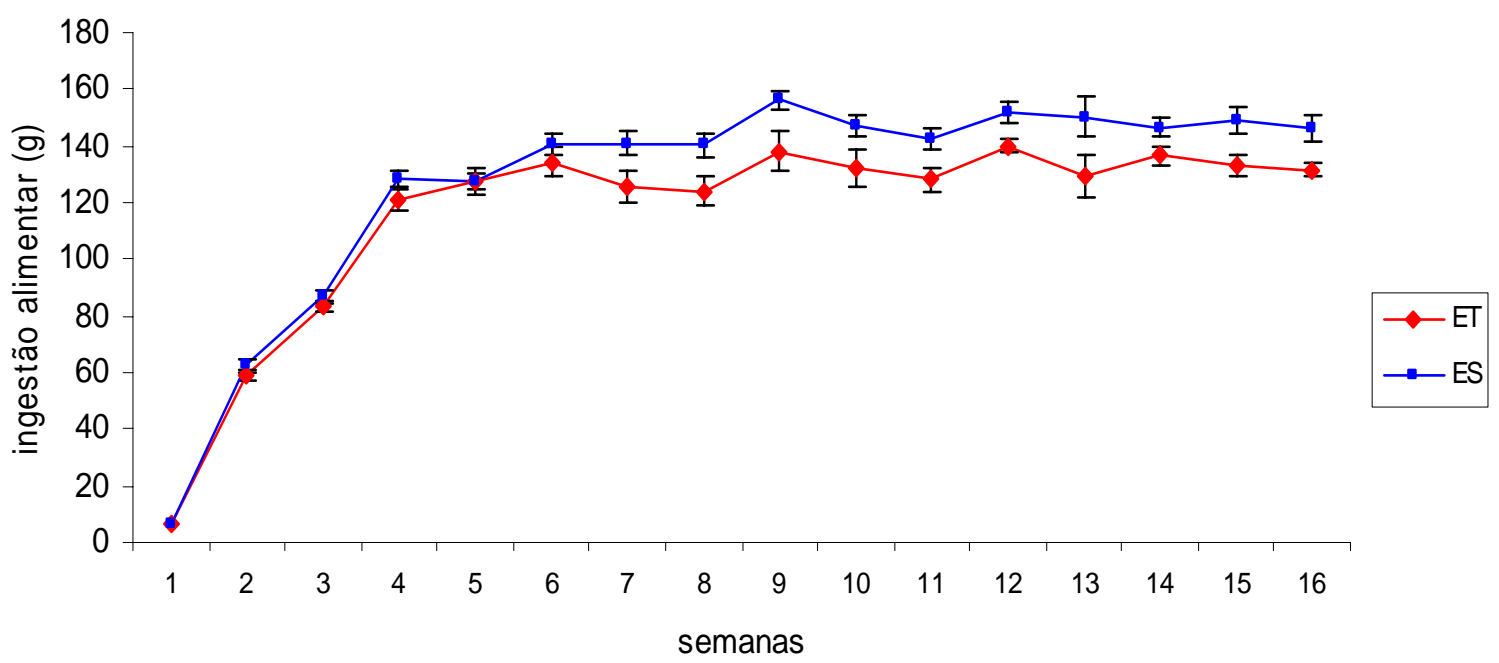

Figura 2. Acompanhamento da ingestão alimentar dos animais eutróficos (sedentários e treinados, ES (n=48) e ET (n=32), respectivamente) durante 16 semanas. Resultados representados em média e erro padrão. $\mathrm{p}<0,05$.

\subsection{Peso corporal}

A progressão do peso corporal dos animais está demonstrada na figura 3, e evidencia que, a partir da $2^{\mathrm{a}}$. semana, os animais desnutridos, tanto sedentários (DS) quanto treinados (DT) apresentaram um peso corporal significativamente menor do que os animais eutróficos, tanto sedentários (ES) quanto treinados (ET). 


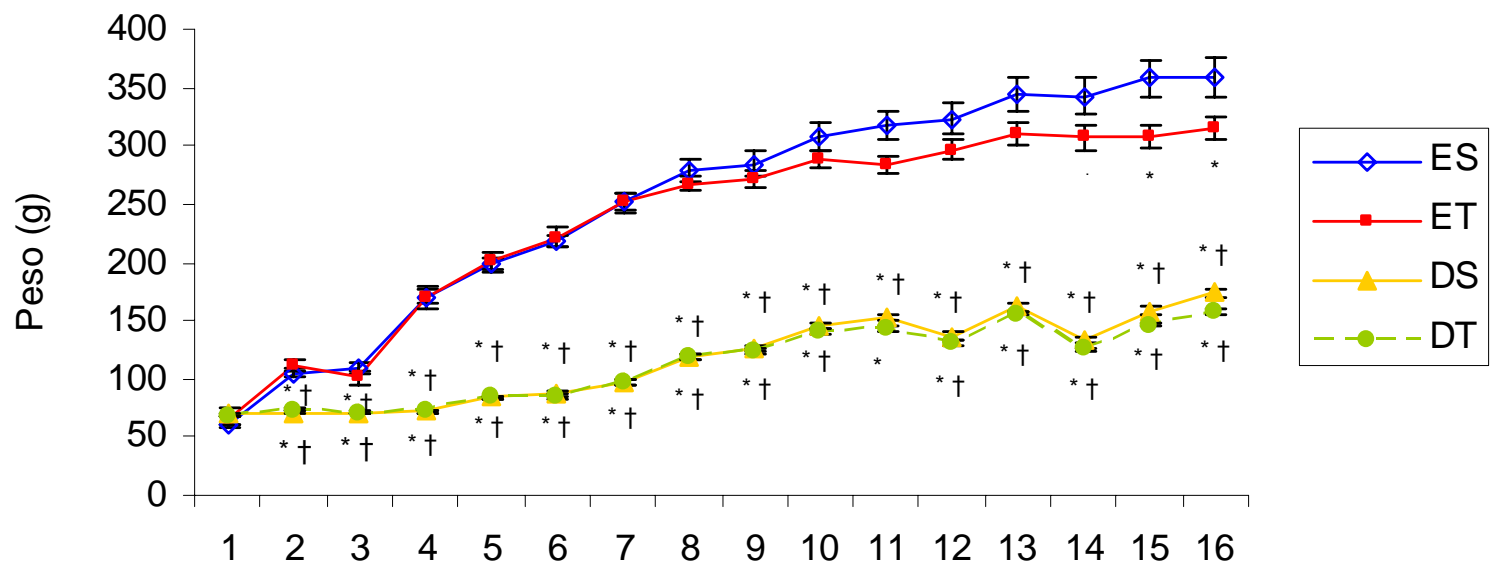

Semana

Figura 3. Progressão do peso corporal dos grupos eutrófico sedentário ( $E S$ - n=48), eutrófico treinado ( $E T$ $\mathrm{n}=32$ ), desnutrido sedentário ( $\mathrm{DS}-\mathrm{n}=48$ ) e desnutrido treinado ( $\mathrm{DT}-\mathrm{n}=32$ ) avaliado durante 16 semanas. Resultados representados em média e erro padrão. ${ }^{*} \mathrm{p}<0,05$ em relação ao grupo ES; † p $<0,05$ em relação ao grupo ET.

Nas últimas 3 semanas de tratamento, além dos grupos desnutridos sedentário (DS) e treinado (DT), os eutróficos treinados (ET), também apresentaram um peso corporal significativamente menor do que os animais eutróficos sedentários (ES). A figura 4 mostra a $16^{\text {a }}$. semana de tratamento, a mesma do sacrifício dos animais.

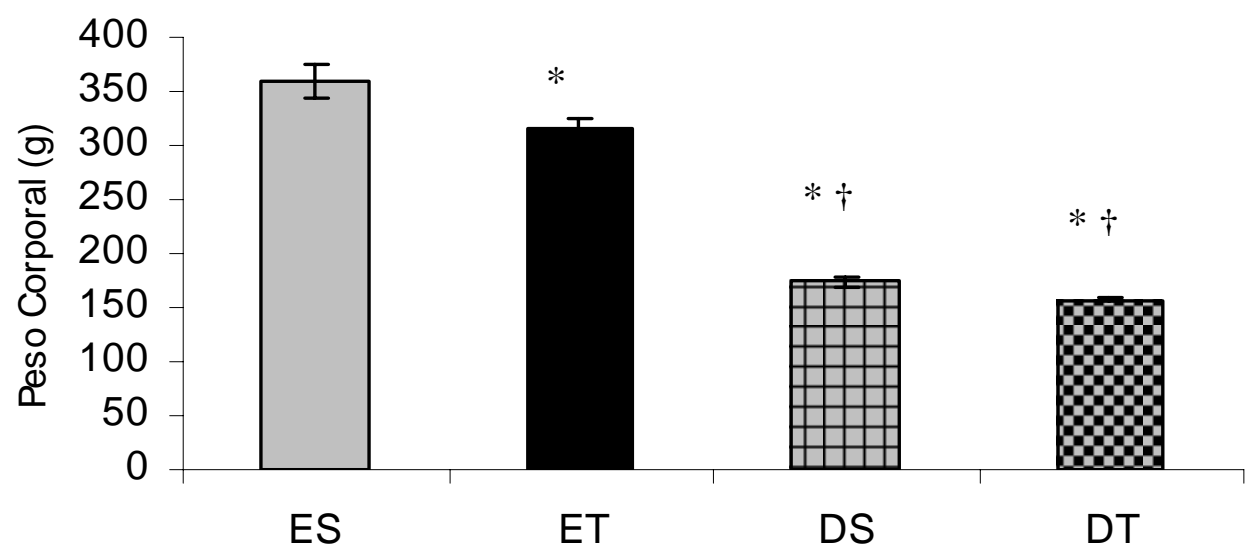

Figura 4. Peso corporal dos grupos eutrófico sedentário ( $E S-n=48$ ), eutrófico treinado ( $E T-n=32$ ), desnutrido sedentário (DS - $n=48$ ), desnutrido treinado ( $D T-n=32$ ) na $16^{\text {a }}$. semana de tratamento. Resultados representados em média e erro padrão. * ${ }^{*}<0,05$ em relação ao grupo ES. $\dagger p<0,05$ em relação ao ET. 


\subsection{Peso dos tecidos}

O peso absoluto e relativo (porcentagem do peso corporal total) do sóleo, exetensor digitório longo (EDL), gastrocnêmio (gastro) e fígado estão descritos na tabela 4 e 5, respectivamente. O peso absoluto dos tecidos avaliados apresentou-se significativamente diminuído nos desnutridos (DS e DT), em relação aos eutróficos (ES e ET), porém em relação ao peso corporal, nem todos mostraram tal redução. O peso absoluto do EDL, gastrocnêmio e fígado do ET também diminuiu significativamente em relação ao ES. Já as alterações apresentadas no valor de peso relativo foram diferentes das alterações no peso absoluto. $\mathrm{O}$ peso do músculo sóleo sofreu alteração apenas no DT, aumentando em relação ao ES, ET e DS. A massa do músculo EDL do ET diminuiu significativamente em relação ao ES, porém, a do mesmo músculo do DT não diminuiu em relação ao DS. O peso relativo do músculo gastrocnêmio diminuiu no DS em relação ao ES e, mostrou-se reduzido no DT em relação ao ES e ET. Já o fígado não sofreu alterações no peso relativo em função da desnutrição, do exercício, ou da associação dos protocolos.

Tabela 4. Peso absoluto (g) dos músculos esqueléticos e do fígado.

\begin{tabular}{ccccc}
\hline & ES & ET & DS & DT \\
\hline Sóleo & $0,12 \pm 0,004$ & $0,11 \pm 0,006$ & $0,061 \pm 0,004^{*} \dagger$ & $0,065 \pm 0,003^{*} \dagger$ \\
EDL & $0,15 \pm 0,005$ & $0,12 \pm 0,006 *$ & $0,079 \pm 0,003^{*} \dagger$ & $0,071 \pm 0,001^{*} \dagger$ \\
Gastro & $1,53 \pm 0,063$ & $1,36 \pm 0,066^{*}$ & $0,805 \pm 0,046^{*} \dagger$ & $0,74 \pm 0,007^{*} \dagger$ \\
Fígado & $10,46 \pm 1,35$ & $9,04 \pm 1,16^{*}$ & $5,06 \pm 0,54^{*} \dagger$ & $4,50 \pm 0,72^{*} \dagger$ \\
\hline
\end{tabular}

Peso absoluto (g) dos músculos sóleo, extensor digitório longo (EDL), gastrocnêmio (gastro) e do fígado dos grupos eutrófico sedentário ( $E S-n=12)$, eutrófico treinado $(E T-n=8)$, desnutrido sedentário $(D S-n=12)$, desnutrido treinado (DT $-\mathrm{n}=8$ ). Resultados representados em média e erro padrão. ${ }^{*} \mathrm{p}<0,05$ em relação ao grupo ES; †p<0,05 em relação ao ET; $\ddagger$ p<0,05 em relação ao DS. 
Tabela 5. Peso relativo (\%) dos músculos esqueléticos e do fígado.

\begin{tabular}{ccccc}
\hline & ES & ET & DS & DT \\
\hline Sóleo & $0,032 \pm 0,003$ & $0,035 \pm 0,004$ & $0,035 \pm 0,006$ & $0,042 \pm 0,004^{*} \dagger \neq$ \\
EDL & $0,041 \pm 0,005$ & $0,036 \pm 0,006^{*}$ & $0,045 \pm 0,003^{*} \dagger$ & $0,046 \pm 0,004^{*} \dagger$ \\
Gastro & $0,468 \pm 0,61$ & $0,46 \pm 0,068$ & $0,515 \pm 0,039^{*}$ & $0,551 \pm 0,054^{*} \dagger$ \\
& & & & \\
Fígado & $2,89 \pm 0,33$ & $2,75 \pm 0,26$ & $2,91 \pm 0,31$ & $2,91 \pm 0,37$
\end{tabular}

Peso relativo (\% - porcentagem do peso corporal total) dos músculos sóleo, extensor digitório longo (EDL), gastrocnêmio (gastro) e do fígado dos grupos eutrófico sedentário ( $E S-n=12$ ), eutrófico treinado ( $E T-n=8)$, desnutrido sedentário (DS - n=12), desnutrido treinado (DT - n=8). Resultados representados em média e erro padrão. ${ }^{*} \mathrm{p}<0,05$ em relação ao grupo ES; †p<0,05 em relação ao ET; $\ddagger$ p $<0,05$ em relação ao DS.

A avaliação do peso absoluto e relativo dos tecidos adiposos está descrita nas tabelas 6 e 7, respectivamente. O peso absoluto dos depósitos de tecido adiposo retroperitoneal (TARP), epididimal (TAE) e mesentérico (TAME) foi reduzido significativamente nos animais desnutridos sedentários (DS) e treinados (DT) em relação, tanto aos eutróficos sedentários (ES) quanto aos treinados (ET). O peso relativo do TARP e do TAE também apresentou o mesmo comportamento, com uma redução significativa nos animais desnutridos sedentários (DS) e treinados (DT) em relação, tanto aos eutróficos sedentários (ES) quanto aos treinados (ET). O peso relativo do TAME não apresentou o mesmo resultado, havendo uma redução significativa desse depósito de gordura nos animais desnutridos sedentários (DS) e treinados (DT) apenas em relação aos eutróficos sedentários (ES).

Tabela 6. Peso absoluto (g) dos tecidos adiposos.

\begin{tabular}{ccccc}
\hline & ES & ET & DS & DT \\
\hline TARP & $3,52 \pm 0,31$ & $2,57 \pm 0,31^{*}$ & $0,53 \pm 0,09 * \dagger$ & $0,38 \pm 0,07^{*} \dagger$ \\
TAE & $3,87 \pm 0,25$ & $3,41 \pm 0,37$ & $1,16 \pm 0,15^{*} \dagger$ & $1,01 \pm 0,10^{*} \dagger$ \\
& & & & \\
TAME & $3,49 \pm 0,30$ & $2,98 \pm 0,40$ & $1,14 \pm 0,13^{*} \dagger$ & $1,09 \pm 0,05^{*} \dagger$
\end{tabular}

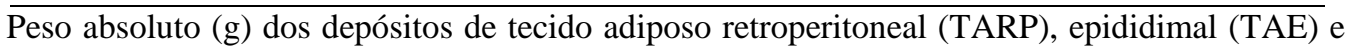
mesentérico (TAME) dos grupos eutrófico sedentário (ES - n=12), eutrófico treinado (ET $\mathrm{n}=8$ ), desnutrido sedentário (DS $-\mathrm{n}=12$ ), desnutrido treinado (DT $-\mathrm{n}=8$ ). Resultados representados em média e erro padrão. ${ }^{*} \mathrm{p}<0,05$ em relação ao grupo $\mathrm{ES} ; \mathrm{p}<<0,05$ em relação ao ET; $\ddagger \mathrm{p}<0,05$ em relação ao DS. 
Tabela 7. Peso relativo (\%) dos tecidos adiposos.

\begin{tabular}{ccccc}
\hline & ES & ET & DS & DT \\
\hline TARP & $1,00 \pm 0,10$ & $0,82 \pm 0,10$ & $0,31 \pm 0,06^{*} \dagger$ & $0,24 \pm 0,04^{*} \dagger$ \\
TAE & $1,09 \pm 0,08$ & $1,09 \pm 0,12$ & $0,68 \pm 0,10^{*} \dagger$ & $0,64 \pm 0,07^{*} \dagger$ \\
& & & \\
TAME & $0,99 \pm 0,10$ & $0,95 \pm 0,13$ & $0,65 \pm 0,07^{*}$ & $0,69 \pm 0,05^{*}$
\end{tabular}

Peso relativo (\% - porcentagem do peso corporal total) dos depósitos de tecido adiposo retroperitoneal (TARP), epididimal (TAE) e mesentérico (TAME) dos grupos eutrófico sedentário ( $E S-n=12)$, eutrófico treinado $(E T-n=8)$, desnutrido sedentário (DS $-n=12$ ), desnutrido treinado $(\mathrm{DT}-\mathrm{n}=8)$. Resultados representados em média e erro padrão. ${ }^{*} \mathrm{p}<0,05 \mathrm{em}$ relação ao grupo ES; $\dagger p<0,05$ em relação ao $\mathrm{ET} ; \ddagger \mathrm{p}<0,05$ em relação ao DS.

\subsection{Conteúdo de gordura e proteína na carcaça}

O conteúdo total de gordura dos animais, assim como o conteúdo de proteínas estão descritos na tabela 8 e, ilustrados nas figuras 5 e 6, respectivamente. O grupo DS apresentou significativa diminuição, de 63,1\%, no conteúdo de gordura corporal total em relação ao ES, assim como, no DT houve redução de $81 \%$ e $84,46 \%$ em relação ao ES e ET, respectivamente. Já o conteúdo total de proteína corporal diminuiu significativamente no grupo DT em relação ao ES, ET e DS.

Tabela 8. Conteúdo de gordura (g) e proteínas (mg/ml) na carcaça.

\begin{tabular}{|c|c|c|c|c|}
\hline & ES & ET & DS & DT \\
\hline Gordura (g) & $23,12 \pm 4,12$ & $28,31 \pm 5,37$ & $7,61 \pm 0,88 * \dagger$ & $4,40 \pm 0,26 * \dagger \ddagger$ \\
\hline Proteína (mg/ml) & $56,36 \pm 2,44$ & $45,64 \pm 4,79$ & $55,29 \pm 3,65$ & $25,08 \pm 7,15 * \dagger \ddagger$ \\
\hline
\end{tabular}




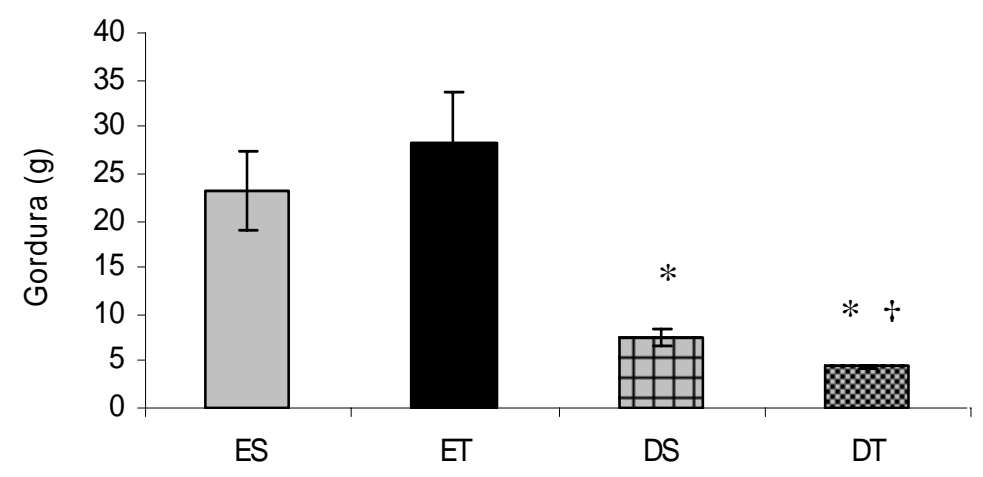

Figura 5. Conteúdo total de gordura na carcaça (g) dos grupos eutrófico sedentário (ES $\mathrm{n}=8$ ), eutrófico treinado ( $\mathrm{ET}-\mathrm{n}=8$ ), desnutrido sedentário ( $\mathrm{DS}-\mathrm{n}=8$ ), desnutrido treinado $(\mathrm{DT}-\mathrm{n}=8)$. Resultados representados em média e erro padrão. ${ }^{*} \mathrm{p}<0,05$ em relação ao grupo ES; †p<0,05 em relação ao ET; $\ddagger$ p $<0,05$ em relação ao DS.

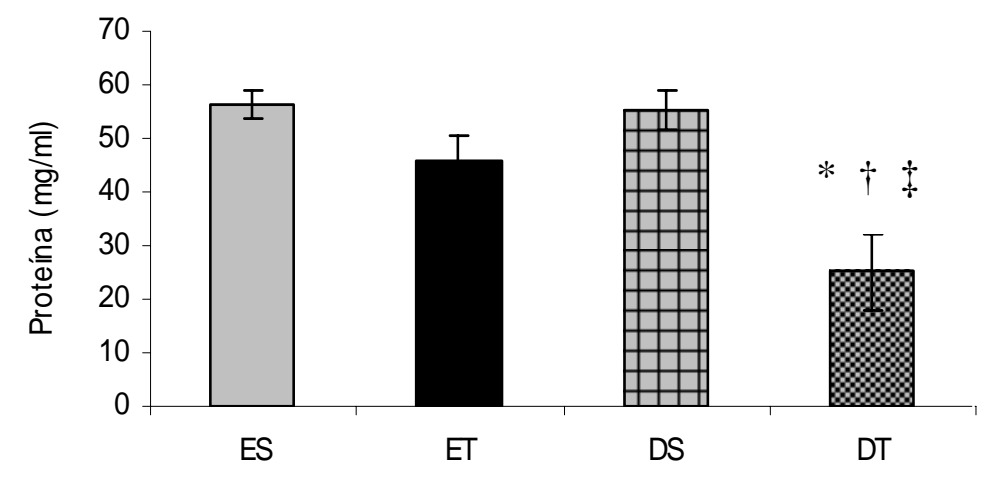

Figura 6. Conteúdo total de proteínas na carcaça $(\mathrm{mg} / \mathrm{ml})$ dos grupos eutrófico sedentário $(E S-n=8)$, eutrófico treinado $(E T-n=8)$, desnutrido sedentário ( $D S-n=8$ ), desnutrido treinado (DT - $\mathrm{n}=8$ ). Resultados representados em média e erro padrão. ${ }^{*} \mathrm{p}<0,05$ em relação ao grupo ES; $\nmid \mathrm{p}<0,05$ em relação ao ET; $\ddagger \mathrm{p}<0,05$ em relação ao DS.

A quantidade de massa gorda e de massa magra corporal está demonstrada graficamente nas figuras 7 e 8 , respectivamente. O percentual de gordura corporal foi significativamente reduzido no DS (-41,7\%) em relação ao ES e, no DT, em relação ao ES (- 
63,8\%) e ET (-71,3\%). O percentual de massa magra corporal aumentou significativamente no grupo DS em relação ao ES e, no grupo DT em relação ao ES e ET.

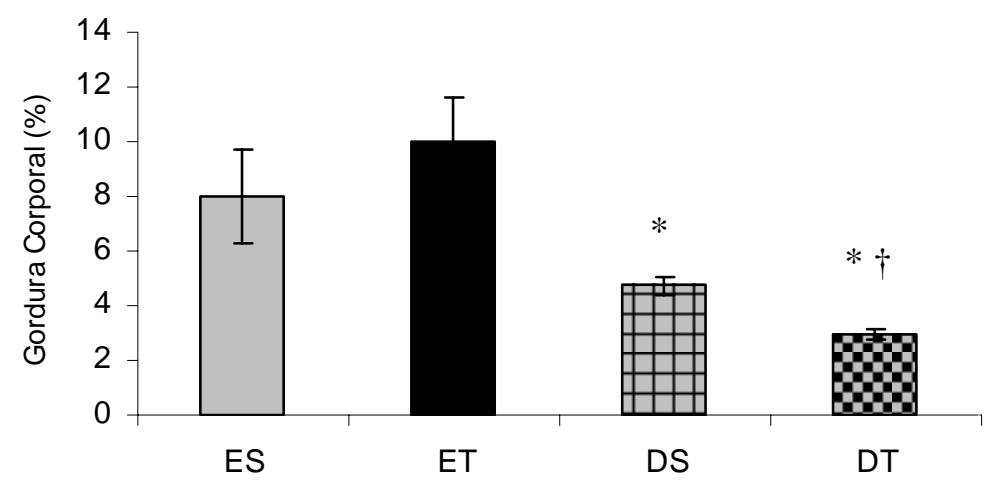

Figura 7. Gordura corporal percentual dos grupos eutrófico sedentário ( $E S-n=8)$, eutrófico treinado (ET $-n=8$ ), desnutrido sedentário (DS $-n=8$ ), desnutrido treinado (DT $-n=8$ ). Resultados representados em média e erro padrão. ${ }^{*} \mathrm{p}<0,05$ em relação ao grupo ES. $\dagger p<0,05$ em relação ao ET. $\ddagger$ p $<0,05$ em relação ao DS.

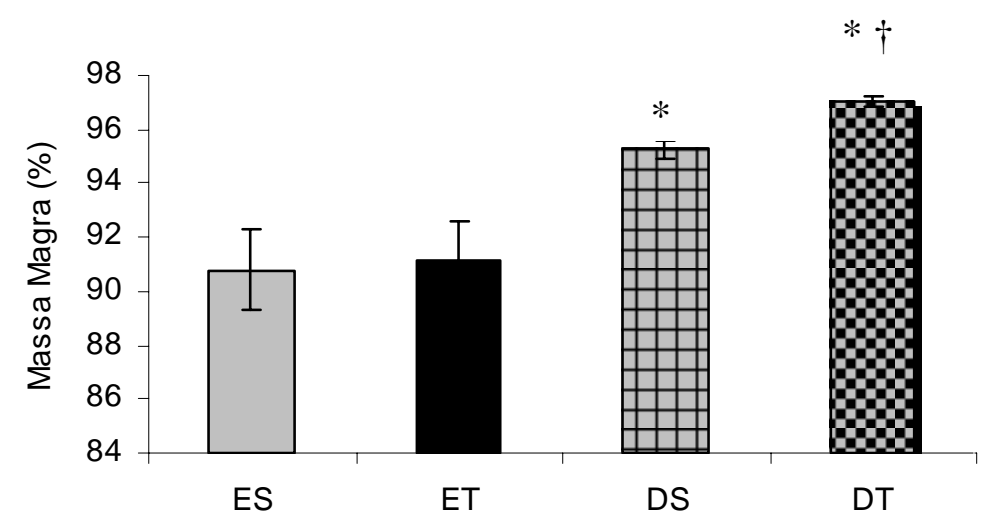

Figura 8. Massa magra percentual dos grupos eutrófico sedentário ( $E S-\mathrm{n}=8$ ), eutrófico treinado (ET $-n=8$ ), desnutrido sedentário (DS $-n=8$ ), desnutrido treinado (DT $-n=8$ ). Resultados representados em média e erro padrão. ${ }^{*} \mathrm{p}<0,05$ em relação ao grupo ES. $\dagger \mathrm{p}<0,05$ em relação ao ET. $¥ \mathrm{p}<0,05$ em relação ao DS.

\subsection{Proteína sérica}

A figura 9 ilustra graficamente a concentração de proteína no soro nos grupos eutrófico sedentário (ES), 73,62 \pm 1,6mg/ml, eutrófico treinado (ET), 75,91 \pm 1,3mg/ml, desnutrido sedentário (DS), 72,95 \pm 2,1mg/ml, e desnutrido treinado (DT), 69,94 \pm 1,8mg/ml. Não houve diferença significativa entre os grupos. 


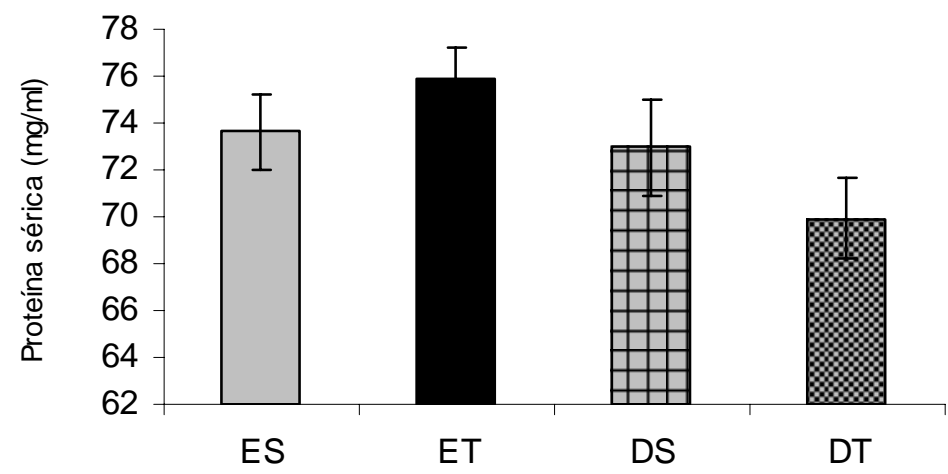

Figura 9. Concentração de proteína no soro dos grupos eutrófico sedentário ( $E S-n=12$ ), eutrófico treinado (ET $-n=8$ ), desnutrido sedentário ( $D S-n=12$ ), desnutrido treinado (DT $-\mathrm{n}=8$ ). Resultados representados em média e erro padrão. $\mathrm{p}<0,05$.

\subsection{Concentração sangüínea de glicose e insulina}

Na figura 10 está ilustrada a glicemia dos grupos eutrófico sedentário (ES), 129,12 \pm 14,93mg/dl, eutrófico treinado (ET), 120,71 \pm 15,94mg/dl, desnutrido sedentário (DS), 92,37 $\pm 12,95 \mathrm{mg} / \mathrm{dl}$ e, desnutrido treinado (DT), 117,18 \pm 38,40mg/dl. Nota-se uma significativa menor concentração de glicose plasmática no grupo DT em relação aos grupos ES e ET e, uma maior glicemia significativa em relação no grupo DT em relação ao DS.

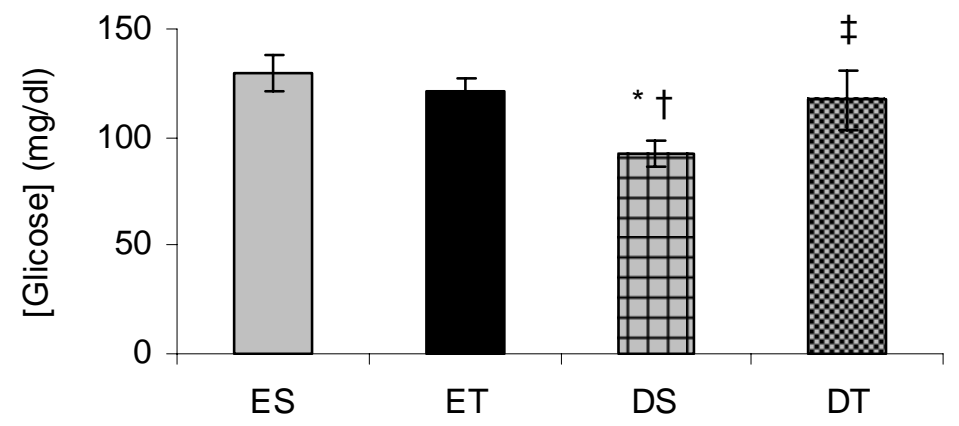

Figura 10. Glicemia (mg/dl) nos grupos eutrófico sedentário ( $\mathrm{ES}-\mathrm{n}=8)$, eutrófico treinado $(E T-n=8)$, desnutrido sedentário (DS $-n=8$ ), desnutrido treinado (DT $-n=8$ ). Resultados representados em média e erro padrão. ${ }^{*} \mathrm{p}<0,05$ em relação ao grupo $\mathrm{ES}$. $\dagger \mathrm{p}<0,05$ em relação ao ET. $\ddagger$ p<0,05 em relação ao DS. 
Na figura 11 está representada graficamente a insulinemia dos grupos eutrófico

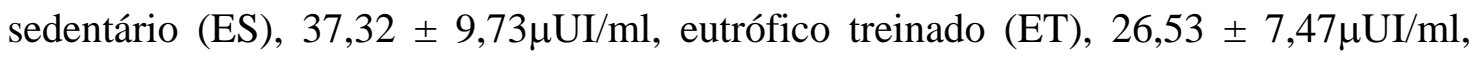
desnutrido sedentário (DS), 32,6 \pm 9,32 $\mu \mathrm{UI} / \mathrm{ml}$ e, desnutrido treinado (DT), 10,42 \pm $4,37 \mu \mathrm{UI} / \mathrm{ml}$. Estatisticamente, não houve diferença entre os grupos apesar da diminuição notada no grupo DT.

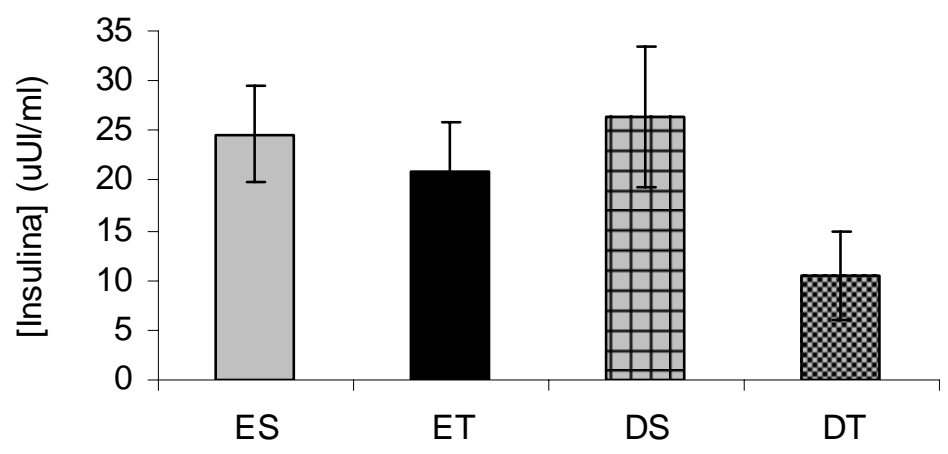

Figura 11. Insulinemia $(\mu \mathrm{UI} / \mathrm{ml})$ nos grupos eutrófico sedentário ( $E S-\mathrm{n}=8$ ), eutrófico treinado $(E T-n=8)$, desnutrido sedentário ( $D S-n=8$ ), desnutrido treinado (DT $-n=8$ ). Resultados representados em média e erro padrão. ${ }^{*} \mathrm{p}<0,05$ em relação ao grupo ES. $\dagger \mathrm{p}<0,05$ em relação ao ET. $¥ \mathrm{p}<0,05$ em relação ao DS. $\mathrm{p}<0,05$.

A figura 12 demonstra a relação insulina/glicose na qual percebe-se uma redução significativa no grupo desnutrido treinado (DT) em relação a todos os outros grupos.

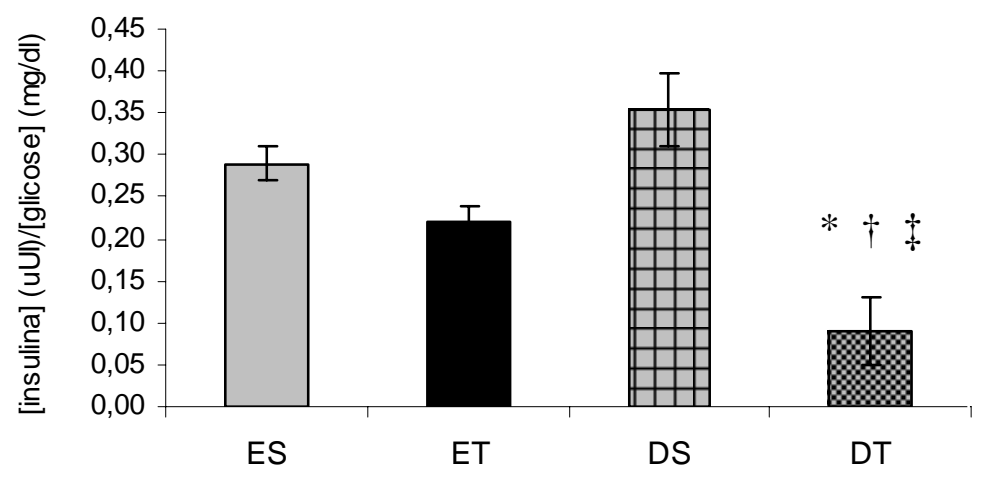

Figura 12. Relação insulina/glicose ( [insulina] ( $\mu \mathrm{UI} / \mathrm{ml}) /$ [glicose] (mg/dl) ) dos grupos eutrófico sedentário $(\mathrm{ES}-\mathrm{n}=8$ ), eutrófico treinado $(\mathrm{ET}-\mathrm{n}=8$ ), desnutrido sedentário (DS $\mathrm{n}=8$ ), desnutrido treinado ( $\mathrm{DT}-\mathrm{n}=8$ ). Resultados representados em média e erro padrão. ${ }^{*} \mathrm{p}<0,05$ em relação ao grupo ES. $\nmid \mathrm{p}<0,05$ em relação ao $\mathrm{ET}$. $\ddagger \mathrm{p}<0,05$ em relação ao DS. 


\subsection{Concentração de glicogênio muscular}

Os resultados da concentração de glicogênio avaliado no músculo gastrocnêmio, em suas porções branca e vermelha, estão demonstrados nas figuras 13 e 14 , respectivamente.

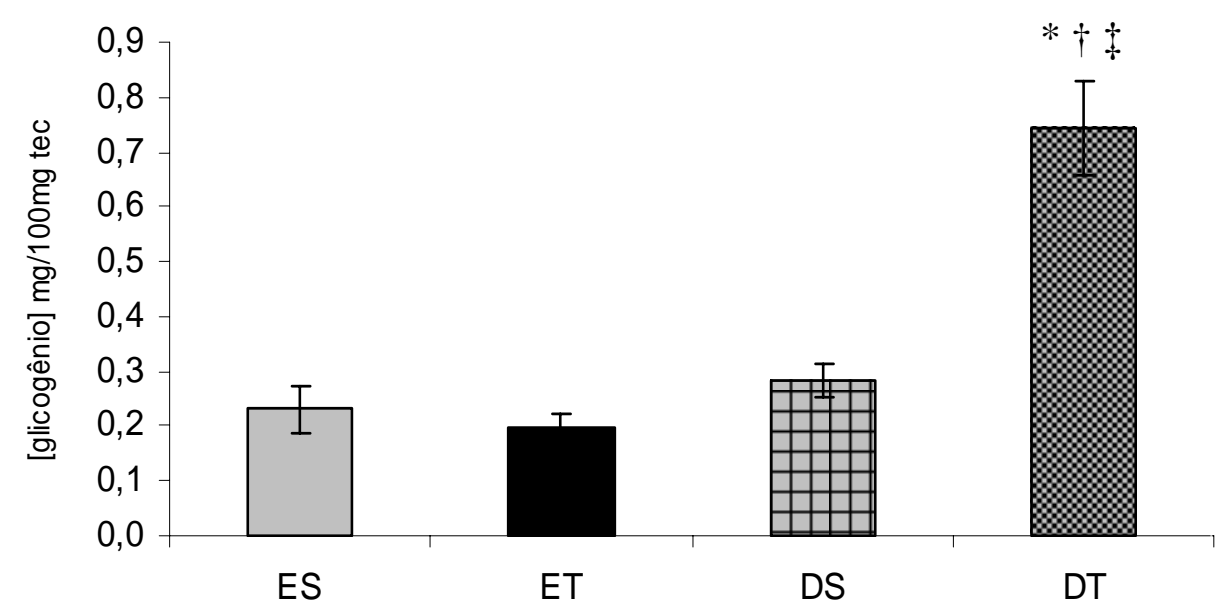

Figura 13. Concentração de glicogênio (mg/100mg de tecido) na porção branca do músculo esquelético gastrocnêmio dos grupos eutrófico sedentário ( $E S-n=8$ ), eutrófico treinado (ET $n=7$ ), desnutrido sedentário (DS $-n=8$ ), desnutrido treinado ( $D T-n=6$ ). Resultados representados em média e erro padrão. ${ }^{*} \mathrm{p}<0,05$ em relação ao grupo ES. $\dagger p<0,05$ em relação ao ET. $\ddagger \mathrm{p}<0,05$ em relação ao DS.

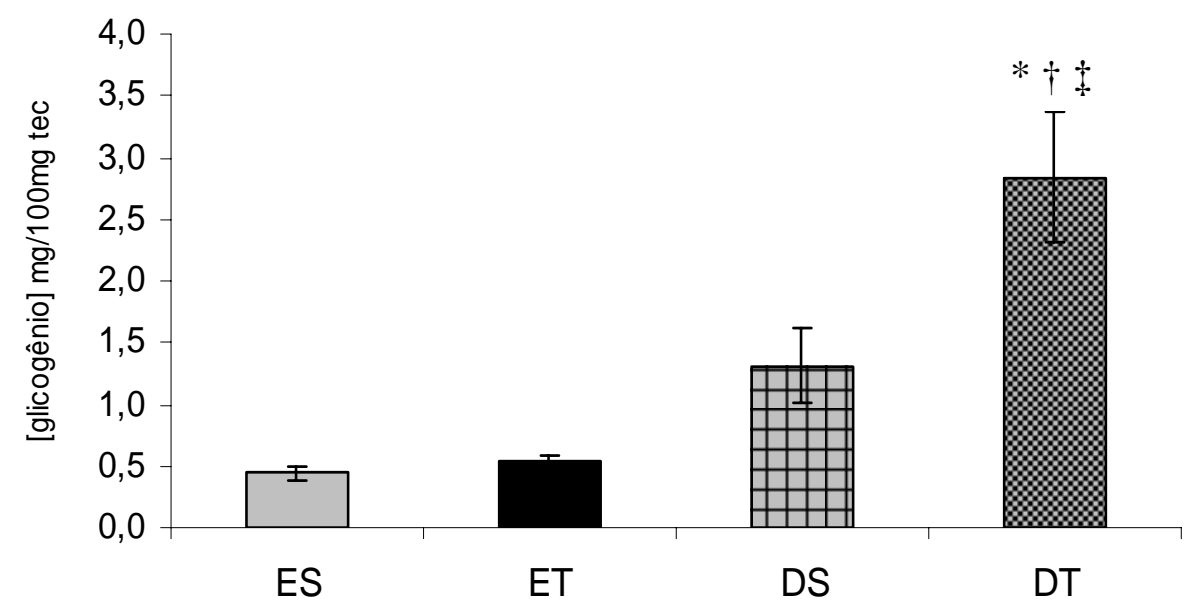

Figura 14. Concentração de glicogênio (mg/100mg de tecido) na porção vermelha do músculo esquelético gastrocnêmio dos grupos eutrófico sedentário ( $E S$ - n=8), eutrófico treinado (ET $n=7$ ), desnutrido sedentário (DS $-n=8$ ), desnutrido treinado ( $D T-n=6$ ). Resultados representados em média e erro padrão. ${ }^{*} \mathrm{p}<0,05$ em relação ao grupo ES. $\dagger p<0,05$ em relação ao ET. $\ddagger \mathrm{p}<0,05$ em relação ao DS. 
Os valores da concentração de glicogênio na porção branca do gastrocnêmio encontraram-se significativamente maiores no grupo desnutrido treinado (DT), 0,743 \pm 0,215mg/100mg de tecido em relação aos grupos eutrófico sedentário (ES), 0,232 \pm 0,113, eutrófico treinado (ET), 0,196 \pm 0,063, e desnutrido sedentário (DS), 0,282 \pm 0,082. Na porção vermelha do gastrocnêmio a concentração de glicogênio demonstrou o mesmo comportamento, com um significativo aumento no grupo desnutrido treinado (DT), 2,842 \pm 0,522mg/100mg de tecido, em relação aos grupos eutrófico sedentário (ES), 0,442 $\pm 0,064$, eutrófico treinado (ET), 0,540 \pm 0,051, e desnutrido sedentário (DS), 1,313 $\pm 0,300$.

\subsection{Teste de desempenho}

O grupo desnutrido treinado (DT) apresentou um significativo melhor desempenho de corrida, tanto com um maior tempo até a exaustão quanto com uma maior velocidade atingida no momento da fadiga, do que os grupos eutróficos sedentário (ES) e treinado (ET) e desnutrido sedentário (DS).

\subsubsection{Tempo até a exaustão}

O tempo até a exaustão está demonstrado na figura 15 que ilustra quanto tempo cada grupo, em média, levou até atingir a fadiga. O grupo desnutrido treinado (DT) demorou 36,82 \pm 2,03 minutos até entrar em exaustão, enquanto os grupos eutrófico sedentário (ES), 11,13 \pm 1,53min, eutrófico treinado (ET), 23,43 \pm 3,15min e, desnutrido sedentário (DS), 10,27 \pm 1,18min, demoraram significativamente menos tempo para chegar à exaustão. 


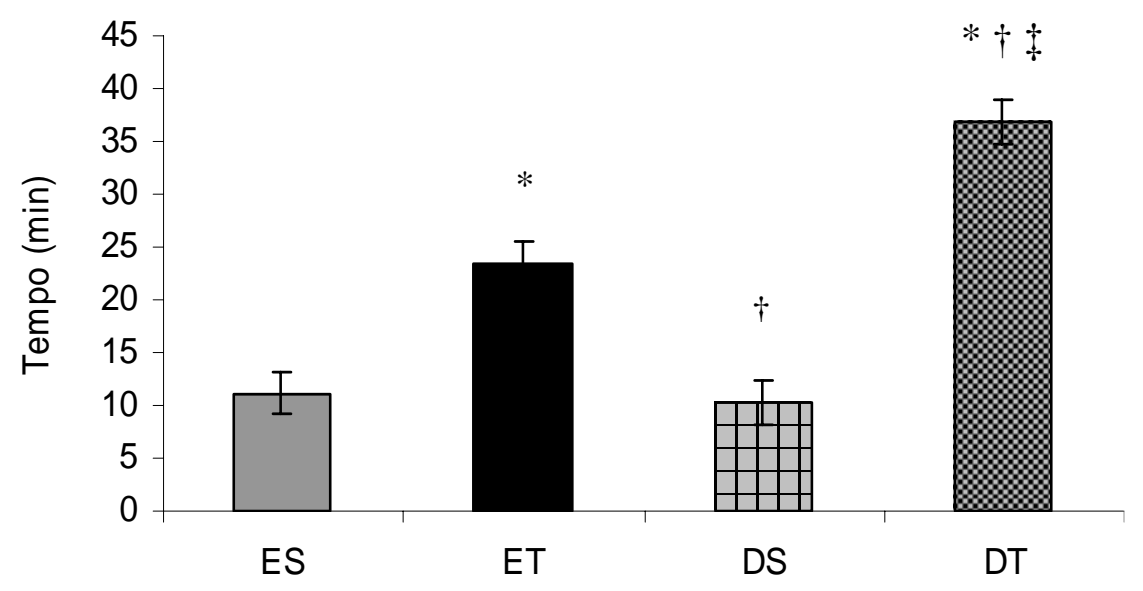

Figura 15. Tempo até a exaustão, em minutos (min), dos grupos eutrófico sedentário (ES $\mathrm{n}=16$ ), eutrófico treinado ( $\mathrm{ET}-\mathrm{n}=16$ ), desnutrido sedentário ( $\mathrm{DS}-\mathrm{n}=16$ ), desnutrido treinado (DT $-\mathrm{n}=16$ ). Resultados representados em média e erro padrão. * ${ }^{*}<0,05$ em relação ao grupo ES. $\dagger p<0,05$ em relação ao ET. $\ddagger \mathrm{p}<0,05$ em relação ao DS.

\subsubsection{Velocidade atingida na exaustão}

A velocidade no momento da exaustão está demonstrada na figura 16, que ilustra qual velocidade cada grupo atingiu até o exato momento que entrou em fadiga. O grupo desnutrido treinado (DT) atingiu a velocidade de 48,75 $\pm 2,39 \mathrm{~m} / \mathrm{min}$ até entrar em exaustão, enquanto os grupos eutrófico sedentário (ES), 22,50 \pm 1,44m/min, eutrófico treinado (ET), 38,33 \pm 3,54m/min e, desnutrido sedentário (DS), 22,50 $\pm 1,44 \mathrm{~m} / \mathrm{min}$, atingiram uma velocidade significativamente menor no momento em que entraram em fadiga.

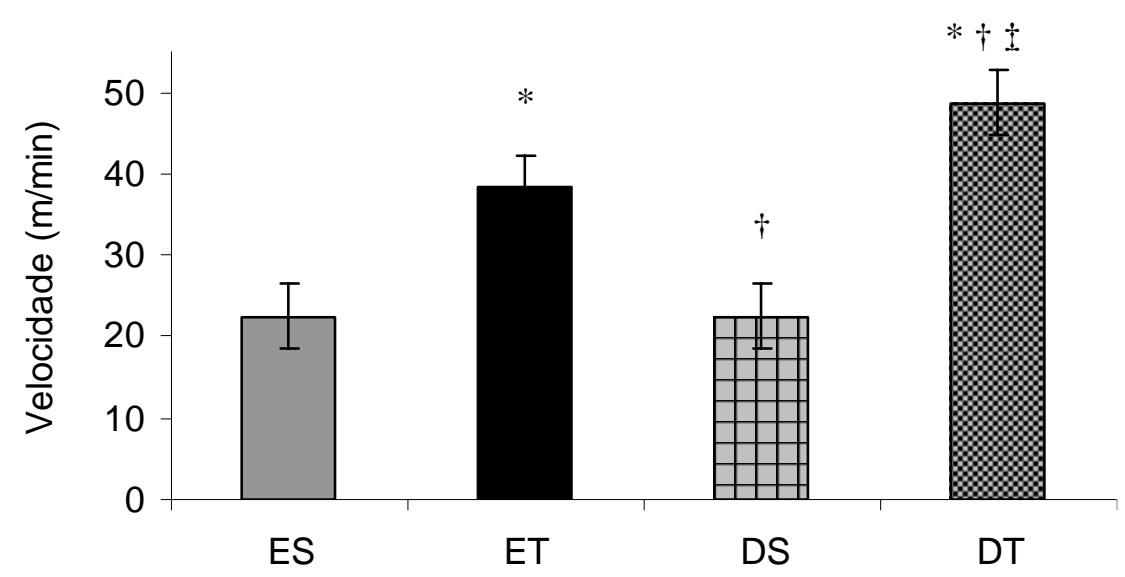

Figura 16. Velocidade de exaustão $(\mathrm{m} / \mathrm{min})$ dos grupos eutrófico sedentário ( $\mathrm{ES}-\mathrm{n}=16)$, eutrófico treinado (ET $-\mathrm{n}=16$ ), desnutrido sedentário (DS $-\mathrm{n}=16$ ), desnutrido treinado (DT $\mathrm{n}=16$ ) Resultados representados em média e erro padrão. ${ }^{*} \mathrm{p}<0,05$ em relação ao grupo ES. $\dagger p<0,05$ em relação ao ET. $\ddagger p<0,05$ em relação ao DS. 


\subsection{Consumo máximo de oxigênio ( $\left.\mathrm{VO}_{2 m a ́ x}\right)$}

O consumo máximo de oxigênio $\left(\mathrm{VO}_{2 \text { máx }}\right)$ realizado antes do período de treinamento está ilustrado na figura 17. Os resultados demonstraram não haver diferença significativa entre os grupos eutrófico sedentário (ES), 27,05 $\pm 2,53 \mathrm{ml} / \mathrm{kg} / \mathrm{min}$, eutrófico treinado (ET), 21,38 \pm 1,57, desnutrido sedentário (DS), 26,45 \pm 1,43, e desnutrido treinado (DT), 26,85 \pm 3,03.

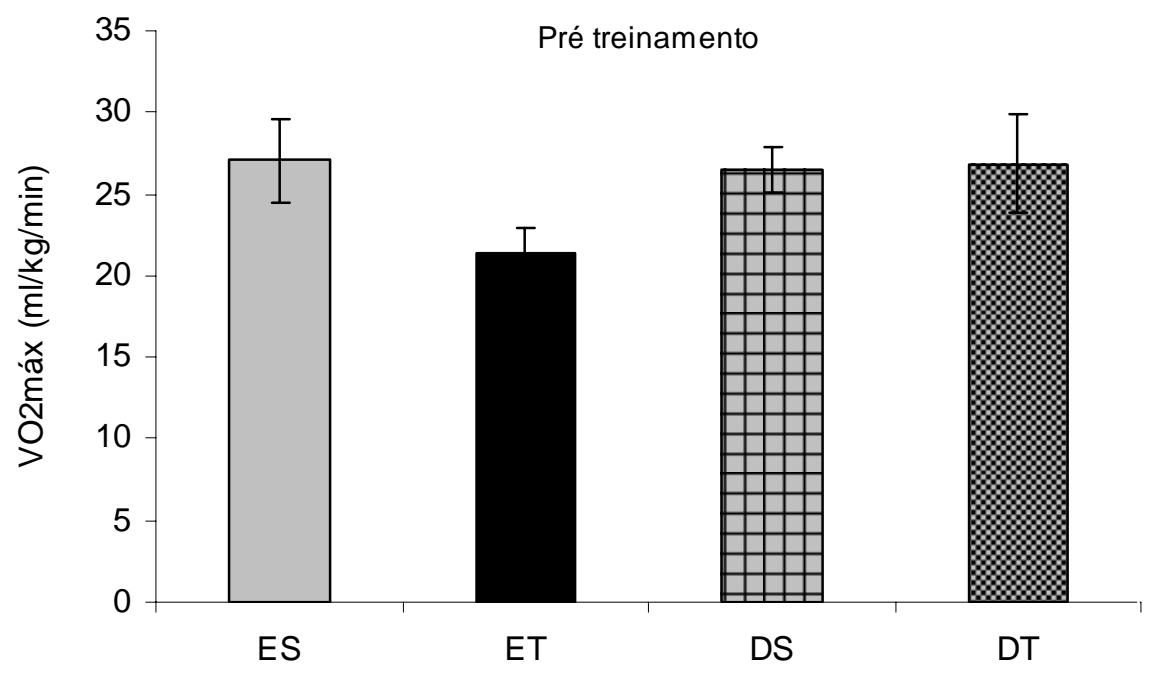

Figura 17. $\mathrm{VO}_{2 \text { máx }}(\mathrm{ml} / \mathrm{kg} / \mathrm{min})$ realizado antes do período de treinamento dos grupos eutrófico sedentário ( $E S-n=16)$, eutrófico treinado ( $E T-n=16$ ), desnutrido sedentário ( $D S-n=16$ ), desnutrido treinado (DT - n=16) Resultados representados em média e erro padrão. $\mathrm{p}<0,05$.

Já o $\mathrm{VO}_{2 \text { máx }}$ após o período de 10 semanas de treinamento apresentou resultado diferente e está ilustrado na figura 18. Os resultados demonstraram que o grupo desnutrido treinado (DT) apresentou um $\mathrm{VO}_{2 \operatorname{máx}}$ significativamente maior, 41,90 $\pm 1,72 \mathrm{ml} / \mathrm{kg} / \mathrm{min}$, do que os grupos eutrófico sedentário (ES), 34,59 \pm 1,89, eutrófico treinado (ET), 32,45 $\pm 2,27$, e desnutrido sedentário (DS), 34,31 \pm 1,86. 


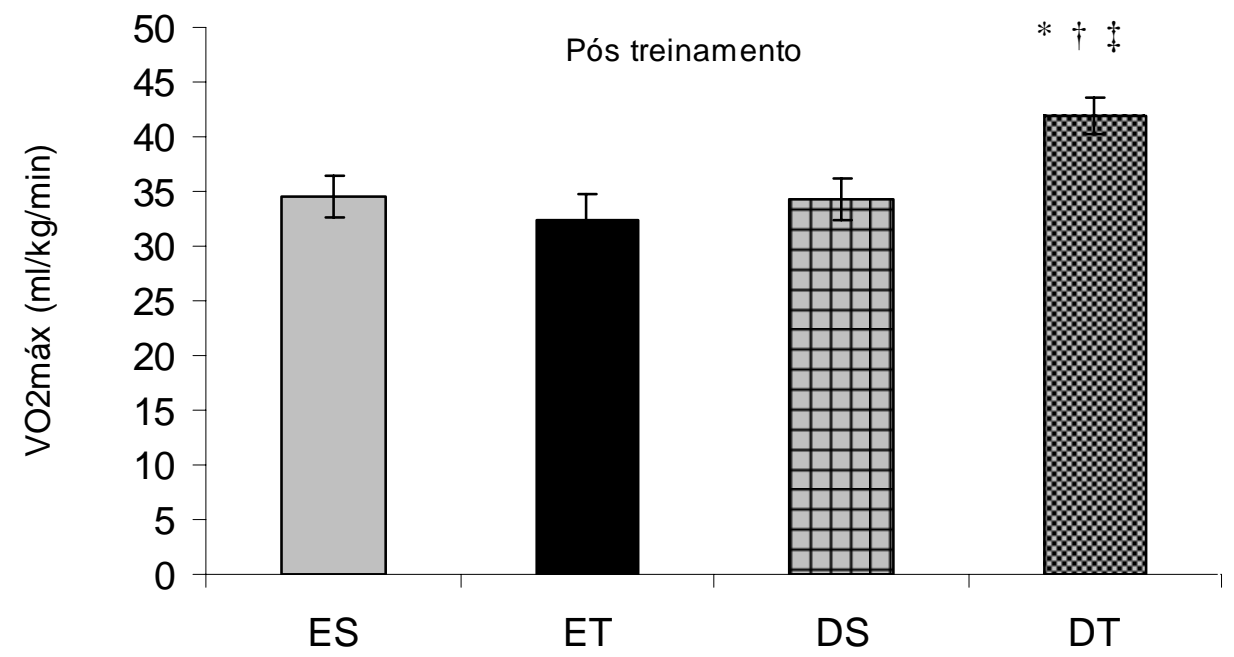

Figura 18. $\mathrm{VO}_{2 \text { máx }}(\mathrm{ml} / \mathrm{kg} / \mathrm{min})$ realizado após o período de 10 semanas de treinamento dos grupos eutrófico sedentário ( $E S-n=16$ ), eutrófico treinado ( $E T-n=16$ ), desnutrido sedentário ( $D S-n=16$ ), desnutrido treinado ( $\mathrm{DT}-\mathrm{n}=16$ ). Resultados representados em média e erro padrão. ${ }^{*} \mathrm{p}<0,05$ em relação ao grupo ES. $\nmid p<0,05$ em relação ao ET. $\ddagger p<0,05$ em relação ao DS.

\subsection{Análise da expressão gênica de proteínas musculares por RT-PCR}

Os resultados da expressão gênica de enzimas no músculo extensor digitório longo (EDL) estão apresentados na tabela 9. Observando a tabela, nota-se que não houve diferença estatisticamente significativa na expressão gênica das enzimas analisadas nesse músculo entre os grupos.

Tabela 9. Análise da expressão gênica de proteínas no músculo EDL.

\begin{tabular}{ccccc}
\hline & ES & ET & DS & DT \\
\hline PFK & $3,74 \pm 1,32$ & $2,08 \pm 1,40$ & $4,78 \pm 1,42$ & $5,65 \pm 1,93$ \\
LDH & $3,20 \pm 1,93$ & $0,68 \pm 1,02$ & $3,74 \pm 1,92$ & $1,08 \pm 1,31$ \\
CS & $2,59 \pm 0,82$ & $1,08 \pm 0,90$ & $2,77 \pm 0,90$ & $2,89 \pm 1,16$
\end{tabular}

Análise da expressão gênica, por RT-PCR (razão gene/RPL 19), das enzimas fosfofrutocinase (PFK), lactato desidrogenase (LDH) e citrato sintase (CS), no músculo EDL dos grupos eutrófico sedentário (ES $n=5$ ), eutrófico treinado (ET $-n=5$ ), desnutrido sedentário ( $D S-n=5$ ), desnutrido treinado (DT $-n=5$ ). Resultados representados em média e erro padrão. $\mathrm{p}<0,05$. 
A tabela 10 descreve os resultados da expressão gênica de enzimas no músculo sóleo. Assim como no músculo EDL, é possível notar que não houve diferença estatisticamente significativa na expressão gênica das enzimas analisadas nesse músculo entre os grupos.

Tabela 10. Análise da expressão gênica de proteínas no músculo sóleo.

\begin{tabular}{ccccc}
\hline & ES & ET & DS & DT \\
\hline PFK & $1,01 \pm 0,25$ & $0,89 \pm 0,29$ & $0,81 \pm 0,33$ & $1,55 \pm 0,38$ \\
LDH & $2,00 \pm 0,34$ & $1,49 \pm 0,43$ & $1,53 \pm 0,48$ & $1,31 \pm 0,55$ \\
CS & $1,40 \pm 0,52$ & $0,86 \pm 0,66$ & $0,42 \pm 0,39$ & $1,46 \pm 0,85$
\end{tabular}

Análise da expressão gênica, por RT-PCR (razão gene/RPL 19), das enzimas fosfofrutocinase (PFK), lactato desidrogenase (LDH) e citrato sintase (CS), no músculo EDL dos grupos eutrófico sedentário (ES $-n=5$ ), eutrófico treinado $(E T-n=5)$, desnutrido sedentário ( $D S-n=5)$, desnutrido treinado (DT $-n=5)$. Resultados representados em média e erro padrão. $\mathrm{p}<0,05$.

A tabela 11 descreve os resultados da expressão gênica de enzimas no músculo gastrocnêmio. Diferentemente às enzimas anteriormente citadas, é possível notar que a enzima carnitina palmitoiltransferase 2 (CPT II), no grupo desnutrido treinado (DT), apresentou-se significativamente maior em relação a todos os outros grupos.

Tabela 11. Análise da expressão gênica de proteínas no músculo gastrocnêmio.

\begin{tabular}{ccccc}
\hline & ES & ET & DS & DT \\
\hline CPT I & $2,63 \pm 0,63$ & $1,24 \pm 0,16$ & $2,11 \pm 0,54$ & $1,91 \pm 0,20$ \\
CPT II & $1,21 \pm 0,38$ & $1,21 \pm 0,21$ & $1,41 \pm 0,17$ & $3,76 \pm 1,29^{*} \dagger \ddagger$
\end{tabular}

Análise da expressão gênica, por RT-PCR (razão gene/RPL 19), das enzimas carnitil palmitoiltransferase 1 e 2 (CPT I e CPT II, respectivamente), no músculo gastrocnêmio dos grupos eutrófico sedentário (ES - n=5), eutrófico treinado $(E T-n=5)$, desnutrido sedentário ( $D S-n=5)$, desnutrido treinado (DT $-n=5$ ). Resultados representados em média e erro padrão. ${ }^{*} \mathrm{p}<0,05$ em relação ao grupo ES. $\dagger \mathrm{p}<0,05$ em relação ao ET. $\ddagger \mathrm{p}<0,05$ em relação ao DS. 


\section{DISCUSSÃO}

A desnutrição protéico-calórica, que acomete cerca de 10,5\% da população brasileira, é uma desordem nutricional caracterizada pela insuficiente ingestão de alimentos e, quando estabelecida de forma crônica, é capaz de produzir respostas adaptativas que, dependendo da gravidade, podem levar à morte (GOLDEN, 2002). De fato, cerca de 20 a 30\% das pessoas desnutridas acabam morrendo devido à carência de ingestão de proteínas e/ou energia (SHOFIELD \& ASHWORTH, 1996; IBGE, 2000).

Uma das repostas mais características da desnutrição, tanto aguda quanto crônica, é a significativa perda de peso corporal (HOLMES et al, 1956; BARAC-NIETO et al, 1978; SPURR et al, 1983). Assim como a literatura há muito já descreve, nosso modelo de desnutrição, com duração de 16 semanas, seguindo o esperado, provocou uma diminuição significativa no peso corporal dos animais. É possível perceber que, com o desenvolvimento do protocolo de desnutrição, os animais que foram submetidos à restrição de alimento apresentaram um significativo menor peso corporal do que os animais controles e, isso permaneceu até a última semana de privação de alimento. Além da redução de peso corporal, a desnutrição também promove um déficit de crescimento acentuado (BARAC-NIETO et al, 1978; SPURR et al, 1983), ou seja, um indivíduo desnutrido, geralmente, apresenta estatura menor do que indivíduos normais, o que também contribui para a redução do peso corporal total.

O treinamento físico também é considerado um clássico indutor de redução do peso corporal, por aumentar o gasto energético do indivíduo, proveniente de fontes armazenadas no corpo, como por exemplo, os depósitos de gordura do tecido adiposo, (ROSS et al, 2000; ROSS et al, 2004). Essa resposta também foi notada em nosso modelo, já que o treinamento foi capaz de promover uma redução de peso corporal do grupo eutrófico treinado (ET) em relação ao eutrófico sedentário (ES). Apesar do peso corporal do ET ser significativamente menor em relação ao ES, a ingestão alimentar não foi menor, demonstrando efetivo efeito do treinamento de endurance. Isso vem de acordo com um balanço energético negativo promovido pelo aumento do gasto energético pelo treinamento físico e uma manutenção da ingestão alimentar. Mas, contrariamente, o grupo desnutrido treinado DT não apresentou uma redução do peso corporal em relação ao desnutrido sedentário (DS), demonstrando que o treinamento associado à desnutrição não é capaz de acentuar, ainda mais, a redução do peso corporal, sugerindo um efeito preservador do treinamento frente à perda de peso promovida pela desnutrição. 
A desnutrição, geralmente, provoca atrofia muscular (GARLICK et al, 1975; WINICK, 1979), redução dos depósitos de gordura (SOARES \& SHETTY, 1991; SHETTY, 1984; FERRO-LUZZI et al, 1997), e também, uma redução no tamanho do fígado (GARLICK 1975; ELIA, 1997). Corroborando os dados descritos na literatura, o peso absoluto dos tecidos muscular e adiposo e do fígado diminuiu nos desnutridos (DS e DT) em relação aos eutróficos (ES e ET), o que pode ser atribuído ao fato da massa corporal apresentada por eles ser cerca de 50\% inferior.

Quando o animal está privado de alimento, além da perda de peso corporal, ocorre um balanço nitrogenado negativo, que pode levar a uma degradação protéica em diversos órgãos, com dimensões diferentes em órgãos distintos (GARLICK et al, 1975). O músculo esquelético pode ser um dos tecidos afetados pela diminuição da ingestão protéico-calórica (GOLDSPINK, 1964; GOLDSPINK, 1965; HENRRIKSSON 1990). Mas, contrariamente, nossos resultados demonstraram que houve uma preservação, ou mesmo, aumento do músculo sóleo, EDL e gastrocnêmio nos desnutridos em relação aos eutróficos. Entre as hipóteses para tal resultado estão o aumento de água intramuscular devido uma diminuição da albumina sérica com a desnutrição (BAERTL et al, 1974), aumento dos depósitos de gordura intramuscular induzido pelo treinamento (BELMONTE et al, 2004), ou ainda, uma supercompensação induzida pelo exercício gerando uma hipertrofia muscular miofibrilar e/ou citoplasmática (DIAZ-HERRERA et al, 2001).

A diminuição de gordura corporal resultante de uma diminuição da ingestão calórica e do exercício físico parece ocorrer de forma diferente em depósitos de tecido adiposo distintos (HANSEN, 2007; OGURI, 2004). O tecido adiposo é um órgão metabólico heterogêneo e pode ser distinguido em diferentes depósitos, que refletem, inerentemente, funcionalidades diferentes (ABATE \& GARG, 1995). O tecido adiposo subcutâneo está localizado mais perifericamente e, representa cerca de $80 \%$ dos estoques deste tecido no corpo (ARNER, 2001). O tecido adiposo visceral, que inclui o retroperitoneal (TARP), o mesentérico (TAME) e o epididimal (TAE), constituem os outros $20 \%$ dos estoques. Esses últimos foram os depósitos de gordura avaliados em nosso estudo e os resultados demonstram que diminuíram significativamente nos animais desnutridos em relação aos eutróficos, resultados corroborados por diversos estudos (SHETTY, 1984; SOARES \& SHETTY 1991; FERRO-LUZZI 1997). Isso ocorreu tanto em termos absolutos quanto relativamente ao peso corporal, demonstrando que nosso modelo de desnutrição é capaz de induzir grande depleção destes estoques. A redução da gordura corporal dos DT em relação aos DS pode ter ocorrido, também, pelo fato 
do exercício físico de endurance induzir diminuição da gordura corporal por um aumento do gasto energético (PHINNEY SD 1988; POEHLMAN ET 1991; DONNELLY JE 1991; WHATLEY 1994), como já descrito anteriormente. Nota-se ainda, que a diminuição da gordura corporal ocorreu de forma distinta nos diferentes depósitos de tecido adiposo, conforme descrito na tabela 2. O peso relativo do tecido adiposo retroperitoneal (TARP) e do epididimal (TAE) dos desnutridos (DS e DT) apresentaou-se menor do que dos eutróficos (ES e ET) e, o tecido adiposo mesentérico (TAME) dos desnutridos (DS e DT) apresentou-se diferente apenas dos ES. Porém, as maiores reduções ocorreram no peso relativo do TARP, em que o desnutrido sedentário (DS) apresentou redução de 69\% e 62,2\% em relação aos eutróficos sedentário e treinado (ES e ET), respectivamente, e, o desnutrido treinado (DT), redução de $76 \%$ e 71,8\% em relação à ES e ET, respectivamente. Este efeito regional diferente nos depósitos de tecido adiposo pode ter sido causado pela diferença na resposta da lipólise induzida pelas catecolaminas e pela sensibilidade desses depósitos às propriedades anti-lipolíticas da insulina circulante (WAJCHENBERG, 2000; McCARTY, 2001), hormônio que regula, por exemplo, a atividade da lipase lipoprotéica de maneira heterogênea nos depósitos de tecido adiposo (BJORNTORP, 1996). Esse estoque de tecido adiposo possui um acesso direto ao fígado através da veia porta, que supre $80 \%$ do sangue que circula pelo fígado, e tem sido descrito como um tecido adiposo com a maior atividade metabólica (ARNER, 2001; LEWIS et al, 2002) e, talvez, por isso, sua redução mais significativa em relação aos outros depósitos.

Além disso, a depleção da gordura corporal nos animais desnutridos em relação aos eutróficos, além de ser representada pela diminuição nos depósitos de tecido adiposo (TARP, TAME e TAE), também pode ser percebida pela redução do conteúdo de gordura na carcaça e pelo percentual de gordura corporal desses animais, em que o grupo desnutrido sedentário (DS) apresentou significativa diminuição, de 63,1\%, no conteúdo de gordura corporal total em relação ao eutrófico sedentário (ES), assim como, o desnutrido treinado (DT) apresentou uma redução de 81\% e 84,46\% em relação ao ES e ET, respectivamente. O percentual de gordura corporal foi significativamente reduzido no DS em relação ao ES (-41,7\%) e, também no DT, em relação ao ES (-63,8\%) e ET (-71,3\%). Essa significativa redução, dentre os fatores já anteriormente citados, em repouso também pode estar associada ao fornecimento de ácidos graxos para outros tecidos e, mais especificamente, para o fígado, para a formação de corpos cetônicos. 
Durante a desnutrição, uma vez que, a ingestão de alimentos ocorre em momentos aleatórios, podendo o indivíduo passar por períodos de jejum bastante prolongados, geralmente ocorre uma redução da glicemia e um, conseqüente, aumento da captação dos triglicerídeos no tecido adiposo, que transformados em ácidos graxos, serão precursores dos corpos cetônicos no fígado (SALWAY, 2004b). A concentração de corpos cetônicos no sangue de indivíduos saudáveis e alimentados é bastante baixa, mas pode aumentar para 2 a 3 mM após 3 dias de jejum, e para 7 a 8 mM após 3 semanas sem a ingestão de alimentos (TURCOTTE et al, 1995). A taxa com que os corpos cetônicos são produzidos é aumentada para serem usados por tecidos como o músculo esquelético, músculo cardíaco, e principalmente, pelo tecido nervoso, para a geração de ATP (TURCOTTE et al, 1995). Conseqüentemente, a utilização da glicose como substrato energético pelo sistema nervoso será diminuída gradativamente com a prolongação do tempo de desnutrição, de $80 \mathrm{~g} /$ dia para cerca de 35/g/dia (EMERY, 2005), apresentando assim, uma importante vantagem ao desnutrido, já que menos glicose precisa ser obtida pela gliconeogênese a partir de amino ácidos do músculo esquelético, permitindo uma maior preservação desse tecido. Além dessa importante adaptação ao estresse da desnutrição, a cetose também promove um importante efeito poupador de glicose, que por sua vez, pode produzir um efeito poupador das reservas de glicogênio (SALWAY, 2004b).

O fígado e o músculo são os principais depósitos de glicogênio, sendo importantes reservas de energia para a geração de ATP (SALWAY, 2004a). A disponibilidade de glicogênio muscular é fundamental para a realização de exercícios físicos prolongados, fato demonstrado pela observação de que a fadiga é, freqüentemente, associada com a depleção desses estoques (COYLE et al, 1983; COGGAN \& COYLE, 1987; HARGREAVES, 1995). A utilização do glicogênio muscular no exercício físico ocorre durante os primeiros minutos, sendo que a taxa de utilização e sua continuidade está exponencialmente relacionada com a intensidade do exercício (GOLLNICK et al, 1974; HARGREAVES, 1995), ou seja, quanto maior a intensidade, maior a utilização do glicogênio muscular para a ressíntese de ATP e vice-versa. Com a prolongação do tempo de exercício, a taxa de utilização de glicogênio muscular diminui como resultado da diminuição da disponibilidade do mesmo e/ou do aumento da disponibilidade de substratos alternativos como os ácidos graxos (HARGREAVES, 1995). A proporção dos substratos utilizados durante o exercício físico também depende da intensidade e da duração do exercício, do nível de treinamento e do status nutricional do indivíduo, como dietas ricas em carboidratos ou em gorduras, ou, ao contrário, 
a inanição advinda da desnutrição. Por exemplo, aumentando a disponibilidade de lipídios durante o exercício, ocorre um aumento da oxidação dos ácidos graxos e uma redução da oxidação de carboidratos (DICK et al, 1993; HARGREAVES et al, 1991;). COYLE \& HODGKINSON (1999) descrevem que uma dieta rica em lípides induz adaptações no músculo esquelético que promovem a oxidação lipídica e poupa o glicogênio durante o exercício quando a concentração de glicogênio muscular pré-exercício é normal. Após um período de adaptação com uma dieta rica em lípides com uma ingestão aumentada de carboidratos, observa-se um aumento dos estoques de glicogênio pré-exercício sem proporcionalmente aumentar a taxa de utilização desse durante o exercício. Os autores descrevem ainda que, com isso, é esperado uma melhor capacidade em desempenhar exercícios de endurance. Isso foi demonstrado, por exemplo em um experimento em que após 3 semanas ingerindo uma dieta pobre em carboidratos, seguida de 3 dias ingerindo uma dieta rica em carboidratos, os níveis de glicogênio muscular e hepático de ratos se tornou maior do que ratos alimentados com uma dieta constante com quantidade elevada de carboidratos (LAPACHET et al, 1996; CONLEE et al, 1990; SAITOH et al ,1996). Além disso, a concentração de triglicerídio intramuscular se apresentou maior do que os animais alimentados com dieta constante rica em carboidratos (SAITOH et al ,1996). Conseqüentemente, o desempenho no tempo até a exaustão foi melhor nos animais com dieta rica em lipídios seguida de dieta rica em carboidratos do que os animais com dieta constante rica em carboidratos (LAPACHET et al, 1996; CONLEE et al, 1990). Paralelamente, podemos dizer que nosso modelo de desnutrição e exercício apresenta resultados semelhantes, porém com uma manipulação antagônica, já que os animais desnutridos passam cerca de 18 a 30 horas sem ingerir alimentos e, portanto, apresentam as adaptações inerentes a isso, como descrito anteriormente, com o aumento dos ácidos graxos para formação de corpos cetônicos e, conseqüente, redução da glicogenólise e preservação dos estoques de glicogênio. E, provavelmente, os desnutridos que se exercitam, da mesma forma, se adaptaram a poupar o carboidrato para a formação de glicogênio e a oxidar mais os lipídios quando ingerem o alimento. Isso pode ser percebido com os resultados obtidos em nosso estudo que demonstraram que a concentração de glicogênio muscular foi maior nos animais desnutridos treinados (DT) em relação a todos os outros grupos (ES, ET e DS).

A formação do glicogênio muscular depende da concentração de glicose sangüínea e de sua captação para o interior desse tecido. Esse processo, em repouso, é facilitado pela insulina, hormônio regulador da captação de glicose para os tecidos (HARGREAVES, 1995), 
mas durante o exercício, sabe-se que a contração muscular por si só estimula o transporte de glicose para dentro desse tecido (CONSTABLE et al, 1988), apesar de estudos também terem demonstrado que existe um efeito aditivo da contração muscular e da insulina, significando que a insulina e o exercício ativam o transporte de glicose por mecanismos diferentes (NESHER et al, 1985; PLOUG et al, 1987; WALLBERG-HENRIKSSON et al, 1988; PLOUG et al, 1992). Já em 1972, BJORNTORP e colaboradores (1972), foram os primeiros a sugerir que o treinamento físico podia aumentar a sensibilidade do músculo esquelético à insulina, o que foi confirmado por estudos subseqüentes que demonstraram que indivíduos treinados necessitavam de uma menor concentração de insulina no plasma em resposta a uma carga de glicose do que indivíduos sedentários e, a despeito da menor resposta à insulina, apresentaram uma maior tolerância à glicose (JOHANSEN \& MUNCH, 1979; LOHMAN et al, 1978; LeBLANC et al, 1979; LeBLANC et al, 1981; SEALS et al, 1984). Os resultados obtidos em nosso estudo demonstraram que a glicemia dos animais desnutridos sedentários (DS) apresentou-se reduzida em relação a todos os outros grupos (ES, ET e DT), fato já relatado na literatura, uma vez que, na desnutrição a ingestão de alimentos ocorre em momentos aleatórios, podendo o indivíduo passar por longos períodos de jejum, com então, uma redução da glicemia (GOLDSTEIN \& CURNOW, 1978; TORUN \& CHEW, 1999; SALWAY, 2004b). Apesar da glicemia reduzida, o grupo desnutrido sedentário apresentou insulinemia igual a todos os outros grupos que, por sua vez, não apresentaram diferenças entre si. Porém, a insulinemia do grupo desnutrido treinado (DT) demonstrou uma tendência em estar reduzida em relação a todos os outros grupos e, o índice insulina/glicose desse grupo apresentou significativa redução em relação aos ES, ET e DS. Com esse resultado, parece que a associação dos dois protocolos, a desnutrição e o treinamento, não só reverteu a glicemia aos valores normais, como aumentou a sensibilidade à insulina, já que menos insulina é necessária para a captação da mesma quantidade de glicose, proporcionado, provavelmente, em decorrência do treinamento físico, como já descrito anteriormente. Isso também pode sugerir que os animais desnutridos treinados (DT) podem estar captando melhor a glicose no músculo esquelético e, isso também pode estar levando ao maior acúmulo de glicogênio como também demonstrado somente no grupo DT.

Durante o exercício físico de endurance, as células musculares são abastecidas por substratos armazenados em seu interior como o glicogênio e o triacilglicerol e, circulatórios como a glicose e os ácidos graxos. As mitocôndrias, por sua vez, consomem mais rapidamente os substratos que estão armazenados no próprio músculo do que os circulatórios 
(HOPPELER \& BILLETER, 1991). A concentração do glicogênio muscular possui uma relação direta com a intensidade do exercício e, desta forma, um indivíduo com maior estoque de glicogênio é capaz de realizar exercício em intensidades maiores (BERGSTROM et al, 1967). Além disso, durante o exercício de endurance, quanto maior a capacidade do indivíduo em captar, transportar e consumir o oxigênio, ou seja, quanto melhor sua capacidade funcional cardiorrespiratória medida através do $\mathrm{VO}_{2 \text { máx }}$ melhor será seu desempenho (BASSET \& HOWLEY, 2000). Notamos que os animais do grupo desnutrido treinado (DT), além de apresentarem uma maior concentração de glicogênio muscular, apresentaram também um melhor $\mathrm{VO}_{2 \text { máx }}$ do que os eutrófico sedentário e treinado (ES e ET) e os desnutridos sedentários. O consumo máximo de oxigênio $\left(\mathrm{VO}_{2 \text { máx }}\right)$ desse grupo, após 10 semanas de treinamento, foi significativamente maior do que seu grupo controle que também treinou, o eutrófico treinado (ET).

Diferentemente, em um estudo realizado por BARAC-NIETO e colaboradores (1978) com 49 indivíduos adultos desnutridos, demonstrou que o $\mathrm{VO}_{2 m a ́ x}$ desses indivíduos era menor comparado a indivíduos normais, porém, foi demonstrado posteriormente pelo mesmo grupo que essa redução do $\mathrm{VO}_{2 \text { máx }}$ estava relacionada à reduzida massa muscular apresentada pelos desnutridos, o que não ocorreu com os desnutridos treinados em nosso modelo experimental e, talvez, por isso o maior $\mathrm{VO}_{2 \text { máx }}$ apresentado por eles. Em outro estudo do grupo, foi demonstrado que com a renutrição com uma dieta rica em proteínas durante 45 dias, houve um aumento da massa muscular e do $\mathrm{VO}_{2 \text { máx }}$ em indivíduos desnutridos, demonstrando a importância desse componente para um melhor consumo de oxigênio (BARAC-NIETO et al, 1980). Mais adiante, SPURR e colaboradores (1983), publicaram que crianças de 6 a 16 anos de idade desnutridas, apresentavam um menor $\mathrm{VO}_{2 \text { máx }}$ do que crianças consideradas normais. Por outro lado, em outro estudo publicado posteriormente por SPURR e colaboradores (1984) com crianças, demonstrou que as consideradas desnutridas apresentaram um melhor consumo de oxigênio em uma carga submáxima de exercício do que crianças normais. Parece então que, a massa muscular não diminuída do grupo desnutrido

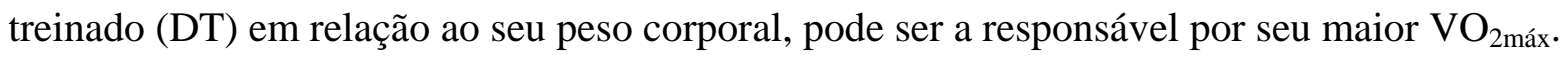

Além de um maior $\mathrm{VO}_{2 \text { máx }}$, os animais DT apresentaram, curiosamente, um melhor desempenho de corrida na esteira do que todos os outros grupos. Isso ocorreu tanto em relação ao tempo até a exaustão, quanto à velocidade atingida no momento da fadiga. O grupo eutrófico treinado (ET) também apresentou o mesmo resultado em relação aos grupos sedentários (ES e DS), demonstrando um efeito positivo do treinamento de endurance de 10 
semanas aplicado. O grupo desnutrido treinado (DT) demorou 36,36\% mais tempo para entrar em exaustão do que o eutrófico treinado (ET), ou seja, 13,4 minutos a mais para chegar à fadiga. Afora, demorou 69,8 e 72,11\% mais tempo até a exaustão do que os grupos eutrófico e desnutrido sedentários (ES e DS), respectivamente. Também atingiu 20,4\% maior velocidade de corrida no momento da exaustão do que o grupo ET, mais de $10 \mathrm{~m} / \mathrm{min}$ mais veloz. Além disso, também atingiu 53,8 e 53,3\% maior velocidade do que os grupos ES e DS, respectivamente. De forma oposta, o estudo de BARAC-NIETO e colaboradores (1978) realizado com humanos, demonstrou que a capacidade de endurance, ou seja, a resistência à exaustão de desnutridos, a $80 \%$ do $\mathrm{VO}_{2 \text { máx }}$, não foi diferente a indivíduos normais. Porém, diferentemente do nosso modelo, os indivíduos desnutridos eram sedentários e, portanto, assemelha-se aos resultados encontrados entre os grupos eutrófico sedentário (ES) e desnutrido sedentário (DS), que após 10 semanas sem treinamento, também não apresentaram diferenças em relação à resistência a exaustão. Não foram encontrados estudos em que desnutridos foram submetidos a um período de treinamento e depois avaliados quanto ao desempenho.

Sabidamente um bom desempenho em exercícios de endurance é dependente de variáveis como a composição corporal, o conteúdo de glicogênio muscular, o $\mathrm{VO}_{2 \text { máx }}$ e também depende da capacidade oxidativa do músculo esquelético de ressintetizar ATP para a continuação do exercício. Como já discutido anteriormente, sabe-se que além do glicogênio muscular e da glicose sangüínea, os ácidos graxos também são importantes substratos energéticos para a produção de ATP durante a realização de exercícios de endurance. Desta forma, as principais vias metabólicas de geração de ATP durante o exercício prolongado de intensidade moderada são a glicólise aeróbia no ciclo de Krebs e na cadeia de transporte de elétrons, e a $\beta$-oxidação dos ácidos graxos. Essas reações que ocorrem para a geração do ATP são catalisadas por enzimas, dentre as quais avaliamos a expressão gênica de algumas delas. Além disso, sabe-se que tanto a desnutrição quanto o treinamento físico são capazes de promover uma série de adaptações fisiológicas e bioquímicas no músculo esquelético.

O treinamento de endurance é capaz de promover um upregulation, ou seja, uma adaptação positiva na atividde de diversas enzimas metabólicas e essa adaptação bioquímica está associada com a melhor capacidade oxidativa do músculo esquelético (SPINA et al, 1996; CARTER et al, 2001). Já a desnutrição, com um menor consenso, parece promover uma redução da atividade de enzimas metabólicas, principalmente, relacionadas ao 
metabolismo glicolítico (LAYMAN, et al, 1981; RUSSEL et al, 1984a; BISSONNETTE et al, 1997).

O início do processo da glicólise é determinado por uma enzima chave, a fosfofrutocinase (PFK), que é regulada, principalmente, pelo estado energético da célula muscular com a quantidade de substrato que lhe é fornecida (STANLEY \& CONNETT, 1991). Conforme descrito por RUSSEL e colaboradores (1984a), a atividade da PFK demonstrou-se reduzida após um período de restrição calórica. No mesmo sentido, BISSONNETTE e colaboradores (1997) demonstraram haver um fluxo glicolítico diminuído no músculo sóleo de desnutridos, sugerindo uma redução da atividade dessa via. Diferentemente, com a realização de exercício físico de alta intensidade, por ser um exercício que exige um maior fornecimento de energia pela via glicolítica, ocorre um aumento da atividade dessa enzima no músculo esquelético (ENRIKSSON et al, 1973; GOLLNICK et al, 1974). Porém, o mesmo não foi percebido com o treinamento físico de endurance (REITMAN \& HENRIKSSON, 1976), que requer, predominantemente, a ressíntese de ATP a partir de vias oxidativas. Esse padrão foi percebido também em nosso modelo, já que o grupo eutrófico que realizou o treinamento de endurance (ET) não apresentou diferença na expressão gênica da PFK em relação ao seu controle sedentário (ES). Da mesma forma, o grupo desnutrido que treinou (DT) também não apresentou diferença em relação ao seu controle sedentário (DS). Além disso, a desnutrição per se não foi capaz de diminuir a expressão gênica dessa enzima em nosso modelo, diferentemente dos resultados encontrados por RUSSEL et al (1984a) e BIOSSONETTE et al (1997), já que o grupo desnutrido sedentário (DS) não apresentou diferença em relação ao eutrófico sedentário (ES). Porém, a não alteração na expressão gênica dessa enzima com a desnutrição não quer dizer, necessariamente, que a atividade dela não possa estar diminuída, como descreveram os últimos autores citados. Mas, se de fato essa diminuição da atividade ocorreu, isso não se refletiu em uma maior expressão dessa proteína no músculo sóleo e EDL dos animais em nosso modelo experimental.

Ainda com relação à glicólise, no final do seu processo, ocorre a formação de piruvato que pode ser metabolizado no citoplasma para se transformar em acetil-CoA, ou ainda, ser convertido em lactato com a oxidação de NADH em NAD em uma reação catalizada pela lactato desidrogenase (LDH) (HARGRAVES, 1995). Em outro estudo realizado por RUSSEL e colaboradores (1984b), foi demonstrado que a desnutrição provocou uma elevação da concentração de piruvato e de lactato, o que poderia então, aumentar a atividade da enzima 
lactato desidrogenase (LDH) que cataliza a conversão do piruvato em lactato pela oxidação de NADH em NAD. E, da mesma forma que a PFK, o exercício de alta intensidade provoca um aumento da LDH no músculo esquelético (HEIGENHAUSER \& PAROLIN, 1999), mas diferentemente, o treinamento de endurance também é capaz de aumentar sua atividade (SPRIETT et al, 2000). Diferentemente, nossos resultados demonstraram não haver modificação na expressão gênica da LDH com a desnutrição, com o exercício físico, nem com a associação dos dois protocolos. Mas, isso não significa que a atividade dessa enzima não possa ter sido alterada.

Se ao invés do piruvato ser convertido em lactato, ele for transportado para o interior da mitocôndria e, convertido em acetato unindo-se à coenzima-A para formar acetil-CoA, ele pode se combinar ao oxaloacetato formando citrato que, será então catalizada pela citrato sintase (CS) no ciclo de Krebs. Assim, o piruvato pode então, ser utilizado pelo metabolismo oxidativo, tendo a atividade da CS como ponto-chave da via HEIGENHAUSER \& PAROLIN, 1999; SPRIET \& HEIGENHAUSER, 2002). Um estudo realizado por MATECKI e colaboradores (2002) demonstrou uma significativa redução da atividade da enzima CS em ratos Wistar, desnutridos por 5 semanas com $40 \%$ da dieta de animais eutróficos. Além disso, um outro estudo realizado por LAYMAN e colaboradores (1981) demonstrou que desnutridos apresentavam uma redução da atividade da succinato desidrogenase (SDH) no músculo esquelético, outra enzima chave do metabolismo oxidativo no ciclo de Krebs. Contrariamente, o exercício físico de endurance aumenta a atividade dessas enzimas. Há mais de 30 anos atrás, HOLLOSZY e colaboradores (1970) foram os primeiros a relatar que o treinamento de endurance aumenta a atividade dessas enzimas no músculo esquelético. Isso tornou-se consenso, posteriormente, com a publicação de inúmeros trabalhos demonstrando os efeitos do treinamento de endurance sobre a capacidade oxidativa e características metabólicas do músculo esquelético (HOLLOSZY \& BOOTH, 1976; SANCHEZ et al, 1983; WILLIAMS et al, 1986; SPINA et al, 1996; NATIO et al , 2001). Apesar da tendência da expressão gênica da CS diminuir no músculo sóleo nos desnutridos sedentários (DS) em relação aos eutróficos sedentários (ES), a desnutrição não foi capaz de provocar alterações na expressão gênica dessa enzima. Da mesma forma, o treinamento de endurance não alterou a expressão dessa enzima, demonstrado pela ausência de diferença entre os grupos treinados (ET e DT) em relação aos sedentários (ES e DS), assim como, a associação dos protocolos de desnutrição e treinamento de endurance também não provocou alterações.

Os ácidos graxos também são importantes substratos para a produção de ATP durante a realização de exercícios de endurance. Um aumento da oxidação de ácidos graxos é 
facilitado pelo aumento da capacidade de captá-los para a célula muscular (IBRAHIMI et al, 1999) e transportá-los para a mitocôndria para serem oxidados (HELGE \& KIENS, 1997). Esse transporte para o interior da mitocôndria é regulado pelo complexo enzimático carnitina palmitoiltransferase I e II (CPT I e II). O exercício físico de endurance é capaz de promover um aumento da atividade e da expressão gênica da enzima CPT I no músculo esquelético (BERTHON et al, 1998; TUNSTALL et al, 2002). TUNSTALL e colaboradores (2002) ainda descrevem que uma única sessão de exercício com 1 hora de duração não foi capaz de aumentar a atividade ou a expressão dessa enzima, mas após a realização de várias sessões, ou seja, com o treinamento, houve um aumento significativo. Da mesma forma, foi demonstrado por de BARROS REIS e colaboradores (2007) que ocorre um aumento da atividade da CPT I nas ilhotas pancreáticas com a desnutrição, mas não um aumento da expressão gênica dessa enzima. RYU e colaboradores (2005) demonstraram que um período de 48 horas em jejum, provocou um aumento significativo da expressão gênica da CPT I no fígado de ratos. Um outro estudo conduzido por HOLNESS e colaboradores (1998) mostrou que a desnutrição materna não afetou a atividade da CPT I no músculo cardíaco dos fetos. Não foram encontrados estudos avaliando essa enzima em músculo esquelético de desnutridos. Nosso estudo, porém, avaliou a expressão gênica da CPT I e da CPT II no músculo gastrocnêmio e, observou que após o período de desnutrição, a CPT I não se modificou, mas a CPT II no grupo desnutrido treinado (DT), aumentou sua expressão gênica em relação a todos os outros grupos. Isso demonstra um efeito da desnutrição associada ao treinamento de endurance nos animais avaliados, enquanto somente o treinamento de endurance, contrariamente à literatura, não apresentou elevação da expressão dessa enzima. Esses resultados sugerem que a síntese aumentada da CPT II pode representar uma resposta adaptativa que leva o animal desnutrido treinado a possuir uma melhor capacidade oxidativa de lipídios durante a realização do exercício de endurance.

Assim, parece que quando um rato desnutrido é submetido ao treinamento de endurance, ele é capaz de apresentar uma melhor resposta adaptativa, demonstrando um melhor desempenho físico, demonstrado por uma maior velocidade e maior resistência para chegar à fadiga, um maior consumo máximo de oxigênio, maior concentração de glicogênio muscular, por uma provável melhor captação de glicose pelo músculo, e por uma composição corporal mais favorável, ou seja, com menos gordura corporal e uma massa muscular mantida em relação aos seus controles. Por fim, a habilidade de um animal se locomover com uma menor massa corporal e desempenhar tarefas consumindo menos oxigênio do que um animal 
maior, mostra-se claramente vantajoso se bem adaptado, como parece ter ocorrido com os animais desnutridos treinados (DT). 


\section{CONCLUSÃO}

Tendo em vista os resultados obtidos nesse estudo, podemos concluir que o treinamento de endurance em ratos submetidos à desnutrição crônica promoveu uma acentuada redução do peso e da adiposidade corporal; um aumento da massa muscular relativa ao peso corporal; um restabelecimento da glicemia aos valores normais; uma melhor relação da concentração insulina/glicose, sugerindo uma sensibilidade à insulina aumentada; um aumento dos estoques de glicogênio muscular; um maior consumo máximo de oxigênio; e um aumento da expressão gênica da enzima CPT II.

Todos esses resultados contribuíram para um, curioso e inesperado, melhor desempenho de endurance, e podem explicar, uma maior velocidade de corrida e uma maior resistência à fadiga apresentada pelos animais desnutridos submetidos ao treinamento aeróbio. Em suma, os animais desnutridos treinados apresentaram uma melhor resposta ao treinamento e uma maior capacidade de endurance. 


\section{REFERÊNCIAS BIBLIOGRÁFICAS}

ABATE, N.; GARG, A. Heterogeneity in adipose tissue metabolism: causes, implications and management of regional adiposity. Prog. Lipid Res., v. 34, p. 53-70, 1995.

AKUYAM, S.A. A review of some metabolic changes in protein-energy malnutrition. Niger Postgrad. Med. J., v.14, p. 155-162, 2007.

ARNER, P. Regional differences in protein production by human adipose tissue. Biochem. Soc. Trans., v. 29, p.72-75, 2001.

ARONE, L.J.; MACKINTOSH, R.; ROSENBAUM, M.; LEIBEL, R.L.; HIRSCH, J. Autonomic nervous system activity in weight gain and weight loss. Am. J. Physiol., v. 269, p. R222-225, 1995.

ASTRAND, P.-O. Endurance sports. In: SHEPARD, R.J.; ASTRAND, P.-O. (Ed.). Endurance in sport. $2^{\mathrm{a}}$ ed. Oxford: Blacwell Science, 2000.

BAERTL, J.M.; PLACKO, R.P.; GRAHAM, C.G. Serum proteins and plasma free amino acids of energy deficiency. Eur. J. Clin. Nutr., v. 44, p. 55-64, 1990.

BARAC-NIETO, M.; SPURR, G.B.; DAHNERS, H.W.; MAKSOUD, M.G. Aerobic work capacity and endurance during nutritional repletion of severely undernourished men. Am. J. Clin. Nutr., v. 33, p. 2268-2275, 1980.

BARAC-NIETO, M.; SPURR, G.B.; LOTERO, H.; MAKSUD, M.G. Body composition in chronic undernutrition. Am. J. Clin. Nutr., v. 31, p. 23-40, 1978.

BARAC-NIETO, M.; SPURR, G.B.; MAKSUD, M.G.; LOTERO, H. Aerobic work capacity in chronically undernourished adult males. J. Appl. Physiol., v. 44, p. 209-215, 1978.

BARLETT, K.; EATON, S. Mitochondrial beta-oxidation. Eur. J. Biochem., v. 271, p. 462469, 2004.

BASSET, D.R.Jr.; HOWLEY, E.T. Limiting factors for maximum oxygen uptake and determinants of endurance performance. Med. Sci. Sports Exerc., v. 32, p. 70-84, 2000.

BASSIT, R.A.; SAWADA, L.A.; BACURAU, R.F.; NAVARRO, F.; MARTINS, E.Jr.; SANTOS, R.V.; CAPERUTO, E.C.; ROGERI, P.; COSTA ROSA, L.F. Branched-chain amino-acid supplementation and the immune response of long-distance athletes. Nutrition, v. 18, p. 376-379.

BELMONTE, M.A.; AOKI, M.S.; TAVARES, F.L.; SEELAENDER, M.C.L. Rat myocellular and perimysial intramuscular triacylglycerol: a histological approach. Med. Sci. Sports Exerc., v. 36, p. 60-67, 2004.

BERGER, M.; HAGG, S.; GOODMAN, M.; RUDERMAN, N.B. Glucose metabolism in perfused skeletal muscle: effects of starvation, diabetes, fatty acids, acetoacetate, insulin and exercise on glucose uptake and deposition. Biochem. J., v. 158, p. 191-202, 1976. 
BERGSTROM, J.; HERMANSEN, L.; HULTMAN, F.; SALTIN, B. Diet, muscle glycogen and physical performance. Acta Physiol. Scand., v. 71, p. 140-150, 1967.

BERTHON, P.M.; HOWLETT, R.A.; HEIGENHAUSER, G.J.F.; SPRIET, L.L. Human skeletal muscle carnitine palmitoyltransferase I activity in isolated intact mitochondria. $\mathbf{J}$. Appl. Physiol., v. 85, p. 148-153, 1998.

BISSONNETTE, D.J.; MADAPALLIMATAM, A.; JEEJEEBHOY, K.N. Effect of hypoenergetic feeding and high-carbohydrate refeeding on muscle titanic, relaxation rate, and fatigue in slow- and fast-twitch muscles in rats. Am. J. Clin. Nutr., v. 66, p. 293-303, 1997.

BJORNTORP, P.; FAHLEN, M.; GRIMB,Y.G.; GUSTAFSON, A.; HOLM, J.; RENSTRÖM, P.; SCHERSTÉN, T. Carbohydrate and lipid metabolism in middleaged physically well trained men. Metabolism, v. 21, p. 1037-1044, 1972.

BLACK, R.; MORRIS, S.; BRYCE, J. Where and why are 10 million children dying every year? Lancet, v. 361, p. 2226-2234, 2003.

BONNEFONT, J.P.; DJOUADI, F.; PRIP-BUUS, C.; GOBINS, S.; MINNICH, A.; BASTIN, J. Carnitine palmitoyltransferases 1 and 2: biochemical, molecular and medical aspects. Mol. Aspects Med., v. 25, p. 495-520, 2004.

CARBOnNel, F. [Metabolic adaptation to malnutrition]. Ann. Med. Interne (Paris), v. 151, p.644-651, 2000.

CARTER, S.L.; RENNIE, C.D.; HAMILTON, S.J.; TARNOPOLSKY, M.A. Changes in skeletal muscle in males and females following endurance training. Can. J. Physiol. Pharmacol., v.79, p. 382-392, 2001.

CHANDRA, R.K. Nutrition and immune responses. Can. J. Physiol. Pharmacol., v. 61, p. 290-294, 1983.

COETZER, P.; NOAKES, T.D.; SANDERS, B.; LAMBERT, M.I.; BOSCH, A.N.; WIGGINS, T.; DENNIS, S.C. Superior fatigue resistance of elite black South African distance runners. J. Appl. Physiol., v. 75, p. 1822-1827, 1993.

COGGAN, A.R.; COYLE, E.F. Reserval of fatigue during prolonged exercise by carbohydrate infusion or ingestion. J. Appl. Physiol., v. 63, p. 2388-2395, 1987.

COGGAN, R.A.; WILLIAMS, B.D. Metabolic adaptations to endurance training: substrate metabolism during exercise. In: HARGREAVES, M. (Ed.). Exercise Metabolism. $1^{\text {a }}$ ed. United States of America: Human Kinetics Publishers, 1995.

CONLEE, R.K.; HAMMER, R.L.; WINDER, W.W.; BRACKEN, M.L.; NELSON, A.G.; BARNETT, D.W. Glycogen repletion and exercise endurance in rats adapted to a high fat diet. Metabolism, v. 39, p. 289-294, 1990.

CONLEY, D.L.; KRAHENBUHL, G.S. Running economy and distance running performance of highly trained athletes. Med. Sci. Sports Exerc., v. 12, p. 357-360, 1980. 
CONSTABLE, S.H.; FAVIER, R.J.; CARTEE, G.D.; YOUNG, D.A.; HOLLOSZY, J.O. Muscle glucose transport: interactions of in vitro contractions, insulin and exercise. $\mathbf{J}$. Appl. Physiol., v. 64, p. 2329-2332, 1988.

CONTABLE, S.H.; FAVIER, R.J.; HOLOSZY, J.O. Exercise and glycogen depletion: effects on the stability to activate muscle phosphorylase. J. Appl. Physiol., v. 60, p. 1518-1523, 1986.

COSTILL, D.L. Carbohydrate for exercise: dietary demand for optimal performance. Int. J. Sports Med., v. 9, p. 1-18, 1988.

COSTILL, D.L.; SPARKS, K.; GREGOR, R.; TURNER, C. Muscle glycogen utilization during exhaustive running. J. Appl. Physiol., v. 31, p. 353-356, 1971.

COYLE, E.F.; COGGAN, A.R.; HEMMERT, M.K.; IVY, J.L. Muscle glycogen utilization during prolonged strenuous exercise when fed carbohydrate. J. Appl. Physiol., v.61, p. 165-172, 1986.

COYLE, E.F.; HAGBERG, J.M.; HURLEY, B.F.; MARTIN, W.H.; EHSANI, A.A.; HOLOSZY, J.O. Carbohydrate feeding during prolonged strenuous exercise can delay fatigue. J. Appl. Physiol., v. 55, p. 230-235, 1983.

CUMMING, D.C.; BRUNSTING, L.A.III; STRICH, G.; RIES, A.L.; REBAR, R.W. Reproductive hormone increases in response to acute exercise in men. Med. Sci. Sports Exerc., v. 18, p. 369-373, 1986.

CUMMING, D.C.; WALL, S.R.; QUINNEY, H.A.; BELCASTO, A.N. Decrease in serum testosterone levels with maximal intensity swimming exercise in trained male and female swimmers. Endocr. Res., v. 13, p. 31-41, 1987.

CUMMING, D.C.; WHEELER, G.D.; McCOLL, E.M. The effects of exercise on reproductive function in men. Sports Med., v. 7, p. 1-17, 1989.

CUNHA, W.D.S.; FRIEDLER, G.; VAISBERG, M.; EGAMI, M.I.; COSTA ROSA, L.F.B.P. Immunosuppression in undernourished rats: the effect of glutamine supplementation. Clin. Nutr., v. 22, p. 453-457, 2003.

de BARROS REIS, M.A.; ARANTES, V.C.; CUNHA, D.A.; LATORRACA, M.Q.; TOYAMA, M.H.; CARNEIRO, E.M.; BOSCHERO, A.C. Increased L-CPT-1 activity and altered gene expression in pancreatic islets of malnourished adult rats: a possible relationship between elevated free fatty acid levels and impaired insulin secretion. $\mathbf{J}$. Nutr. Biochem., v. 23, em processo de publicação, 2007.

DENADAI, B.S. Consumo máximo de oxigênio: fatores determinantes e limitantes. Rev. Brás. Ativ. Fís. Saúde, v. 1, p. 85-94, 1995.

DUMAS, J.F.; ROUSSEL, D.; SIMARD, G.; DOUAY, O.; FOUSSARD, F.; MALTHIERY, Y.; RITZ, P. Food restriction affects energy metabolism in rat liver mitochondria. Biochim. Biophys. Acta, v. 1670, p. 126-131, 2004. 
DYCK, D.J.; PUTMAN, C.T.; HEIGENHAUSER, G.J.F.; HULTMAN, E.; SPRIET, L.L. Regulation of fat-carbohydrate interaction in skeletal muscle during intense exercise aerobic cycling. Am. J. Physiol., v. 265, p. E852-E859, 1993.

ELIA, M. Tissue distribution and energetics in weight loss and undernutrition. In: KINNEY, J.M., TUCKER, H.N. (Ed.). Physiology, stress and malnutrition: functional correlates, nutritional intervention. Philadelphia: Lippincott-Raven Publishers. 1997. p. 383-411.

EMERY, P.W. Metabolic changes in malnutrition. Eye, v. 19, p.1029-1034, 2005.

ERIKSSON, B.O.; GOLLNICK, P.D.; SALTIN, B. Muscle metabolism and enzyme activities after training in boys 11-13 years old. Acta Physiol. Scand., v. 87, p. 485-497,1973.

ERNSBERGER, P.; NELSON, D.O. Effects of fasting and refeeding on blood pressure are determined by nutritional state, not by body weight change. Am. J. Hypertens. v. 01, p. 153S-157S, 1988.

FERRO-LUZZI, A.; PETRACHI, C.; KURIYAN, R.; KURPAD, A.V. Basal metabolism of eight stable chronically undernourished men and women, lack of metabolic adaptation and ethnic differences. Am. J. Clin. Nutr., v. 66, p. 1086-1093, 1997.

FUGE, K.W.; CREWS III, E.L.; PATTENGALE, P.K.; HOLLOZSY, J.O.; SHANK, R.E. Effects of protein deficiency on certain adaptative responses to exercise. Am. J. Physiol. v. 215, p. 660-663, 1968.

GARLICK, P.J.; MILLWARD, D.J.; JAMES, W.P.T.; WATERLOW, J.C. The effect of protein deprivation and starvation on the rate of protein synthesis in tissues of the rat. Biochim. Biophys. Acta, v. 414, p. 71-84, 1975.

GARLICK, P.J.; MILLWARD, D.J.; JAMES, W.P.T.; WATERLOW, J.C. The effect of protein deprivation and starvation on the rate of protein synthesis in tissue of the rat. Biochim. Biophys. Acta, v. 414, p. 71-84, 1975.

GERTZ, E.W.; WISNESKI, J.A.; STANLEY, W.C.; NEESE, R.A. Myocardial substrate utilization during exercise in humans: dual carbon-labeled carbohydrate isotope experiments. J. Clin. Invest., v. 82, p.2017-2025, 1988.

GINER, M.; LAVIANO, A.; MEGUID, M.M.; GLEASON, J.R. In 1995 a correlation between malnutrition and poor outcome in critically ill patients still exists. Nutrition, v. 12, p. 23, 1996.

GOLDEN, M.H.N. The development of concepts of malnutrition. J. Nutr., v. 132, p. 2117S2122S, 2002.

GOLDEN, M.H.N.; GOLDEN, B.E. Severe malnutrition. In: GARROW, J.S.; JAMES, W.P.T.; RALPH, A. (Ed.). Human Nutrition and Dietetics. 10 ${ }^{\mathrm{a}}$ ed. Edinburgh: Churchill Livingstone, 2000. p. 515-526. 
GOLDSPINK, G. Cytological basis of decrease in muscle strength during starvation. Am. J. Physiol., v. 209, p. 100-104, 1965.

GOLDSPINK, G. The combined effects of exercise and reduced food intake on skeletal muscle fibres. J. Cell Comp. Physiol., v. 63, p. 209-216, 1964.

GOLDSTEIN, D.E.; CURNOW, R.T. Effect of starvation on hepatic glycogen metabolism and glucose homeostasis. Metabolism, v. 27, p. 315-323, 1978.

GOLLNICK, P.D.; PIEHL, K.; SALTIN, B. Selective glycogen depletion pattern in human muscle fibres of varying intensity and at varying pedalling rates. J. Physiol., v. 241, p.4557, 1974.

HAIGENHAUSER, G.J.; PAROLIN, M.L. Role of pyruvate dehydrogenase in lactate production in exercising human skeletal muscle. Adv. Exp. Med. Biol., v. 474, p. 205218, 1999.

HALL, J.E.; BRANDS, M.W.; DIXON, W.N.; SMITH Jr., M.J. Obesity-induced hypertension. Renal function and systemic homodynamic. Hypertension, v. 22, p. 292299, 1993.

HAMBRECHT, R.; FIEHN, E.; YU, J.; NIEBAUER, J.; WEIGL, C.; HILBRICH, L.; ADAMS, V.; RIEDE, U.; SCHULER, G. Effects of endurance training on mitochondrial ultrastructure and fiber type distribution in skeletal muscle of patients with stable chronic heart failure. J. Am. Coll. Cardiol., v. 29, p. 1067-1073.

HANSEN, D.; DENDALE, P.; BERGER, J.; van LOON, L.J.C.; MEEUSEN, R. The effects of exercise training on fat-mass loss in obese patients during energy intake restriction. Sports Med., v. 37, p. 31-46, 2007.

HARGREAVES, M. Skeletal muscle carbohydrate metabolism. In: HARGREAVES M. (Ed.). Exercise Metabolism. United States of America: Human Kinetics Publishers, 1995.

HARGREAVES, M.; KIENS, B.; RICHTER, E.A. Effect of plasma free fatty acid concentration on muscle metabolism in exercising men. J. Appl. Physiol., v. 70, p. 194210, 1991.

HASSID, W.Z.; ABRAHAMS, S. Chemical procedures for analyses of polysaccharides. Method. Enzimol., v. 3, p. 34-51, 1957.

HELGE, J.W.; KIENS, B. Muscle enzyme activity in humans: role of substrate availability and training. Am. J. Physiol. Regul. Integr. Comp. Physiol., v. 272, p. R1620-R1624, 1997.

HENRIKSSON, J. The possible role of skeletal muscle in the adaptation to periods of energy deficiency. Eur. J. Clin. Nutr., v. 44, p. 55-64, 1990.

HOLLOSZY, J.O.; BOOTH, F.W. Biochemical adaptations to endurance exercise in muscle. Annu. Rev. Physiol., v. 38, p. 273-291, 1976. 
HOLLOSZY, J.O.; OSCAI, L.B.; DON, I.J.; MOLE, P.A. Mitochondrial citric acid cycle and related enzymes: adaptative response to exercise. Biochem. Biophys. Res. Commun., v. 40, p. 1368-1373, 1970.

HOLMES, E.G.; JONES, E.R.; LYLE, M.D.; STAINER, M.W. Malnutrition in African adults: effect of diet on body composition. Brit. J. Nutr., v. 10, p. 198-219, 1956.

HOLNESS, M.J.; PRIESTMAN, D.A.; SUGDEN, M.C. Impact of protein restriction on the regulation of cardiac carnitine palmitoyltransferase by malonyl-CoA. J. Mol. Cell. Cardiol., v; 30, p. 1381-1390, 1998.

HOOD, D.A.; SALEEM, A. Exercise-induced mitochondrial biogenesis in skeletal muscle. Nutr. Metab. Cardiovasc. Dis., v. 17, p. 332-337, 2007.

HOPPELER, H.; BILLETER, R. Conditions for oxygen and substrate transport in muscles in exercising mammals. J. Exp. Biol., v. 160, p. 263-283, 1991.

HUANG, Y. Malnutrition in the critically ill. Nutrition, v. 17, p. 744-746, 2001.

IBRAHIMI, A.; BONEN, A.; BLINN, W.E.; HAJRI, T.; LI, X.; ZHONG, K.; CAMERON, R.; ABUMRAD, N.A. Muscle-specific overexpression of FAT/CD36 enhances fatty acid oxidation by contracting muscle, reduces plasma triglycerides and fatty acids, and increases plasma glucose and insulin. J. Biol. Chem. v. 274, p. 26761-26766, 1999.

JETTE, A.M.; BRANCH, L.G. The Framingham disability study: II. Physical disability among the aging. Am. J. Public. Health, v. 71, p. 1211-1216, 1981.

JOHANSEN, K.; MUNCH, O. The relationship between maximal oxygen uptake and glucose tolerance/insulin response ratio in normal young men. Horm. Metab. Res., v. 11, p. 424427, 1979.

KALTER, H.D.; GRAY, R.H.; BLACK, R.E.; GULTIANO, S.A. Validation of postmortem interviews to ascertain selected causes of death in children. Int. J. Epidemiol., v. 19, p. 380-386, 1990.

KATZ, A.; SAHLIN, K.; HENRIKSSON, J. Carbohydrate metabolism in human skeletal muscle during exercise is not regulated by G-1,6-P .. J. Appl. Physiol., v. 65, p. 487-489, 1988.

KEUSCH, G.T. The history of nutrition: malnutrition, infection and immunity. J. Nutr., v. 133, p. 336S-340S, 2003.

KRAEMER, W.J. Endocrine responses to resistance exercise. Med. Sci. Sports Exerc., v. 20, p. S152-S157, 1988.

KUOPPASALMI, K.; NAVERI, H.; HARKONEN, M.; ADLERCREUTZ, H. Plasma cortisol, androstenedione, testosterone and luteinizing hormone in running exercise of different intensities. Scand. J. Clin. Lab. Invest., v. 40, p. 403-409, 1980. 
KUOPPASALMI, K.; NAVERI, H.; REHUNEN, S.; HARKONEN, M.; ADLERCREUTZ, $\mathrm{H}$. Effect of strenuous anaerobic running exercise on plasmagrowth hormone, cortisol, luteinizing hormone, testosterone, androstenedione, estrone and estradiol. J. Steroid. Biochem., v. 7, p. 823-829, 1976.

LAMB, D.R.; BRODOWICZ, G.W. Optimal use of fluids of varying formulation to minimize exercise-induced disturbances in homeostasis. Sports Med., v.3, p. 247-274, 1986.

LANE, M.A.; BAER, D.J.; RUMPLER, W.V.; WEINDRUCH, R.; INGRAM, D.K.; TILMONT, E.M.; CUTLER, R.G.; ROTH, G.S. Calorie restriction lowers body temperature in rhesus monkeys, consistent with a postulated anti-aging mechanism in rodents. Proc. Natl. Acad. Sci. U.S.A., v. 93, p. 4159-4164, 1996.

LAPACHET, R.A.B.; MILLER, W.C.; ARNALL, D.A. Body fat and exercise endurance in trained rats adpted to a high-fat and/or high-carbohydrate diet. J. Appl. Physiol., v.80, p. 1173-1179, 1996.

LAYMAN D, K.; MERDIAN-BENDER, M.; HEGARTY, P.V.; SWAN, P.B. Changes in aerobic and anaerobic metabolism in rat cardiac and skeletal muscles after total or partial dietary restrictions. J. Nutr., v. 111, p. 994-1000, 1981.

LEBLANC, J.; NADEAU, A.; BOULAY, M.; ROUSSEAU-MIGNERON, S. Effects of physical training and adiposity on glucose metabolism and 125I-insulin binding. J. Appl. Physiol., v. 46, p. 235-239, 1979.

LEBLANC, J.; NADEAU, A.; RICHARD, D.; TREMBLAY, A. Studies on the sparing effect of exercise on insulin requirements in human subjects. Metabolism, v. 30, p. 1119-1124, 1981.

LEONARD, B.E.; SONG, C. Stress and the immune system in the etiology of anxiety and depression. Pharmacol. Biochem. Behav., v. 54, p. 299-303, 1996.

LEWIS, G.F.; CARPENTIER, A.; ADELI, K.; GIACCA, A. Disordered fat storage and mobilization in the pathogenesis of insulin resistance and type 2 diabetes. Endocr. Rev., v. 23, p. 201-229, 2002.

LEWIS, S.F.; HALLER, R.G. The pathophysiology of McArdle's disease: clues to regulation in exercise and fatigue. J. Appl. Physiol., v. 61, p. 391-401, 1986.

LI, J.B.; WASSNER, S.J. Effects of food deprivation and refeeding on total protein and actomyosin degradation. Am. J. Physiol., v. 246, p. E32-E37, 1984.

LOHMAN, D.; LIEBOLD, F.; HEILMANN, W.; SINGER, J.; POHL, A. Diminished insulin response in highly trained athletes. Metab. Clin. Exp., v. 27, p. 521-524, 1978.

LOWELL, B.B.; RUDERMAN, N.B.; GOODMAN, M.N. Regulation of myofibrillar protein degradation in rat skeletal muscle during brief and prolonged starvation. Metabolism, v. 35, p. 1121-1127, 1986. 
LOWRY, O.H.; ROSEBROUGH, N.J.; FARR, A.L.; RANDALL, R.J. Protein measurement with the Folin phenol reagent. J. Biol. Chem., v. 193, p. 265-275, 1951.

LYONS, T.P.; RIEDESEL, M.L.; MUELI, L.E.; CHICK, T.W. Effect of glycerol-induced hyperhydration prior to exercise in the heat on sweating and core temperature. Med. Sci. Sports Exerc., v. 22, p. 477-483, 1990.

MATECKI, S.; PY, G.; LAMBERT, K.; PEYREIGNE, C.; MERCIER, J.; PREFAUT, C.; RAMONATXO, M. Effect of prolonged undernutrition on rat diaphragm mitochondrial respiration. Am. J. Respir. Cell Mol. Biol., v. 26, p. 239-245, 2002.

MAUGHAN, R.; GLEESON, M.; GREENHAFF, P.L. Fisiologia e bioquímica do músculo esquelético e do exercício. In: MAUGHAN, R.; GLEESON, M.; GREENHAFF, P.L. (Ed.). Bioquímica do Exercício e do Treinamento. São Paulo: Manole, 2000.

MAXWELL, L.C.; ENWEMEKAT, C.S.; FERNANDES, G. Effect of exercise and food restriction on rat skeletal muscles. Tissue Cell, v. 24, p. 491-498, 1992.

McCARTY, M.F. Modulation of adipocyte lipoprotein lipase expression as a strategy for preventing or treating visceral obesity. Med. Hypotheses, v. 57, p. 192-200, 2001.

MCGARRY, J. D.; BROWN, N.F. The mitochondrial palmitoyltransferase system. From concept to molecular analysis. Eur. J. Biochem., v. 244, p. 1-14, 1997.

MIGLIORINI, R.H.; GAROFALO, M.A.; KETTELHUT, I.C. Increased sympathetic activity in rat white adipose tissue during prolonged fasting. Am. J. Physiol., v. 272, p. R651R656, 1997.

NATIO, H.; POWERS, S.K.; DEMIREL, H.A.; AOKI, J. Exercise training increases heat shock protein in skeletal muscles of old rats. Med. Sci. Sports Sci., v. 33, p. 729-734, 2001.

NESHER, R.; KARL, I.E.; KIPNIS, D.M. Dissociation of effects of insulin and contraction on glucose transport in rat epitrochlearis muscle. Am. J. Physiol., v. 249, p. C225-C232, 1985.

NOAKES, T.D. The limits of endurance exercise. Basic. Res. Cardiol., v. 101, p. 408-417, 2006.

OGURI, K.; ZHAO, L.; DuU, N.; KATO, Y.; MIYAMOTO, K.; HAYAKAWM, M.; KUROKAWA, J.; NAGASAKI, S.; MATSUOKA, T. Association of habitual longdistance running with the thickness of skeletal muscles and subcutaneous fat in the body extremities and trunk in middle-agedmen. J. Sports Med. Phys. Fitness, v. 44, p. 417423, 2004.

OWENS, F.N.; DUBESKI, P.; HANSON, C.F. Factors that alter the growth and development of ruminants. J.Anim. Sci., v. 71, p. 3138-3150, 1993. 
PETTIGREW, R.A.; CHARLESWORTH, P.M.; FARMILO, L.W. Assessment of nutritional depletion and immune competence: a comparison of clinical examination and objective measurements. JPEN J. Parenter. Enteral Nutr., v. 8, p. 21-24, 1984.

PICHARD, C.; VAUGHAN, C.; STRUK, R.; ARMSTRONG, R.L.; JEEJEEBHOY, K.N. Effect of dietary manipulations (fasting, hypocaloric feeding, and subsequent refeeding) on rat muscle energetic assessed by nuclear magnetic resonance spectroscopy. J. Clin. Invest., v. 82, p. 895-901, 1988.

PLOUG, T.; GALBO, H.; OHKUWA, T.; TRANUM-JENSEN, J.; VINTEN, J. Kinectics of glucose transport in rat skeletal muscle membrane vesicles: effects of insulin and contractions. Am. J. Physiol., v. 262, p. E700-E711, 1992.

PLOUG, T.; GALBO, H.; VINTEN, J.; JORGENSEN, M.; RICHTER, E.A. Kinectics of glucose transport in rat skeletal muscle: effects of insulin and contractions. Am. J. Physiol., v. 253, p. E12-E20, 1987.

RAPPAPORT, E.B.; YOUNG, J.B.; LANDSBERG, L. Initiation, duration and dissipation of diet-induced changes in sympathetic nervous system activity in the rat. Metabolism, v. 31, p. 143-146, 1982.

REITMAN, J.S.; HENRIKSSON, J. Quantitative measures of enzyme activities in type I and type II muscle fibres of man after training. Acta Physiol. Scand., v. 97, p. 392-397, 1976.

RICHTER, E.A.; SUTTON, J.R. Hormonal adaptation to physical activity. In: BOUCHARD, C.; SHEPARD, R.J.; STEPHENS, T. Physical Activity, Fitness, and Health. Champaign: Human Kinetics Publishers, 1994.

ROSS, R.; FREEMAN, J.; JANSSEN, I. Exercise alone is an effective strategy for reducing obesity and related comorbidities. Exerc. Sport Sci. Rev., v. 28, p. 165-170, 2000.

ROSS, R.; JANSSEN, I.; DAWSON, J.; KUNGL, A.; KUK, J.; WONG, S.; NGUYEN-DUY, T.; LEE, S.; KILPATRICK, K.; HUDSON, R. Exercise-induced reduction in obesity and insulin resistance in women: randomized controlled trial. Obes. Res., v. 12, p. 789-798, 2004.

RUBENSTEIN, L.Z. Falls in the elderly. A clinical approach. West. J. Med., v. 138, p. 273275, 1983.

RUSSEL, D.McR.; ATWOOD, H.L.; WHITTAKER, J.S.; ITAKURA, T.; WALKER, P.M.; MICKLE, D.A.G.; JEEJEEBHOY, K.N. The effect of fasting and hypocaloric diets on the functional and metabolic characteristics of rat gastrocnemius muscle. Clin. Sci., v. 67, p. 185-194, 1984b.

RUSSEL, D.McR.; WALKER, P.M.; LEITER, L.A; SIMA, A.A.F.; TANNER, W.K.; MICKLE, D.A.G.; WHITWELL, J.; MARLISS, E.B.; JEEJEEBHOY, K.N. Metabolic and structural changes in skeletal muscle during hypocaloric dieting. Am. J. Clin. Nutr., v. 39, p. 503-513, 1984a. 
RYU, M.H.; DAILY, J.W. $3^{\text {rd }}$; CHA, Y.S. Effect of starvation on hepatic acyl-CoA synthetase, carnitine palmitoyltransferase-I, and acetyl-CoA carboxylase mRNA levels in rats. Nutrition, v. 21, p. 537-542, 2005.

SAHLIN, K.; KATZ, A.; BROBERG, S. Tricarboxilic acid cycle intermediates in human muscle during prolonged exercise. Am. J. Physiol., v. 259, p. C834-C841, 1990.

SAITOH, S.; MATSUO, T.; TAGAMI, K.; CHANG, K.; TOKUYAMA, K.; SUZUKI, M. Effects of short-term dietary change from fat to high carbohydrate diets on the storage and utilization of glycogen and triacylglycerol in untrained rats. Eur. J. Appl. Physiol., v. 73, p. 13-22, 1996.

SALWAY, J.G. Metabolism of glucose to glycogen. In: SALWAY, J.G. (Ed.). Metabolism at a glance. $3^{\mathrm{a}}$ ed. Oxford: Blackwell Publishing, 2004a.

SALWAY, J.G. The ketone bodies. In: SALWAY, J.G. (Ed.). Metabolism at a glance. $3^{\mathrm{a}}$ ed. Oxford: Blackwell Publishing, 2004b.

SAMBROOK, J.; FRITSH, E.F.; MANIATIS, T. Molecular cloning: a laboratory manual. $2^{\text {a. }}$ ed. New york: Cold Spring Habour Laboratory Press, 1989.

SANCHEZ, J.; BASTIEN, C.; MONOD, H. Enzymatic adaptations to treadmill training in skeletal muscle of young and old rats. Eur. J. Appl. Physiol., v. 52, p. 69-74, 1983.

SARIS, W.H. Effects of energy restriction and exercise on the sympathetic nervous system. Int. J. Obes. Relat. Metab. Disord., v. 19, p. S17-S23, 1995.

SCHOFIELD, C.; ASHWORTH, A. Why have mortality rates for severe malnutrition remained so high? Bull. World Health Organ., v. 74, p. 223-229, 1996.

SEALS, D.R.; HAGBERG, J.M.; ALLEN, W.K.; HURLEY, B.F.; DALSKY, G.P.; EHSANI, A.A.; HOLLOSZY, J.O. Glucose tolerance in young and older athletes and sedentary men. J. Appl. Physiol., v. 56, p. 1521-1525, 1984.

SHEPHARD, R.J. Determinants of endurance performance. In: SHEPARD R.J.; ASTRAND P.-O. (Ed.). Endurance in sport. $2^{\mathrm{a}}$ ed. Oxford: Blacwell Science, 2000.

SHETTY, P.S. Adaptive changes in basal metabolic rate and lean body mass in chronic undernutrition. Hum. Nutr. Clin. Nutr. v. 38, p. 573-581, 1984.

SJÖRGREEN, B.; NORDENKSJÖLD, T.; HOLMGREN, H.; WÖLLERSTRON, J. Beitrag zur kentnis des lebenrhythmik. Pflügers Arch Gesante Physiol Menschen Tiere. 240 247, 1938.

SLENTZ, C.A.; DAVIS, J.M.; SETTLES, D.L.; PATE, R.R.; SETTLES, S.J. Glucose feedings and exercise in rats: glycogen use, hormone responses, and performance. $\mathbf{J}$. Appl. Physiol., v. 69, p. 989-994, 1990.

SOARES, M.J.; SHETTY, P.S. Basal metabolic rates and metabolic efficiency in chronic undernutrition. Eur. J. Clin. Nutr., v. 45, p. 363-373, 1991. 
SPENCER, M.K.; YAN, Z.; KATZ, A. Effect of low glycogen on carbohydrate and energy metabolism in human muscle during exercise. Am. J. Physiol., v. 262, p. C975-C979, 1992.

SPENCER, M.K.; YAN, Z.; KATZ, A. Carbohydrate supplementation attenuates IMP accumulation in human muscle during prolonged exercise. Am. J. Physiol., v. 261, p. C71-C76, 1991.

SPINA, R.J.; CHI, M.M.; HOPKINS, M.G.; NEMETH, P.M.; LOWRY, O.H.; HOLLOSZY, J.O. Mitochondrial enzymes increase in muscle in response to 7-10 days of cycle exercise. J. Appl. Physiol., v. 80, p.2250-2254, 1996.

SPRIET, L.L. Phosphofructokinase activity and acidosis during short-term titanic contractions. Can. J. Physiol. Pharmacol., v. 69, p. 298-304, 1991.

SPRIET, L.L.; HAIGENHAUSER, G.J. Regulation of pyruvate dehydrogenase (PDH) activity in human skeletal muscle during exercise. Exerc. Sport. Sci. Rev., v. 30, p. 9195, 2002.

SPRIET, L.L.; HOWLETT, R.A.; HEIGENHAUSER, G.J. An enzymatic approach to lactate production in human skeletal muscle during exercise. Med. Sci. Sports Exerc., v. 32, p. 756-763, 2000.

SPRIET, L.L.; HOWLETT, R.A. Metabolic control of energy production during physical activity. In: LAMB, D.R.; MURRAY, R. (Ed.). The metabolic basis of performance in exercise and sport. United States of America: Cooper Publishing Group, 1999.

SPURR, G.B.; BARAC-NIETO, M.; REINA, J.C.; ROMELIA RAMIREZ, M.S. Marginal malnutrition in school-aged Colombian boys: efficiency of treadmill walking in submaximal exercise. Am. J. Clin. Nutr., v. 39, p. 452-459, 1984.

SPURR, G.B.; REINA, J.C.; BARAC-NIETO, M. Marginal malnutrition in school-aged Colombian boys: anthropometry and maturation. Am. J. Clin. Nutr. v. 37, p. 119-132, 1983.

SPURR, G.B.; REINA, J.C.; DAHNERS, H.W.; BARAC-NIETO, M. Marginal malnutrition in school-aged Colombian boys: functional consequences in maximum exercise. Am. $\mathbf{J}$. Clin. Nutr., v. 37, p. 834-847, 1983.

STALLKNECHT, B.; VISSING, J.; GALBO, H. Lactate production and clearance in exercise. Effects of training. A mini-review. Scand. J. Med. Sci. Sports, v. 8, p. 127-131, 1998.

STANLEY, W.C.; CONNETT, R.J. Regulation of muscle carbohydrate metabolism during exercise. FASEB J., v. 5, p. 2155-2159, 1991.

STANLEY, W.C.; GERTZ, E.W.; WISNESKI, J.A.; MORRIS, D.L.; NEESE, R.; BROOKS, G.A. Lactate metabolism in exercising human skeletal muscle: evidence for lactate extraction during net lactate release. J. Appl. Physiol., v. 60, p. 1116-1120, 1986. 
STANSBIE, D.; BROWNSEY, R. W.; CRETTAZ, M.; DENTON, R. M. Accute effects in vivo of anti-insulin serum on rates of fatty acids synthesis and activities of acetylCoenzyme A carboxylase and pyruvate dehydrogenase in liver and epididymal adipose tissue of fed rats. Biochem. J., v. 160, p. 413-416, 1976.

SUTTER, E.; HOPPELER, H.; CLAASSEN, H.; BILLETER, R.; AEBI, U.; HORBER, F.; JAEGER, P.; MARTI, B. Ultrastructural modification of human skeletal muscle tissue with 6-month moderate-intensity exercise training. Int. J. Sports Med., v. 16, p. 160-166, 1995.

TERJUNG, R.L.; DUDLEY, G.A.; MEYER, R.A. Metabolic and circulatory limitations to muscular performance at the organ level. J. Exp. Biol., v. 115, p. 307-318, 1985.

TORUN, B.; CHEW, F. Protein-energy malnutrition. In: SHILS, M.E.; OLSON, J.A.; SHIKE, M.; ROSS, A.C. Modern nutrition in health and disease. 9 $9^{\mathrm{a}}$ ed. Baltimore: Williams \& Wilikins, 1999.

TREMBLAY, M.S.; CHU, S.Y. Hormonal response to exercise. In: WARREN, M.P.; CONSTANTINI, N.W. Sports Endocrinology. New Jersey: Humana Press, 2000.

TURCOTTE, L.P.; RICHTER, E.A.; KIENS, B. Lipid metabolism during exercise. In: HARGREAVES, M. Exercise metabolism. $1^{\text {a }}$ ed. United States of America: Human: Kinectics Publishers, 1995.

UNICEF - United Nations Children's Fund. Child mortality statistics. Disponível em: http://www.childinfo.org/cmr/revis/db2.htm . Acesso em: 10 out. 2007.

WADE, G.N.; SCHNEIDER, J.E.; LI, H.Y. Control of fertility by metabolic cues. Am. J. Physiol., v. 270, p. E1-E19, 1996.

WALLBERG-HENRIKSSON, H.; CONSTABLE, S.H.; YOUNG, D.A.; HOLLOSZY, J.O. Glucose transport into rat skeletal muscle: interaction between exercise and insulin. $\mathbf{J}$. Appl. Physiol., v. 65, p. 909-913, 1988.

WASSERMAN, D.H.; CONNOLLY, C.C.; PAGLIASSOTTI, M.J. Regulation of hepatic lactate balance during exercise. Med. Sci. Sports Exerc., v. 23, p. 912-919, 1991.

WESTON, A.R.; KARAMIZRAK, O.; SMITH, A.; NOAKES, T.D.; MYBURGH, K.H. African runners exhibit greater fatigue resistance, lower lactate accumulation, and higher oxidative enzyme activity. J. Appl. Physiol., v. 86, p. 915-923, 1999.

WHITLOCK, D.M.; TERJUNG, R.L. ATP depletion in slow-twich red muscle of rat. Am. J. Physiol., v. 253, p. C426-C432, 1987.

WHO - World Health Organization. Protein-energy malnutrition. Disponível em: http://www.wpro.who.int/health_topics/protein_energy/. Acesso em: 10 out. 2007. 
WINICK, M. Hunger disease - studies by the Jewish physicians in the Warsaw Ghetto. New York: John Willey \& Sons, 1997, p. 1-242.

WOODS, S.C.; SEELEY, R.J.; PORTE Jr., D.; SCHWARTZ, M.W. Signals that regulate food intake and energy homeostasis. Science, v. 280, p. 1378-1383, 1998.

YOON, J.; PARK, S. Exercise intensity-related responses of $\beta$-endorphin, ACTH, and cortisol. Korean J. Sport Sci., v. 3, p. 21-32, 1991.

YOUNG, J.B.; LANDSBERG, L. Suppression of sympathetic nervous system during fasting. Science, v. 196, p. 1473-1475, 1977.

YOUNG, J.B.; MULLIN, D.; LANDSBERG, L. Caloric restriction lowers blood pressure in the spontaneously hypertensive rat. Metabolism, v. 27, p. 1711-1714, 1978. 